\title{
Bibliografia historii wychowania, szkolnictwa i myśli pedagogicznej w Polsce za rok 2006 (z uzupelnieniami za lata poprzednie)
}

Bibliografia rejestruje druki zwarte, artykuły z czasopism i prac zbiorowych, wydane w 2006 roku oraz uzupełnienia do poprzednich części bibliografii, publikowanych na łamach Biuletynu Historii Wychowania od 2002 roku. Ma układ według podanego niżej schematu. W poszczególnych działach i poddziałach (z wyjątkiem poddziału 5. Szkoły wyższe w Dziale III, gdzie zastosowano układ według nazw szkół oraz poddziału 2. Poszczególne biografie w Dziale IV, w którym pozycje ułożone zostały według nazwisk osób) zastosowano układ alfabetyczny według haseł autorskich lub tytułowych. Opisy w razie potrzeby uzupełniono adnotacjami, a w przypadku prac zbiorowych wyszczególniono składające się na nie artykuły, dotyczące historii oświaty i wychowania.

I. Opracowania ogólne. Bibliografie

II. Rozwój oświaty, wychowania i myśli pedagogicznej

1. Opracowania ogólne

2. Okres do 1795 roku

3. Okres $1795-1918$

4. Okres 1918-1939

5. Okres 1939-1945

6. Okres 1945-1989

7. Okres 1989-2006

8. Oświata polonijna

III. Dzieje szkół różnych stopni

1. Szkoły podstawowe i zakłady wychowawcze

2. Szkoły średnie ogólnokształcące

3. Szkoły zawodowe

4. Zakłady kształcenia nauczycieli (z wyjątkiem szkół wyższych)

5. Szkoły wyższe

IV. Bibliografie

1. Zbiory życiorysów

2. Poszczególne biografie

V. Dzieje oświaty pozaszkolnej

1. Oświata dorosłych

2. Biblioteki

VI. Dzieje ruchu nauczycielskiego

1. Opracowania ogólne i monografie

2. Pamiętniki nauczycieli

VII. Organizacje młodzieżowe 


\section{Wykaz skrótów czasopism}

Acta Univ. Wr. - Acta Universitatis Wratislaviensis

Almanach Hist. - Almanach Historyczny

Annales APC - Annales Academiae Paedagogicae Cracoviensis

Arch. Emigracji - Archiwum Emigracji

Arch. Hist. i Filoz. Med. - Archiwum Historii i Filozofii Medycyny

Arch. Pol. - Archiwista Polski

Białorus. Zesz. Hist. - Białoruskie Zeszyty Historyczne

Biul. Hist. - Biuletyn Historyczny. Lęborskie Bractwo Historyczne

Biul. IPN - Biuletyn Instytutu Pamięci Narodowej

Dzieje Najn. - Dzieje Najnowsze

Krak. Rocz. Archiw. - Krakowski Rocznik Archiwalny

Krak. Studia Małop. - Krakowskie Studia Małopolskie

Kron. Bydg. - Kronika Bydgoska

Kron. Szczec. - Kronika Szczecińska

Kutn. Zesz. Region. - Kutnowskie Zeszyty Regionalne

Kw. Hist. Nauki i Techn. - Kwartalnik Historii Nauki i Techniki

Lub. Rocz. Pedag. - Lubelski Rocznik Pedagogiczny

Maz. Studia Hum. - Mazowieckie Studia Humanistyczne

Mrąg. Studia Hum. - Mrągowskie Studia Humanistyczne

Nadwarc. Rocz. Hist.-Archiw. - Nadwarciański Rocznik Historyczno-Archiwalny

Nauka Pol. - Potrz. Org. - Nauka Polska - Jej Potrzeby, Organizacja i Rozwój

Niepodl. i Pam. - Niepodległość i Pamięć

Pam. i Sprawiedl. - Pamięć i Sprawiedliwość

Piotrk. Studia Pedagog. - Piotrkowskie Studia Pedagogiczne

Piotrk. Zesz. Hist. - Piotrkowskie Zeszyty Historyczne

Pr. Kom. Hist. Nauki - Prace Komisji Historii Nauki

Pr. Uczestników Studium Doktor. - Prace Uczestników Seminarium Doktoranckiego

Prz. Hist.-Ośw. - Przegląd Historyczno-Oświatowy

Prz. Hum. - Przegląd Humanistyczny

Prz. Wsch. - Przegląd Wschodni

Prz. Zach. - Przegląd Zachodni

Rocz. Bibliot. - Roczniki Biblioteczne

Rocz. Elbl. - Rocznik Elbląski

Rocz. Gdań. - Rocznik Gdański

Rocz. Hist.-Archiw. - Rocznik Historyczno-Archiwalny

Rocz. Hist. Harcerstwa - Rocznik Historii Harcerstwa

Rocz. Hist. MHPRL - Rocznik Historyczny Muzeum Historycznego Polskiego Ruchu Ludowego

Rocz. Hum. - Roczniki Humanistyczne

Rocz. Kalis. - Rocznik Kaliski

Rocz. Kom. Nauk Pedag. - Rocznik Komisji Nauk Pedagogicznych

Rocz. Krak. - Rocznik Krakowski

Rocz. Legion. - Rocznik Legionowski

Rocz. Lud. Tow. Nauk.-Kult. Oddz. w Krakowie - Rocznik Ludowego Towarzystwa Naukowo-Kulturalnego Oddział w Krakowie

Rocz. Lwow. - Rocznik Lwowski

Rocz. Miel. - Rocznik Mielecki 
Rocz. Muz. Nar w Kielcach - Rocznik Muzeum Narodowego w Kielcach

Rocz. Nauk. $A W F$ - Rocznik Naukowy Akademii Wychowania Fizycznego

Rocz. Pedag. - Rocznik Pedagogiczny

Rocz. Przem. - Rocznik Przemyski

Rocz. Sqdec. - Rocznik Sądecki

Rocz. Stow. Mitośn. Jarosławia - Rocznik Stowarzyszenia Miłośników Jarosławia

Rocz. Teol. - Roczniki Teologiczne

Rocz. Wołom. - Rocznik Wołomiński

Rocz. Wsch. - Rocznik Wschodni

Studenckie Teki Hist. - Studenckie Zapiski Historyczne

Studia Elbl. - Studia Elbląskie

Studia Franciszk. - Studia Franciszkańskie

Studia i Mater. do Dz. Pow. Wolom. - Studia i Materiały do Dziejów Powiatu Wołomińskiego

Studia Podl. - Studia Podlaskie

Studia z Dz. Rosji i Europy Środk -Wsch. - Studia z Dziejów Rosji i Europy Środkowo-Wschodniej

Śl. Kw. Hist. Sobótka - Śląski Kwartalnik Historyczny Sobótka

Wiad. Num. - Wiadomości Numizmatyczne

Wiad. Statyst. - Wiadomości Statystyczne

Zap. Kuj.-Dobrz. - Zapiski Kujawsko-Dobrzyńskie

Zbliż. Pol.-Niem. - Zbliżenia. Polska-Niemcy

Zesz. Hist. Politech. Eódz. - Zeszyty Historyczne Politechniki Lódzkiej

Zesz. Hist.-Teol. - Zeszyty Historyczno-Teologiczne

Zesz. Nauk. UJ-Zeszyty Naukowe Uniwersytetu Jagiellońskiego

Zesz. Nauk. Uniw. Rzesz. - Zeszyty Naukowe Uniwersytetu Rzeszowskiego

Zesz. Sandom. - Zeszyty Sandomierskie

Ziemia Dobrz. - Ziemia Dobrzyńska

Ziemia Kuj. - Ziemia Kujawska

Ziemia Prudn. - Ziema Prudnicka 


\section{OPRACOWANIA OGÓLNE. BIBLIOGRAFIE}

1. ANDRYSIAK Ewa: Źródła i materiały do dziejów szkolnictwa handlowego i ekonomicznego w Kaliszu. Rocz. Kalis. T. 32: 2006 s. 235-246.

Przegląd publikowanych i niepublikowanych materiałów.

2. CICHOSZ Mariusz: Pedagogika społeczna w Polsce w latach 1945-2005. Rozwój, obszary refleksji, koncepcje. Toruń 2006 Adam Marszałek ss. 294, nlb. 2.

3. DAJNOWICZ Małgorzata: $Z$ badań nad oświatą guberni łomżyńskiej. Polszczyzna miast i miasteczek. Nazewnictwo miejskie. Pod red. Henryki Sędziak. Łomża 2006 s. 219-227.

4. FRANASZEK Anna: Od Bieruta do Herlinga-Grudzińskiego. Wykaz lektur szkolnych w Polsce w latach 1946-1999. Warszawa 2006 BN ss. 439, nbl. 1. Inst. Książki i Czytelnictwa.

5. GRATKOWSKI Henryk: Krasiński w podręcznikach szkolnych. Zarys. Jelenia Góra 2006 Kolegium Karkonoskie ss. 177, il. Kolegium Karkonoskie Państwowa Wyższa Szkoła Zawodowa.

6. JAZDON Krystyna: Oświata. Pismo sześciotygodniowe, poświęcone domowemu i szkolnemu wychowaniu 1865-1867. Poznań 2001 UAM ss. nlb. 2, 25, il. (Spis Zawartości Prasy Wielkopolskiej; z. 17).

7. KUKLA Wiesław, Miszczuk Marian: Bibliografia harcerskich emigracyjnych i polonijnych druków zwartych, jednodniówek, kalendarzy i miscellaneów wydawanych w latach 1912-2004. Warszawa 2006 Tomiko ss. 178, nlb. 1, sum. (Dzieje Harcerskich Wydawnictw Polonijnych i Emigracyjnych; t. 4).

8. KWIECIŃSKA Roma, Kowal Stanisław: Nauczyciel - tożsamość - rozwój. Konferencja zorganizowana przez Instytut Nauk o Wychowaniu Akademii Pedagogicznej im. Komisji Edukacji Narodowej. Kraków, 8-9.12.2005. Rocz. Pedag. T. 29: 2006 s. 101-105.

9. LITAK Stanisław: Historia wychowania. T. 1: Do Wielkiej Rewolucji Francuskiej. Kraków 2004 Wydaw. WAM; WSF-P „Ignatianum” ss. 244, il., mapy.

Toż. Wyd. 2 popr. i uzup. Kraków 2005 ss. 256, il., mapy.

Rec. [wyd. 1]: Markiewiczowa Hanna, Prz. Hist.-Ośw. R. 49: 2006 nr 1/2 s. 161-163.

10. MEISSNER Andrzej: Towarzystwo Historii Edukacji. Zesz. Nauk. Uniw. Rzesz. Nr 24: Ser. Pedagog.: Pedagogika i Psychologia. [Z.] 2: 2004 s. 261-262.

Powstało w Pułtusku 24 II 2000 r.; oddział rzeszowski w 2003 r.

11. OGÓLNOPOLSKI Klub Autorów i Dokumentalistów opracowań historii harcerstwa w latach 1956-2000. Warszawa 2002 „Paleta-Art” R. Paszkowski; Ogólnopolski Klub Autorów i Dokumentalistów Historii Harcerstwa „Gniezno" ss. 28, il.

Bibliografia adnotowana.

12. POLSKIE badania nad myślą pedagogiczną w latach 1900-1939. Parerga. Oprac. Sławomir Sztobryn i Małgorzata Świtka. Gdańsk 2006 Gdańskie Wydaw. Psychologiczne ss. 502. (Szkice, Rozprawy, Studia) (Pedagogika).

Z treści: Sztobryn S.: Wstęp s. 7-20; Truchim Stefan: Historia doktryn pedagogicznych a historia szkolnictwa s. 21-27; Królińska Janina: Poglądy pedagogiczne w literaturze polskiej XVII wieku s. 257-275; Wąsik Wiktor: Zagadnienie wartości kultury w Polsce wieku Oświecenia s. 287-312. 
13. SKOCZYLAS-KROTLA Edyta: Znaczenie ,Życia Szkoły” w podnoszeniu wiedzy lingwistycznej nauczycieli. Piotrk. Studia Pedag. T. 12: 2006 s. 147-151.

Wychodzi od $1946 \mathrm{r}$.

14. SOCHA Irena: Druki ulotne i okolicznościowe jako świadectwa kultury szkoły. [W:] Druki ulotne i okolicznościowe - wartości i funkcje. Materiały międzynarodowej konferencji naukowej Wojnowice, 8-10 października 2004. Red. nauk. Krzysztof Migoń, Marta Skalska-Zlat, Anna Żbikowska Migoń przy współpr. Elżbiety Herden. Wrocław 2006 s. 322-341.

15. STAREGO Karolina: Kondycja pedagogiki - dzisiaj. Kontynuacje, inspiracje i wyzwania pedagogiczne z perspektywy gdańskiej. Gdańsk, 6-7.06.2005. Rocz. Pedag. T. 29: 2006 s. 83-90.

16. WIECZOREK Barbara: Bibliografia pedagogiki 2004 (książki wydane w Polsce: wybór). Rocz. Pedag. T. 29: 2006 s. 209-219.

17. WOLTER Edyta: Historyczne aspekty edukacji ekologicznej w Polsce. Warszawa 2006 Wydaw. Uniw. Kard. Stefana Wyszyńskiego ss. 298.

18. ZASZTOWT Leszek: Prace z zakresu dziejów oświaty i wychowania na łamach „Kwartalnika Historii Nauki i Techniki”. Kw. Hist. Nauki i Techn. R. 51: 2006 nr 1 s. 67-81, sum.

\section{ROZWÓJ OŚWIATY, WYCHOWANIA I MYŚLI PEDAGOGICZNEJ}

\section{Opracowania ogólne}

19. ANTHOLOGY of social and behavioural sciences. 20 years of co-operation between the Universities in Linköping and Gdańsk. Ed. by Tomasz Maliszewski, Wit J. Wojtowicz, Józef Żerko. Linköping-Gdańsk 2005 Linkôping Univ.; Univ. of Gdańsk ss. 507, il.

$\mathrm{Z}$ treści: Wojtowicz W. J.: Co-operation between the University in Linkn̆ping and the University of Gdańsk in the years 1984-2004: conditions, objectives and realization s. 19-27; Żerko J.: On the co-operation between University of Gdańsk and University in Linkn̆ping (1984-2004) s. 28-38; Mokrzecki Lech: Lutheran Gymnasii Academici of Royal Prussia from the 16th to 18th centuries s. 39-49; Maliszewski T.: Two unknown Swedish episodes - a contribution to the history of Polish folk high school abroad s. 173-178; Ejsmont Marek: Educational and animating functions of children's and youth press s. 273-281.

20. ATAMAŃCZUK Kazimiera: Szkolnictwo elbląskie w latach 1945-2005. Rocz. Elbl. [T. 20]: 2006 s. 185-204.

21. AUSZ Mariusz: Szkoły pijarskie na Lubelszczyźnie w wiekach XVII-XIX. Lublin 2006 Wydaw. UMCS ss. 214.

22. BIELAWNY Krzysztof: Sieć szkół na terenie parafii ewangelickich w Nawiadach, Pieckach i w Starej Ukcie do 1945 r. Studia Elbl. T. 6: 2004/2005 [dr.:] 2005 s. 49-71, res.

Od XIII w.

23. BRUZIEWICZ-MIKLASZEWSKA Barbara: Zarys dziejów uniwersyteckiej stomatologii we Wrocławiu od renesansu do współczesności. Wrocław 2006 Akad. Medyczna ss. 201, sum. Akad. Medyczna we Wrocławiu. 
24. BRZUSZEK Bogdan: Papieskie Ateneum Antonianum w Rzymie Uniwersytetem Papieskim. Studia Franciszk. T. 16: 2006 s. 125-170, riass.

W aneksie: Polacy na rzecz Papieskiego Uniwersytetu Antonianum w XIX-XX w.

25. CHOŁUJ Henryk: Oświata w powiecie zwoleńskim w latach 1954-2005. [W:] Ziemia Jana Kochanowskiego. Powiat zwoleński. Pod red. Henryka Bednarczyka, Bogusławy Jaworskiej, Jerzego Kozińskiego. Sycyna-Radom 2006 s. 132-137.

26. DROBKIEWICZ Edwin: Szkolnictwo zawodowe. [W:] Z dziejów Lasów Państwowych i leśnictwa polskiego 1924-2004. T. 1: Okres międzywojenny. Red. nauk. t. 1 Jerzy Wiśniewski. Warszawa 2006 s. $125-144$.

27. FARUGA Andrzej: $Z$ kart historii szkolnictwa rolniczego bydgosko-cieszyńsko-olsztyńskiego. [W:] Stosunki polsko-czesko-słowackie 1918-2005. Pod red. Janusza Gmitruka i Andrzeja Stawarza. Warszawa 2006 s. 257-264.

28. JUSIAK Roman Oktawian: Społeczno-pedagogiczna aktywność bernardynów w XX wieku. [W:] Pięćset pięćdziesiąt lat obecności oo. Bernardynów w Polsce (1453-2003). Pod red. Wiesława F. Murawca, Damiana A. Muskusa. Kalwaria Zebrzydowska-Kraków 2006 s. 337-376.

29. KARDYŚ Piotr: Przywilej kruszwicki i prawa Luksemburgów do korony polskiej; dwa przykłady różnej interpretacji faktów historycznych i ich przekaz w nauczaniu historii. Prz. Hist.-Ośw. R. 49: 2006 nr 1/2 s. 117-127.

PRL i III RP.

30. KORZENIOWSKA Anna: Rozwój elbląskiego szkolnictwa i edukacji w latach 1945-2005. Rocz. Elbl. [T. 20]: 2006 s. 205-231.

31. KOZERA Andrzej: Źródła myśli oświatowej ruchu ludowego. [W:] Człowiek w świecie kultury, języka, edukacji. Praca zbiorowa. Pod red. Danuty Pluty-Wojciechowskiej, Witolda Adamczyka. Bielsko-Biała 2006 s. 419-429.

32. KRUPA Andrzej B.: Nauczanie religii na terenie parafii sztumskich w latach 1945-2000. Studia Elbl. T. 4: 2002 s. 91-133, Zsfg.

33. KUZAN Nadija: Žễnoča fahova osvếta na teritorě d' Schědnod' Galičini (XIX st. - 1939 r.). Lub. Rocz. Pedag. T. 25: 2005 s. 215-222.

34. LEŚ-RUDNICKA Maria: Historia szkolnej edukacji w Jaworznie do 1945 roku. Jaworzno 2004 Muzeum M. Jaworzna ss. 240, il.

XIX-XX w.

35. LIETZ Natalia: Międzynarodowa Konferencja „Koncepcje uniwersytetu w Polsce XIV-XXI w. W hołdzie Stanisławowi Staszicowi” zorganizowana z okazji zakończenia Roku Staszica. (19-20. 01.2006 roku w Warszawie i Pułtusku). Kw. Hist. Nauki i Techn. R. 51: 2006 nr 3/4 s. $365-371$.

36. LISSOWSKI Czesław: Prace zebrane. Teksty zebr. i do dr. przygot. Marek Błaszkiewicz, Piotr Gałkowski. Rypin 2004 Rypińskie Koło PTH; Starostwo Pow. ss. 327, nlb. 1, il.

Wyd. z okazji nadania Zespołowi Szkół nr 1 w Rypinie imienia ks. Cz. Lissowskiego, w dniu 15 XI 2004 r.

Z treści: Zlot Katolickiego Stowarzyszenia Młodzieży Żénskiej w Rypinie [1937 r.] s. 71-72; Kronika 7-klasowej Publicznej Szkoły Powszechnej Nr 2 w Rypinie, dawniej 7-klasowej Publicznej Szkoły Żeńskiej [z 1. 1885-1935] s. 275-295. 
Rec.: Szczechowicz Hanna, Zapiski Kujawsko-Dobrzyńskie. T. 20: 2005 s. 199-201; Żuchowski Zbigniew, Ziemia Dobrz. R. 10: 2006 s. 285-286.

37. MAGISTERSKIE studia $\mathrm{z}$ wychowania fizycznego w Szczecinie (1975-2005). Pod red. Jerzego Eidera. Szczecin 2006 Wydaw. Nauk. Uniw. Szczecińskiego ss. 193, il, sum. Uniw. Szczeciński. (Rozprawy i Studia; t. (691) 617).

Z treści: Eider J.: Wstęp s. 7-8; Toż w jęz. ang. s. 9-10; Laskiewicz Henryk: Historia studiów wychowania fizycznego w Szczecinie s. 11-30; Eider Pawel, Drohomirecka Alicja, Cięszczyk Paweł: Nauczyciele akademiccy Instytutu Kultury Fizycznej Uniwersytetu Szczecińskiego s. 41-50; Jaszczanin Jan: Nauczyciel akademicki prof. dr hab. Tadeusz Mieczkowski - animator kultury fizycznej s. 51-57; Lyskawa Marek: Człowiek dobrej roboty - Profesor Henryk Laskiewicz s. 59-64; Drohomirecka A.: Prace Wydziału Wychowania Fizycznego Wyższej Szkoły Pedagogicznej i Instytutu Kultury Fizycznej Uniwersytetu Szczecińskiego w „Zeszytach Naukowych" s. 109-115; Eider J.: Olimpijczycy - absolwentami magisterskich studiów z wychowania fizycznego w Szczecinie s. 117-128; Stefanik Ryszard: Kariery sportowe studentów Instytutu Kultury Fizycznej Uniwersytetu Szczecińskiego s. 129-147; Eider J., Eider P.: Wykaz absolwentów, którzy obronili prace magisterskie z wychowania fizycznego w Szczecinie w latach 1975-2005 s. 175-191.

38. MARKIEWICZOWA Hanna: Wybrane zagadnienia $\mathrm{z}$ historii wychowania. [Cz. 1]. Wyd. 2 zm. Warszawa 2006 Wydaw. Akad. Pedagogiki Specjalnej im. Marii Grzegorzewskiej ss. 108.

Podręcznik akademicki; Autor cz. 2: Poznański Karol; Wyd. 1. 2003.

39. MLŁOSZ Henryk: Szkolnictwo wyższe w Elblągu w latach 1954-2005. Rocz. Elbl. [T. 20]: 2006 s. $233-257$.

40. MISIUK Andrzej: Oficerskie szkolnictwo policyjne w Szczytnie (1954-2005). [W:] Powiat szczycieński. Przeszłość - współczesność. Praca zbior. pod red. Grzegorza Jasińskiego, Zbigniewa Kudrzyckiego i Andrzeja Misiuka. Szczytno 2006 s. 579-595.

41. MLECZKO Wojciech: Instytucje edukacyjne zmartwychwstańców. Zesz. Hist.-Teol. Nr 12: 2006 s. $167-188$, sum.

XIX-XX w.

42. MOŻDŻEŃ Stefan Ignacy: Historia wychowania. [Cz.] 2: 1795-1918. Wyd. 2. Sandomierz 2006 Wydaw. Diec. i Drukarnia ss. 397.

Toż. [Cz.] 3: 1918-1945. Wyd. 2 popr. Sandomierz 2006 ss. 275, il.

Wyd. 1. Kielce 2000.

[Cz. 1]. Wyd. 2. Kielce 2005.

43. MUZYKOLOGIA we Wrocławiu. Ludzie, historia, perspektywy. Red. Maciej Gołąb. Wrocław 2005 Wydaw. Uniw. Wrocławskiego ss. 167, nlb. 1, il., sum., Zsfg. ( Musicologica Wratislavensia; 1) (Acta Universitatis Wratislaviensis; no 2742).

Z treści: Gołąb M.: Wprowadzenie s. 5-9; Zduniak Maria: Muzyka i historia muzyki na Uniwersytecie Wrocławskim w XIX i w I połowie XX wieku s. 11-44; Mahling Christoph-Hellmut: Arnold Schmitz, muzykologia i wychowanie muzyczne na Królewskim Uniwersytecie im. Friedricha Wilhelma we Wrocławiu s. 45-51; Homma Martina: Muzykolodzy z Breslau po 1945 roku s. 53-70; Ugrewicz Adam: Hieronim Feicht i działalnošć Zakładu Muzykologii Uniwersytetu Wrocławskiego w latach 1945-1952 s. 71-90; Hrab Uljana: Adolf Chybiński i lwowska szkoła muzykologiczna s. 101-111; Jasinowski Jurij: Adolf Chybiński i jego ukraińscy uczniowie na Uniwersytecie Jana Kazimierza we Lwowie s. 113-118; Czekanowska Anna: Adolf Chybiński i jego polscy uczniowie na uniwersytetach we Lwowie i w Poznaniu s. 119-129; Muszkalska Bożena: Postać Marii Szczepańskiej w świetle materiałów archiwalnych s. 131-139; Nauka o muzyce na Uniwersytecie we Wrocławiu - krótkie kalendarium. Oprac. M. Gołąb s. 155-159. 
44. OŚWIATA - szkolnictwo - ZNP w gminie Aleksandrów Lódzki 1905-2005. Opracowania, materiały, źródła. Red. Tadeusz Jałmużna. Aleksandrów Lódzki 2005 ZO ZNP; Urząd Gminy ss. 320, il. ZNP Zarząd Oddz. w Aleksandrowie Łódzkim.

Z treści: Jałmużna T.: Wstęp s. 7-8; Rozdzial I. Z historii i współczesności edukacji przedszkolnej, szkolnej i opiekuńczo-wychowawczej w Gminie Aleksandrów Lódzki: Abramuk Krystyna: Wychowanie przedszkolne s. 13-24; Zawiślak Halina: Szkolnictwo podstawowe i gimnazjalne s. 25-26; Zawiślak H., Kwiatkowska Grażyna: Zespół Szkół Sportowych „Sportowa Trójka” s. 27-53; Majchrzak Halina: Miejski Zespół Szkół im. Jana Pawła II s. 54-65; Mistrzak Jolanta: Szkoła Podstawowa nr 4 im. Marii Skłodowskiej-Curie s. 66-79; Stańczyk Teresa, Zawišlak H.: Szkoła Podstawowa w Bełdowie s. 80-85; Patoleta Malgorzata, Kwiatkowska G.: Szkoła Podstawowa w Rąbieniu s. 86-90; Sobczak Bożena, Zawišlak H.: Szkoła Podstawowa w Rudzie Bugaj s. 91-94; Lichwała Stanisław: Historia i teraźniejszość szkolnictwa średniego s. 95-96; Lichwała S., Chejchman Zofia: Liceum Ogólnokształcące im. Mikołaja Kopernika w Aleksandrowie Ł. s. 97-126; Kowalska Danuta: Zespół Szkół Zawodowych im. Stanisława Staszica w Aleksandrowie Łódzkim s. 127-140; Ozimek Barbara, Pacholska Katarzyna, Jończyk Dorota, Wrzesiński Radosław: Szkolnictwo dla dzieci i młodzieży o specjalnych potrzebach edukacyjnych s. 141-146; Rafalska Ilona: Inne placówki oświatowo-wychowawcze s. 147-154; Szadkowska Teresa: Karty z historii zlikwidowanych szkół z naszej Gminy s. 157-164; Rozdział IV. Z dziejow i współczesności Związku Nauczycielstwa Polskiego: Raczyńska Stanisława: Z dziejów i współczesności Związku Nauczycielstwa Polskiego w Aleksandrowie Lódzkim s. 199-248; Szyszka Małgorzata: Związek Nauczycielstwa Polskiego w okresie transformacji ustrojowej w latach 1980-2005 s. 249-289; Lewandowski Ryszard: Sekcja Emerytów i Rencistów (informacje i refleksje) s. 290-294.

45. POLSKIE szkolnictwo artystyczne. Dzieje, teoria, praktyka. Materiały LIII Ogólnopolskiej Sesji Naukowej Stowarzyszenia Historyków Sztuki, Warszawa, 14-16 października 2004. Pod red. Marii Poprzęckiej. Warszawa 2005 Stow. Hist. Sztuki ss. 259, nlb. 2, il.

Z treści: Włodarczyk Wojciech: Studenci s. 33-48; Wybieralski Wojciech: Wzornictwo. Sztuka nie-sztuka? s. 57-61; Szpor Joanna: W kierunku myślenia monograficznego s. 63-67; Walentowicz Tadeusz, Lewicka-Morawska Anna: Po co uczyć teorii na uczelni artystycznej? s. 69-76; Nowak Barbara: Aleksander Ubelski (1649-1718) w Królewskiej Akademii Malarstwa i Rzeźby w Paryżu - edukacja i działalność dydaktyczna s. 79-95; Mączyński Ryszard: Edukacja plastyczna w warszawskich szkołach pijarów (1740-1833) s. 97-110; Giełdoń-Paszek Aleksandra: Tradycje nauczania malarstwa pejzażowego na polskich uczelniach artystycznych do roku 1939 s. 111-125; Stępień Halina: Dlaczego Monachium? s. 127-132; Styrna Natasza: Żydowscy studenci krakowskiej Akademii Sztuk Pięknych s. 133-144; Grzejszczak Lukasz: Szkolnictwo plastyczne w Lodzi w latach 1895-1939. Metody kształcenia i ich wplyw na rozwój miejscowego środowiska artystycznego s. 145-161; Mulczyński Jarosław: Rozwój szkolnictwa artystycznego w Poznaniu w 1 połowie XX wieku (do 1939 roku) s. 163-179; Kostuch Bożena: Pracownia ceramiczna, tak zwana szkoła Szafrana, w Państwowej Szkole Przemyshu Artystycznego w Krakowie s. 181-191; Liwak Katarzyna: Eksperymenty Antoniego Buszka z twórcami ludowymi s. 193-199; Sosnowska Joanna: Czego w Warszawskiej Szkole Sztuk Pięknych nauczyła się awangarda? s. 201-211; Chmielewska Agnieszka: Artysta-fachowiec jako wzorzec absolwenta warszawskiej ASP w okresie międzywojennym s. 213-222; Chrudzimska-Uhera Katarzyna: Działalność pedagogiczna rzeźbiarza Jana Szczepkowskiego s. 223-230; Antos Janusz: Kapiści i koloryści w wyższym szkolnictwie artystycznym w drugiej połowie lat czterdziestych XX w. s. 231-240; Baranowa Anna: Piotr Potworowski - uczeń i nauczyciel s. 241-250.

46. POZNAŃSKI Karol: Wybrane zagadnienia z historii wychowania. [Cz.] 2. Warszawa 2006 Wydaw. Akad. Pedagogiki Specjalnej im. Marii Grzegorzewskiej ss. 247.

Podręcznik akademicki; autor cz. 1: Markiewiczowa Hanna.

47. RADZANÓW i okolice - 615 lat. Zespół red. Agnieszka Ciechowicz [i in.]. Zwoleń-Radom 2006 Wydaw. Stow. Oświatowego Sycyna; Wydaw. Inst. Technologii Eksploatacji ss. 249, nlb. 5, tabl. 16, il. (Biblioteka Sycyńska; t. 27).

Oświata i wychowanie s. 137-212.

48. REDZIK Adam: Szkic z dziejów szkolnictwa wyższego we Lwowie. Niepod. i Pam. R. 13: $2006 \mathrm{nr} 3$ s. 93-109.

XVIII-XX w. 
49. ROWIŃSKI Rafał, Dąbrowski Andrzej: Wychowanie dzieci i młodzieży do turystyki i rekreacji w działalności Polskiego Towarzystwa Turystyczno-Krajoznawczego. Rocz. Nauk. AWF. T. 44: 2005/2006 [dr.:] 2006 s. 85-107, abstr.

50. SAPIA-DREWNIAK Eleonora: $Z$ tradycji działalności kulturalno-oświatowej na Śląsku Opolskim. Opole 2006 Wydaw. Uniw. Opolskiego ss. 152.

XIX-XX w.

51. SERAFIN Anna: Dzieje szkolnictwa na terenie gminy Uchanie (1820-2006). [W:] Dzieje Uchań 1484-2006. Pod red. Kazimierza Spaleńca. Uchanie-Lublin 2006 s. 137-166.

52. SMOLALSKI Antoni: Z dziejów salariatu nauczycielskiego w Polsce. Prz. Hist.-Ośw. R. 49: $2006 \mathrm{nr} 3 / 4$ s. 5-13.

XIII-XX w.

53. STOSUNKI polsko-ukraińskie w szkolnej edukacji historycznej od XIX do XXI wieku. Materiały konferencji naukowej, 21-22 października 2004 r., Cedzyna k. Kielc. Pod red. Hanny Wójcik-Lagan. Kielce 2005 Kieleckie Tow. Nauk.; Akad. Świętokrzyska im. Jana Kochanowskiego ss. 361, nlb. 3, il., sum. Kieleckie Tow. Nauk.; Inst. Hist. Akad. Świętokrzyskiej.

Z treści: Wójcik-Łagan H.: Wstęp s. 9-10; Cesarz-Maternicka Elżbieta, Maternicki Jerzy: Sąsiedztwo państw i narodów w edukacji historycznej młodzieży s. 25-32; Massalski Adam: Nauczyciele Ukraińcy w rządowych szkołach średnich Królestwa Polskiego w latach 1833-1862 s. 45-71; Puszka Alicja: Nauczyciele historii i geografii pochodzenia ukraińskiego w szkolnictwie średnim Galicji w okresie autonomii s. 73-86; Kula Ewa: Nauczyciele i uczniowie Szkoły Rabinów w Żytomierzu w latach 1847-1873 s. 87-102; Błachowska Katarzyna: Dzieje Rusi Małej w dziewiętnastowiecznej historiografii rosyjskiej s. 103-114; Stinia Maria: Sprawy szkolnictwa ukraińskiego na łamach „Muzeum” w latach 1885-1914; Górczyński Wit, Stępniak Andrzej: Stosunki polsko-ukraińskie w rosyjskich podręcznikach dla szkół Królestwa Polskiego (okres międzypowstaniowy) s. 125-134; Pisulińska Joanna: Żydzi, Ukraińcy, Polacy - wzajemne relacje w podręcznikach dziejów Polski XIX wieku (do 1914 roku) s. 135-143; Malczewska-Pawelec Dorota: Obraz Ukrainy i stosunków polsko-ukraińskich w podręczniku Anatola Lewickiego „Zarys historii Polski i krajów ruskich z nią połączonych" s. 145-161; Sanojca Karol: Utrakwizacja szkolnictwa ukraińskiego na Kresach Wschodnich II Rzeczypospolitej - interpretacje i oceny s. 165-178; Halczak Bohdan: Wpływ „ustawy szkolnej Grabskiego" na stosunki polsko-ukraińskie w latach 1924-1939 s. 179-188; Okła Grażyna: Ukraina i Ukraińcy w międzywojennych podręcznikach historii s. 189-194; Kubis Barbara: Stosunki polsko-ukraińskie w latach II wojny światowej w świetle wspomnień s. 197-212; Jakubowska Barbara: Najnowsza historia Ukrainy - kilka obowiązkowych lektur s. 213-222; Konopka Hanna: Problemy ukraińskie na Białostocczyźnie s. 223-233; Centkowski Jerzy: Obraz dziejów Ukrainy i stosunków polsko-ukraińskich w powojennych podręcznikach dla szkół srednich s. 235-242; Glimos-Nagórska Anna: Obraz stosunków polsko-ukraińskich w XX wieku w podręcznikach historii do gimnazjum. Próba porównania z przekazem zawartym w opracowaniach szkolnych $\mathrm{z}$ lat 1945-1996; Młynarczyk Anita: Obraz stosunków polsko-ukraińskich w programach nauczania i podręcznikach do historii przeznaczonych dla liceów pedagogicznych w latach 1944-1970; Jóźwiak Iwona: Szkolnictwo ukraińskie w pierwszych latach po II wojnie światowej na terenie województwa olsztyńskiego s. 275-294; Fic Maciej: Obraz Ukrainy we współczesnych podręcznikach ponadgimnazjalnych - wyraz uprzedzenia czy szansa na integrację? s. 295-305; Wójcik-Lagan H.: Kozacy w tradycyjnych i nowych narracjach podręcznikowych. Propozycje dla autorów s. 307-319; Konieczka-Śliwińska Danuta: Bohaterowie dziejów Ukrainy w polskich podręcznikach historii dla szkoły podstawowej i gimnazjum z lat 1989-2004 s. 321-336; Bednarzak-Libera Mirosława: Materiały dydaktyczne pomocne w nauczaniu o stosunkach polsko-ukraińskich s. 337-347.

54. STUDIA z dziejów Bełżyc. Belżyce-Lublin 2006 Tow. Region. Bełżyc; Polihymnia ss. 349, il. Zarys dziejów oświaty w Bełżycach. Oprac. Elżbieta Kaszlikowska [i in.] s. 235-291.

55. SZKARADNIK Lidia: Szkolnictwo. [W:] Ustroń 1305-2005. Praca zbiorowa. T. 1: 1305-1945. Red. nauk. Idzi Panic. Ustroń 2005 s. 395-416. 
56. ŚLIWA Ewa: Szkice z dziejów oświaty w Boguchwale od połowy XV wieku do 1944 roku. [W:] [Pięćdziesiąt] 50 lat Gminnej Biblioteki Publicznej 1956-2005. Oprac. red. E. Śliwa. Boguchwała 2006 s. 51-70.

57. TĘŻYCKI Mieczysław: Zarys szkolnictwa w Grudziądzu w latach 1920-1970. Toruń 2006 Adam Marszałek ss. 128, il.

58. TORZEWSKI Marian: Oświata i kultura. [W:] Września historia miasta. Praca zbior. pod red. M. Torzewskiego. Września 2006 s. 348-380.

59. TOWARZYSTWO Czytelni Ludowych we Wrześni. Przeszłość i teraźniejszość. Red. Bolesław Święciochowski. Września 2006 Tow. Czytelni Ludowych; Wrzesińskie Tow. Kult. ss. 108, il. (Biblioteczka WTK; 8).

Z treści: Święciochowski B.: Wstęp s. 5-6; Cz. 1: Kostrzewski Leopold: Z dziejów TCL we Wrześni (1880-1939) s. 7-61; Cz. 2: Towarzystwo Czytelni Ludowych Koło im. bł. Edmunda Bojanowskiego we Wrześni (1995-2005) s. 65-107.

60. TRADYCJE akademickie Elbląga - dawniej i dziś. Materiały pokonferencyjne. Pod red. Józefa Borzyszkowskiego. Elbląg 2006 Elbląska Uczelnia Humanist.-Ekonom. ss. 134, nlb. 1, il.

Materiały sesji popularnonaukowej na temat „Tradycje akademickie Elbląga - dawniej i dziš". Elbląg, 17 XII 2004 r.

Z treści: Borzyszkowski J.: Słowo wstępne s. 9-12; Pawlak Marian: Elbląskie Gimnazjum Akademickie jego dzieje i wychowankowie w historii miasta i regionu s. 17-31; Walczyk Zbigniew: Dotychczasowe osiągnięcia i perspektywy rozwoju Państwowej Wyższej Szkoły Zawodowej w Elblągu - spadkobierczyni Politechniki Gdańskiej i dwóch kolegiów nauczycielskich s. 33-68; Dubiella Zdzisław: Elbląska Uczelnia Humanistyczno-Ekonomiczna - jej wczoraj, dziś i jutro a perspektywy rozwoju Elblagga i regionu s. 69-83; Ewertowski Stefan: Studia teologiczne na terenie diecezji elbląskiej s. 85-103; Hochleitner Janusz: Od Uniwersytetu Gdańskiego do Wydziału Zamiejscowego w Elblągu Szkoły Wyższej im. Bogdana Jańskiego s. 105-122.

61. WALASEK Stefania: Szkolnictwo powszechne na ziemiach północno-wschodnich II Rzeczypospolitej (1915-1939). Kraków 2006 Impuls ss. 324, il., sum., rez.

62. WŚRÓD „swoich” i „obcych”. Rola edukacji w społeczeństwach wielokulturowych Europy Środkowej (XVIII-XX wiek). Pod red. nauk. Stefanii Walasek. Kraków 2006 Oficyna Wydawnicza „Impuls” ss. 374.

Z treści: Walasek S.: Wstęp s. 9-15; Szybiak Irena: Szkoła a narodowość w świetle oświeceniowych idei i reform edukacyjnych (kilka refleksji) s. 39-48; Skowroński Michał: Szkoła Rabinów w Warszawie (1826-1863). Jaki był cel jej istnienia? s. 55-58; Wołczuk Janina: Wiedza o Rosji czy rusyfikacja? (uwagi o postrzeganiu Rosji przez Polaków edukujących się w epoce mikolajowsko-paskiewiczowskiej) s. 59-72; Piwowarczyk Mirosław: Aktywność społeczna mniejszości niemieckiej w powiecie gostyńskim w II Rzeczypospolitej s. 107-117; Walasek S.: Edukacyjne aspiracje wielonarodowościowej społeczności na przykładzie ziem północno-wschodnich II Rzeczypospolitej s. 119-131; Wróblewska Urszula: Wileńskie Koło Młodzieży Tatarskiej jako główny inicjator i koordynator działalności społecznej młodzieży tatarskiej w okresie międzywojennym s. 133-144; Meducka Marta: Dom, szkoła, środowisko rówieśnicze w budowaniu tożsamości narodowej młodzieży żydowskiej przed 1939 rokiem (w świetle pamiętników) s. 145-158; Luczyńska Barbara: Towarzystwo Nauczycieli Szkół Wyższych organizacją integrującą zróżnicowane narodowościowo środowisko nauczycieli Galicji s. 161-175; Pękowska Marzena: Wielokulturowa społeczność uczniów lwowskich szkół dla głuchoniemych i niewidomych (1830-1939) s. 177-185; Puchowska Małgorzata: „Polskie Eton”. Edukacja kulturalna elit w konwikcie chyrowskim (1886-1939) s. 187-201; Stinia Maria: Dorobek wielokulturowego środowiska gimnazjalnego Krakowa w okresie autonomii galicyjskiej - nauczanie i nauczyciele religii mojżeszowej s. 203-212; Kula Ewa: Nauczyciele religii mojżeszowej w rządowych męskich szkołach średnich Królestwa Polskiego w drugiej połowie XIX wieku s. 213-229; Szarkowska Agnieszka: Prywatne Hebrajskie Koedukacyjne Seminarium Nauczycielskie w Grodnie w okresie II Rzeczypospolitej jako przykład szkoły dla mniejszości narodowych s. 231-252; Sanojca Karol: Katecheci - księża greckokatoliccy wobec państwa polskiego w latach 
1918-1939 s. 253-263; Wolter Edyta: Symbolika europejska i jej dziedzictwo na wybranych przykładach edukacji ekologicznej w II Rzeczypospolitej s. 265-273; Sapia-Drewniak Eleonora: Tradycje szkolnictwa mniejszościowego na Śląsku opolskim (1918-2002) s. 275-290; Albański Leszek: Działalność opiekuńczo-wychowawcza Zgromadzenia Sióstr Służebniczek Najświętszej Maryi Panny Niepokalanie Poczętej Śląskiej w latach 1850-2000 s. 305-313; Mikłaszewicz Irena: Sowiecka polityka oświatowa na Wileńszczyźnie w latach 1944-1953 s. 337-347; Haratyk Anna: Zarys historii szkolnictwa na Huculszczyźnie w XX wieku s. $349-362$.

63. ZIEMIA Lipska. T. 1. Pod red. Czesława Barańskiego. Lipsko-Warszawa 2006 Nobles-net ss. 332 , il.

Z treści: Choraś Maria: Alfabetyzacja w I połowie XIX wieku s. 105-106; Barański Czesław: Oświata s. $179-206$.

\section{Okres do 1795 roku}

64. BOGDAN Danuta: Wpływ Uniwersytetu Królewieckiego na ksztaltowanie się elity kulturalnej Mazur w XVI-XVIII wieku. Masovia. T. 9: 2006 s. 37-52.

65. BOKOTA Piotr: Wykształcenie mieszczan włocławskich od XVI do XVIII wieku. Cz. 1: XVI wiek. Zap. Kuj.-Dobrz. T. 20: 2005 s. 9-17.

66. BUKAŁA Marcin: Znaczenie problematyki logicznej w średniowiecznym szkolnictwie dominikańskim na przykładzie szkoły wrocławskiej. [W:] Człowiek - obraz - tekst. Studia z historii średniowiecznej i nowożytnej. Pod red. Marka L. Wójcika. Dzierżoniów 2005 s. 65-75.

67. BURDA Bogumiła: Porządki szkolne, Ordynacje, Plany lekcji i Regulaminy protestanckiego szkolnictwa średniego na Dolnym Śląsku w okresie wczesnonowożytnym. [W:] Polacy, Niemcy, Pogranicze. Studia historyczne. Red. nauk. Grażyna Wyder, Tomasz Nodzyński. Zielona Góra 2006 s. 111-120.

68. CHACHAJ Marian: Orszak magnata odbywającego podróż edukacyjną (wiek XVI-XVIII). [W:] Patron i dwór. Magnateria Rzeczypospolitej w XVI-XVIII wieku. Pod red. Ewy Dubas-Urwanowicz i Jerzego Urwanowicza. Warszawa 2006 s. 165-178.

69. CHACHAJ M.: Wykształcenie Tarłów od połowy XV do połowy XVII wieku. [W:] Tarłowie. Rola i znaczenie rodziny w dziejach ogólnonarodowych i lokalnych XVI-XIX wieku. VI Janowieckie Spotkania Historyczne. Sesja naukowa odbyła się dnia 24 czerwca 2006 roku na zamku w Janowcu (Dom Północny). Red. Henryk Gmiterek, Andrzej Szymanek. Janowiec nad Wisłą 2006 s. 52-71.

70. CWER Andrzej: Wychowanie obronne młodzieży polskiej w XVIII stuleciu. Prz. Hist.-Ośw. R. 49: 2006 nr 1/2 s. 13-62.

71. GRAFF Tomasz: Kariera, pochodzenia społeczne i wykształcenie episkopatu metropolii lwowskiej (do 1412 roku halickiej) w pierwszej połowie XV wieku. Zesz. Nauk. UJ. [Nr] 1284: Prace Hist. Z. 133: 2006 s. 31-41, sum.

72. JUREK Tomasz: Krakowski dyplom promocji magisterskiej z 1512 roku. Rocz. Krak. T. 72: 2006 s. 69-85, sum.

Zawiera też dokument. 
73. KACZOROWSKI Robert: Edukacja muzyczna w szkołach jezuickich na Warmii. Studia Elbl. T. 5: 2003 s. $105-119$, Zsfg.

74. KADRYŚ Piotr: Problematyka nauczania elementarnego w szkolnictwie polskim okresu średniowiecza. Almanach Hist. T. 8: 2006 s. 21-32.

75. KAMLER Anna: Od szkoły do senatu. Wykształcenie senatorów w Koronie w latach 1501-1586. Studia. Warszawa 2006 Oficyna Wydawnicza Aspra-Jr ss. 365, nlb. 1. Inst. Informacji Nauk. i Studiów Bibliol. Uniw. Warszawskiego.

76. KARAFFA Jan: Schola Ludus J. A. Komenského a současné pojetỉ dramatické výchovy. [W:] Wspólnota dziedzictwa kulturowego. Red. Bronisława Dymara [i in.]. Kraków 2004 s. $137-148$.

77. [KAVALČ́UK Natallâ] Kavalchuk Natallia: Opereta „Apollo prawodawca” - intermedia w przedstawieniu szkolnym. Muzyka. R. 51: $2006 \mathrm{nr} 4$ s. 27-51, sum.

Przygotowana przez Michała Ciecierskiego i wystawiona 3 XII 1789 r., artykuł dot. przedstawień w XVIII w. w Polsce i na Litwie.

78. KORZENIOWSKA Wiesława: Johann Ignaz von Felbiger i jego program reorganizacji szkolnictwa elementarnego - na Śląsku pruskim i w krajach austriackich [1765]. [W:] Wspólnota dziedzictwa kulturowego. Red. Bronisława Dymara [i in.]. Kraków 2004 s. 187-195.

79. KUPIS Bogdan: Niedoceniony podręcznik retoryki Stanisława Papczyńskiego (1631-1701). Lublin-Warszawa 2006 Promic. Oddz. Wydaw. Ks. Marianów MIC ss. 367, nlb. 1. (Studia Marianorum; 10).

80. MARKIEWICZ Anna: Podróż edukacyjna Adama Mikołaja Sieniawskiego na zachód Europy (1684-1686). Zesz. Nauk. UJ. [Nr] 1284: Prace Hist. Z. 133: 2006 s. 43-54, sum.

81. MĄCZYŃSKI Ryszard: Architekt Komisji Edukacji Narodowej. Nadzór nad budynkami szkół w latach 1777-1793. Analecta. R. 15: 2006 z. 1/2 s. 7-88, sum.

82. OŻÓG Krzysztof: Elity intelektualne w Polsce średniowiecznej. Stan i perspektywy badań. [W:] Genealogia. Stan i perspektywy badań nad społeczeństwem Polski średniowiecznej na tle porównawczym. Pod red. Jana Pakulskiego, Jana Wroniszewskiego. Toruń 2003 s. 181-210.

83. PAWLAK Marian: Szkoły parafialne na Kujawach w epoce staropolskiej. Bydgoszcz 2006 Wydaw. Uniw. Kazimierza Wielkiego ss. 166, tabl. 1, il., Zsfg.

XVI-XVIII w.

Rec.: Mietz Andrzej, Zapiski Kujawsko-Dobrzyńskie. T. 20: 2005 s. 204-207; Rosa Agnieszka, Ziemia Kuj. T. 19: 2006 s. 159-162.

84. RATAJCZAK Krzysztof: Edukacja kobiet w kręgu dynastii piastowskiej w średniowieczu. Poznań 2005 Wydaw. Poznańskie ss. 218, nlb. 2. (Poznańskie Studia Historyczne).

85. SZARSZEWSKI Adam: Sprawy szpitali i sierocińców w aktach prawnych Rady Miasta Gdańska XVI-XVIII wieku. Toruń 2006 Wydaw. Nauk. Grado ss. 289. (Hospitalia Gedanensia. Fontes; vol. 4).

86. TYGIELSKI Wojciech: Na cóź te koszta i trudy? W jakim celu w XVII wieku wysyłano młodzież szlachecką na zagraniczne studia?. Odrodzenie $i$ Reformacja $w$ Polsce. T. 50: 2006 s. $141-156$, sum. 
87. WESOLOWSKA Sylwia: Wpływ ideologii reformacyjnej na nauczanie w szkołach pomorskich. [W:] Życie dawnych Pomorzan. [Cz. 3:] Materiały z konferencji, Bytów, 14-15 października 2004. Pod red. Wojciecha Łysiaka. Poznań 2006 s. 39-48.

88. ZONTA Claudia A.: Schlesische Studenten an italienischen Universitäten. Eine prosopographische Studie zur frühneuzeitlichen Bildungsgeschichte. Köln [i in.] 2004 Böhlau ss. X, 539, il., streszcz. (Neue Forschungen zur Schlesischen Geschichte; 10).

\section{Okres $1795-1918$}

89. ANKIETA na temat „higieny domowej”, „wychowania moralnego" $\mathrm{i}$ „uświadomienia narodowego" uczniów szkół radomskich z 1915/16 roku. [Wyd.] Marek Przeniosło. Między Wista a Pilica. T. 7: 2006 s. $171-173$.

Ze zbiorów Archiwum Państ. w Radomiu.

90. BARAŃSKI Józef: Nauczyciele szkół elementarnych na Mazowszu północnym w latach 1815-1862. Status materialny i rola w społeczności lokalnej. Prz. Hist.-Ośw. R. 49: $2006 \mathrm{nr}$ 3/4 s. $157-174$.

91. BARON Roman: Nad Olzą i Ostrawicą. Działalność społeczno-wychowawcza i oświatowa Towarzystwa Szkoły Ludowej w Zagłębiu Ostrawsko-Karwińskim (1894-1919). Opole 2006 Wydaw. Uniw. Opolskiego ss. 150, shrnut-, sum., Zsfg. Uniw. Opolski.

Rec.: Kosmanowa Bogumiła, Prz. Zach. R. 62: 2006 nr 3 s. 259-261; Pałys Piotr, Śl. Kw. Hist. Sobótka. R. $61: 2006$ ir 3

92. BEDNARZAK-LIBERA Mirosława: Karta $\mathrm{z}$ dziejów walki $\mathrm{z}$ analfabetyzmem Polaków rekrutowanych do sił zbrojnych Habsburgów stacjonujących w autonomicznej Galicji. [W:] Dzieje wojsko - społeczeństwo. Studia ofiarowane prof. dr. hab. Edwardowi Pawłowskiemu z okazji sześćdziesiątej piątej rocznicy urodzin. Red. nauk. Henryk Hermann, Stanisław Jaczyński, Hubert Królikowski. Siedlce 2006 s. 49-64.

93. BEDNARZAK-LIBERA M.: Rola książki w działalności Towarzystwa Szkoły Ludowej (1891-1918). Szkic do dziejów książki w Krakowie. Annales APC. Folia 39: Studia ad Bibliothecarum Scientiam Pertinentia. [T.] 4: 2006 s. 177-197, abstr.

94. BEDNARZAK-LIBERA M.: Wkład Towarzystwa Pedagogicznego i Towarzystwa Szkoły Ludowej w rozwój polskiego szkolnictwa średniego w Galicji w latach 1867-1918. [W:] Wojsko i kultura w dziejach Polski i Europy. Księga jubileuszowa profesora Piotra Matusaka w 65. rocznicę urodzin. Praca zbiorowa. Pod red. Rafała Dmowskiego [i in.]. Siedlce-Warszawa 2006 s. 196-211.

95. BOGDANOWSKI Wincenty: Moje wspomnienia (czasy gimnazjalne). Do dr. podał Sylwester Dziki. Malopolska. [T.] 7: 2005 s. 255-263.

Wspomnienia z 1. 1906-1913 z Wadowic; autor żył w 1. 1894-1982.

96. BUDZIŃSKI Krzysztof: Udział Czesława Jarnuszkiewicza [1888-1988] w strajku szkolnym i rewolucji we Włocławku w latach 1905-1906. Ziemia Dobrz. R. 10: 2006 s. 35-47.

97. CABAJ Jarosław: Kongresy pedagogów polskich $(1894,1909)$ - forum wymiany poglądów w skali międzyzaborowej. [W:] Wojsko i kultura w dziejach Polski i Europy. Księga jubileuszowa profesora Piotra Matusaka w 65. rocznicę urodzin. Praca zbiorowa. Pod red. Rafała Dmowskiego [i in.]. Siedlce-Warszawa 2006 s. 178-195. 
98. CHOJECKI Dariusz: Monety rzymskie w zbiorach XIX-wiecznych gimnazjów Górnego Śląska. Wiad. Num. R. 50: 2006 z. 2 s. 159-171, sum.

99. CZAPSKA Małgorzata: Wykształcenie i kwalifikacje nauczycieli szkół średnich rządowych męskich w guberni kieleckiej w latach 1873-1905. [W:] Z tradycji i dorobku inteligencji kieleckiej w XIX i XX wieku. Pod red. Marty Meduckiej. Kielce 2005 s. 191-233.

100. DORMUS Katarzyna: Problematyka wychowawczo-oświatowa w prasie kobiecej zaboru austriackiego w latach 1826-1918. Warszawa 2006 Wydawnictwa IHN PAN; Wydaw. Retro-Art ss. 453, nlb. 3. PAN. Inst. Historii Nauki. Zakł. Dziejów Oświaty. ( Monografie z Dziejów Oświaty; t. 40).

101. FRĄCKIEWICZ Joanna: Edukacja narodowa najmłodszego syna Adama Mickiewicza. Prz. Hist.-Ośw. R. 49: $2006 \mathrm{nr}$ 3/4 s. 41-62.

Józef Mickiewicz (1850-1938).

102. FUDALI Robert: Rola społeczna nauczycieli w polskiej myśli pedeutologicznej na przełomie XIX i XX wieku. Prz. Hist.-Ośw. R. 49: 2006 nr 3/4 s. 15-25.

103. GALEK Czesław: Myśl pedagogiczna Bolesława Prusa [1847-1912] na tle pozytywizmu polskiego. Rocz. Teol. T. 53: 2006 z. 4 s. $185-192$.

104. GALEK Cz.: Poglądy Bolesława Prusa na wychowanie dzieci i młodzieży. Prz. Hist.-Ośw. R. 49: $2006 \mathrm{nr} 3 / 4$ s. $75-93$.

105. HAPTAŚ Krzysztof: Materiały źródłowe do dziejów budowy Bursy gimnazjalnej w Mielcu (lata 1909 i 1911-1912). Rocz. Miel. T. 7/8: 2004/2005 [dr.:] 2006 s. 277-286.

W aneksie: Protokoły posiedzeń Rady Gminnej w Mielcu z 1. 1909-1912, obecnie w zbiorach Archiwum Państwowego w Rzeszowie oraz notatki Jana Haładaja z 1. 1911-1912, obecnie w Muzeum Regionalnym w Mielcu.

106. HUCZ-CIĘZKA Agnieszka: Szkolnictwo i oświata rządowa w dobrach włodawskich Zamoyskich w latach 1837-1917. Lub. Rocz. Pedag. T. 25: 2005 s. 173-191.

107. JASIŃSKI Grzegorz: Dom sierot w Barczewie - przykład ewangelickiego zakładu opieki na terenie diaspory w XIX wieku. [W:] Ad fontes. Studia ofiarowane księdzu profesorowi Alojzemu Szorcowi w siedemdziesięciolecie urodzin. Pod red. Zoi Jaroszewicz-Pieresławcew i Ireny Makarczyk. Olsztyn 2006 s. 115-127.

108. JASIŃSKI G.: Szkolnictwo w powiecie szczycieńskim w XIX wieku. [W:] Powiat szczycieński. Przeszłość - współczesność. Praca zbior. pod red. Grzegorza Jasińskiego, Zbigniewa Kudrzyckiego i Andrzeja Misiuka. Szczytno 2006 s. 277-305.

109. KAŁAMACKA Ewa: Zdrowotno-higieniczne aspekty wychowania fizycznego w poglądach i działalności polskich lekarzy do 1914 r. Kraków 2003 Akad. Wychowania Fizycznego im. Bronisława Czecha ss. 324, sum. Akad. Wychowania Fizycznego im. Bronisława Czecha. (Studia i Monografie; nr 20).

110. KAŁUŹNIAK Dorota: Geneza opieki nad dzieckiem i higiena wychowawcza na przełomie XIX i XX wieku. Piotrk. Studia Pedag. T. 12: 2006 s. 67-73.

111. KOBENDZA Ryszard Lucjan: Polskie szkolne organizacje wioślarskie na Pomorzu i w Wielkopolsce w latach 1894-1918. [W:] Z dziejów wioślarstwa w Polsce. Materiały z sesji 
popularnonaukowej odbytej 15 października 2004 roku w Poznaniu. Pod red. R. L. Kobendzy i Leonarda Nowaka. Gorzów Wlkp.-Warszawa 2005 s. 17-25.

112. KOSTRZEWSKA Ewelina: Edukacja domowa ziemianek w Królestwie Polskim na początku XX w. Propozycja w świetle „Świata Kobiecego”. [W:] Studia z historii społeczno-gospodarczej XIX i XX wieku. T. 4. Pod red. Wiesława Pusia. Łódź 2006 s. 142-156.

113. KOZERA Andrzej: Źródła myśli oświatowej ruchu ludowego do 1918 roku. Rocz. Muz. Nar. $w$ Kielcach. T. 22: 2006 s. 213-223, sum.

114. KULA Ewa: Dorpatczycy w rządowych szkołach średnich Królestwa Polskiego (1862-1873). [W:] Ważna obecność. Przedstawiciele państw i narodów europejskich wśród mieszkańców międzyrzecza Bugu i Pilicy w XVII-XIX wieku. Materiały sesji naukowej, Radom, 30 listopada 2006 r. Pod red. Artura Góraka i Krzysztofa Latawca. Radzyń Podlaski-Radom 2006 s. 239-251.

115. KULA E.: Naukowa, literacka i artystyczna twórczość nauczycieli rządowych męskich szkół średnich Królestwa Polskiego w latach 1833-1862. Kielce 2006 Wydaw. Akad. Świętokrzyskiej im. Jana Kochanowskiego ss. 243, nlb. 5, il.

116. KULKA Bronisława: Edukacja polonistyczna w szkole średniej w latach 1870-1918. Wybrane uwarunkowania. Cz. 1. Częstochowa 2005 Wydaw. Akad. im. Jana Długosza ss. 600, tabl. 3, il. Akad. im. Jana Długosza w Częstochowie.

117. KULKA B.: Lektura dzieł Adama Mickiewicza w działalności samokształceniowej stowarzyszenia „Jedność” w Cieszynie. Prz. Hist.-Ośw. R. 49: 2006 nr 3/4 s. 63-73.

Lata 1886-1914.

118. LESZCZAK Teodor: Podręcznik Edwarda Mildego jako źródło kształcenia nauczycieli na Uniwersytecie Lwowskim w pierwszej połowie wieku XIX. Lub. Rocz. Pedag. T. 25: 2005 s. 209-214.

119. MAASS Helga: Über die Lehrergehälter an den evangelischen Privatschulen in Galizien um 1912. Zeitweiser der Galiziendeutschen. Bd. 43: 2005 s. 243-258.

121. MARKIEWICZOWA Hanna: Społeczny ruch oświatowy w Królestwie Polskim u schyłku XIX i na początku XX wieku. Prz. Hist.-Ośw. R. 49: 2006 nr 1/2 s. 63-72.

Do 1907 r.

122. MARKOWICZ Przemysław: Wychowanie fizyczne w tarnowskich męskich szkołach średnich w latach 1867-1918. [W:] Z najnowszej historii kultury fizycznej w Polsce. T. 7: Prace naukowe Letniej Szkoły Historyków Kultury Fizycznej. Pod red. Leonarda Nowaka. Gorzów Wielkopolski 2006 s. 43-54.

123. MEISSNER Andrzej: Edukacja dzieci i młodzieży w powiecie kolbuszowskim w okresie autonomicznym 1867-1918. [W:] Miasteczko i okolica - od średniowiecza do współczesności. Red. Jadwiga Hoff; współpr. red. Jacek Bardan, Inga Kunysz. Kolbuszowa 2006 s. 219-235.

124. MEISSNER A.: Idee pedagogiczne Oświecenia w badaniach lwowskich historyków wychowania w latach 1867-1918. [W:] Bagatokul'turne ěstorične seredovise L'vova v XIX-XX stilëttâh. Wielokulturowe środowisko historyczne Lwowa. Za red. Leoněda Zaškěl'âka i Jerzego Maternickiego. T. 4. L'věv-Žešuv 2006 s. 304-315. 
125. MEUS Konrad: „Fundacja stypendyjna imienia Seweryna Arzta, dyrektora gimnazjum w Wadowicach" - czyli zapomoga dla ubogich uczniów gimnazjum wadowickiego w latach 1909-1918. Wadoviana. Nr 10: 2006 s. 43-48.

126. NOBIS Jadwiga, Nobis Kazimierz: Szkolnictwo ludowe w latach 1915-1918 w świetle materiałów archiwalnych zespołów akt C i K Komend Powiatowych przechowywanych w zasobie Archiwum Państwowego w Kielcach. Arch. Pol. R. 11: 2006 nr 1 s. 53-64, sum.

127. NOWAK Mariusz: Zaangażowanie mieszkańców powiatu pińczowskiego w działalność lokalnych organizacji społecznych i oświatowych na przełomie XIX i XX wieku. Malopolska. [T.] 7: 2005 s. 19-44.

128. POLSKOJEZYYCZNE podręczniki dla klasy i szkoły elementarnej w Królestwie Polskim drukowane grażdanką. Wydania warszawskie ze zbiorów Biblioteki Jagiellońskiej w Krakowie. Rozprawa filol.-hist. i ed. Maria Strycharska-Brzezina. Kraków 2006 PAU ss. 612, il. PAU. (Prace Komisji Wschodnioeuropejskiej; t. 10).

W aneksie: Fototypiczna edycja polskojęzycznych podręczników grażdańskich dla klasy i szkoły elementarnej w Królestwie Polskim: Elementarz dla dzieci wiejskich s. 85-204; Chestomatija wiejska czyli zbiór wypisów z różnych polskich autorów s. 207-297; Grammatyka języka polskiego s. 300-412; Krótki zbiór historii Starego i Nowego Testamentu s. 415-542; Począłkowa nauka arytmetyki dla użytku szkółek elementarnych wiejskich i miejskich s. 545-612.

129. POTOCZNY Jerzy: Nauczyciel dorosłych i popularyzator wiedzy $w$ galicyjskiej teorii i praktyce andragogicznej przełomu XIX i XX stulecia. Zesz. Nauk. Uniw. Rzesz. Nr 24: Ser. Pedagog.: Pedagogika i Psychologia. [Z.] 2: 2004 s. 175-195, streszcz., sum.

130. POTOCZNY J.: Wkład Proswity w rozwój ruchu społeczno-kulturalnego i oświatowego w Galicji doby autonomicznej. Zesz. Nauk. Uniw. Rzesz. Nr 36: Ser. Pedagog.: Pedagogika i Psychologia. [Z.] 3: 2006 s. 64-78, sum.

Ukraińskie towarzystwo kulturalno-oświatowe, powstałe 8 XII 1868 r.

131. PUDŁOCKI Tomasz: Recepcja Mickiewicza w I Gimnazjum w Przemyślu w czasach galicyjskich. Rocz. Przem. T. 42: 2006 z. 3 s. 57-64.

132. SALA Marta: Młodzież gimnazjów kieleckich podczas strajku szkolnego 1905 roku. [W:] Elementy społeczno-narodowe w rewolucji 1905 r. Pod red. Janusza R. Budzińskiego i Tomasza Matuszaka. Piotrków Trybunalski 2006 s. 41-52.

133. SCHILLER Joanna: Tadeusza Zielińskiego koncepcja reformy rosyjskich uniwersytetów. Kw. Hist. Nauki i Techn. R. 51: 2006 nr 3/4 s. 57-89, sum.

Lata 1905-1907.

134. SCHREIBER-KURPIES Dorota: Domy Dobrego Pasterza we Wrocławiu i Świętej Katarzynie w świetle sprawozdań z lat 1859-1913. Opieka nad „trudną” młodzieżą żeńską na Śląsku. [W:] Zakony żeńskie na Śląsku w XIX i XX wieku. Red. nauk. Wanda Musialik. Opole 2006 s. 45-60.

135. SIWICKA Dorota: Mickiewicz na uniwersytecie. [W:] Romantycy i Europa. Marzenia, doświadczenia, propozycje. Pod red. Marty Piwińskiej. Warszawa 2006 s. 106-113.

136. SŁAWIŃSKI Piotr: Rosjanie w szkołach Sandomierza (1866-1915). [W:] Ważna obecność. Przedstawiciele państw i narodów europejskich wśród mieszkańców międzyrzecza Bugu i Pi- 
licy w XVII-XIX wieku. Materiały sesji naukowej, Radom, 30 listopada 2006 r. Pod red. Artura Góraka i Krzysztofa Latawca. Radzyń Podlaski-Radom 2006 s. 253-276.

137. STELMACH Maria: Założenia statutowe Lwowskiego Towarzystwa Miejskich Ochronek Chrześcijańskich Małych Dzieci. Zesz. Nauk. Uniw. Rzesz. Nr 36: Ser. Pedagog.: Pedagogika i Psychologia. [Z.] 3: 2006 s. 79-87, sum.

Statut z 17 V 1897 r., zatwierdzony przez Radę Miejską 10 III 1898 r.

138. STINIA Maria: Kałamarz i szabla. Problematyka powstań narodowych w edukacyjnej rzeczywistości gimnazjów galicyjskich czasów autonomii. [W:] Polskie powstania narodowe - w 85. rocznicę wybuchu III powstania śląskiego. XVIII Tarnogórska Sesja Naukowa. Pod red. Marka Wrońskiego. Tarnowskie Góry 2006 s. 30-37.

139. SZCZEPAŃSKI Jacek: Prawosławna szkoła parafialna w twierdzy Zegrze 1912-1914. Rocz. Legion. T. 2: 2006 s. 209-214.

140. ŚMIECHOWSKA Elżbieta: Koncepcja wychowania człowieka w pismach pedagogicznych Adolfa Dygasińskiego. Maz. Studia Hum. R. 11: 2005 nr 1/2 s. 229-238.

141. TARASIUK Dariusz: Polsko-rosyjska rywalizacja o oświatę na ziemiach białoruskich na przełomie XIX-XX wieku. Biatorus. Zesz. Hist. Nr 23: 2005 s. 148-155.

142. TOMASZEWICZ Andrzej: Pomoc społeczna dla młodzieży szkół średnich w guberni kaliskiej (1866-1914). [W:] Historia, społeczeństwo, gospodarka. Pod red. Stefana Pytlasa i Jarosława Kity. Lódź 2006 s. 132-147.

143. UBERMAN Marta: Nauczanie rysunku w ludowych szkołach Galicji doby autonomicznej. Zesz. Nauk. Uniw. Rzesz. Nr 24: Ser. Pedagog.: Pedagogika i Psychologia. [Z.] 2: 2004 s. 165-174, streszcz., sum.

144. WAJDA Kazimierz: Studenci z Prus Zachodnich i Wschodnich na uniwersytecie w Getyndze (1815-1914). [W:] Nad Bałtykiem, Pregołą i Łyną. XVI-XX wiek. Księga pamiątkowa poświęcona jubileuszowi 50-lecia pracy naukowej profesora Janusza Jasińskiego. Red. Zenona Rondomańska. Olsztyn 2006 s. 228-238.

145. WĄSACZ Jolanta: Edukacja muzyczna w gimnazjach Stanisławowa w XIX i na początku XX wieku. [W:] Musica Galiciana. Kultura muzyczna Galicji w kontekście stosunków polsko-ukraińskich (od doby piastowsko-książęcej do roku 2000). T. 9. Pod red. Leszka Mazepy. Rzeszów 2006 s. $197-209$.

146. WESOŁOWSKA Sylwia: Materiały do dziejów szkolnictwa elementarnego w powiecie gryfickim do połowy XIX wieku. [W:] Trzebiatów - spotkania pomorskie - 2005 r. Pod red. Janiny Kochanowskiej. Wołczkowo k. Szczecina 2006 s. 81-91.

147. WIELEK Jan: Kto i jak uczył? Z dziejów szkolnictwa na ziemi limanowskiej. Małopolska. [T.] 4: 2002 s. 175-185.

W XIX w.

148. WLAŹLAK Władysław Piotr: Działalność oświatowa ks. Ludwika Zaborskiego w powiecie pilickim (1817-1821). Nasza Przeszłość. [T.] 105: 2006 s. 141-162, sum.

149. WOJTKOWSKI Marek: $Z$ dziejów szkolnictwa na Kujawach wschodnich w okresie rewolucji 1905-1907. Zap. Kuj.-Dobrz. T. 20: 2005 s. 19-34. 
150. WÓJCIK Zbigniew [Jerzy]: Szkoły techniczne przy Gimnazjum i Liceum Wołyńskim w Krzemieńcu. Acta Univ. Wr. No 2933: Wrocławskie Studia Wschodnie. [T.] 10: 2006 s. 129-144, rez., sum.

Lata $1805-1832$.

151. WRÓBLEWSKA Teresa: Geschichte der Bildungs- und Erziehungsarbeit der Polnischen gesellschaftlichen Organisationen in Pommern in den Jahren 1871-1914. Übers. Manfred Heinemann. Warszawa 2005 Elipsa ss. 227, il.

Wyd. pol. pt.: Polskie organizacje na Pomorzu Gdańskim w latach 1871-1914. Działalność w służbie oświaty, wychowania i kultury. Warszawa 1989.

152. ZAPALOWA Kazimiera: 50 lat z Żeromskim. Zwierzenia kustosza. Kielce 2005 Agencja JP ss. 272, il. + dysk optyczny (CD).

Muzeum Lat Szkolnych Stefana Żeromskiego w Kielcach.

153. ŹRÓDŁA do dziejów nauczania domowego dzieci polskich w XIX i początku XX wieku. $\mathrm{Z}$ bibliografią adnotowaną pamiętników i wyborem literatury pedagogicznej. Pod red. Krzysztofa Jakubiaka [i in.]. Bydgoszcz 2005 Wydaw. Uniw. Kazimierza Wielkiego ss. 374, il.

\section{Okres 1918-1939}

154. BOROWIECKA Anna: „Życie Włocławka i Okolicy” 1926-1931. Miesięcznik poświęcony sprawom społecznym, ekonomicznym, oświatowym i artystycznym. Zap. Kuj.-Dobrz. T. 20: 2005 s. $171-188$.

155. DOBROWOLSKI Rafał: Akademicka młodzież obozu narodowego w Lublinie w latach 1919-1939. Toruń 2006 Adam Marszałek ss. 285, il.

156. DOROSZEWSKI Jerzy: Działalność Polskiej Macierzy Szkolnej na Lubelszczyźnie w latach 1918-1939. Prz. Hist.-Ośw. R. 49: 2006 nr 3/4 s. 117-125.

157. DWORECKA Teresa: Formy opieki nad matką i dzieckiem w Warszawie na łamach miesięcznika "Opiekun Społeczny", wydawanego w latach 1936-1939. Medycyna Nowożytna. T. 12: 2005 z. $1 / 2$ s. $181-200$, sum., Zsfg.

158. GLIMOS-NAGÓRSKA Anna: Zarys monograficzny chorzowskich szkół powszechnych (1922-1939). Torun 2006 Stow. Oświatowców Pol. Oddz. ss. 75, il. Stow. Oświatowców Pol., Ogólnopol. Centrum Doskonalenia Nauczycieli Historii w Toruniu.

159. GRZYWACZ Andrzej: Szkolnictwo akademickie i nauka leśna. [W:] Z dziejów Lasów Państwowych i leśnictwa polskiego 1924-2004. T. 1: Okres międzywojenny. Red. nauk. t. 1 Jerzy Wiśniewski. Warszawa 2006 s. 75-124.

160. GUZEWICZ Wojciech: Działalność oświatowo-wychowawcza Akcji Katolickiej w międzywojennej diecezji łomżyńskiej. Rocz. Teol. T. 53: 2006 z. 4 s. 45-65, sum.

161. JAROSZUK Teresa: Żywa szkoła. O nowy model szkoły i wychowania w międzywojennej Polsce. Olsztyn 2006 Studio Poligrafii Komputerowej „SQL” ss. 167, nlb. 1. 
162. JUŚKO Edmund: Wpływ szkolnictwa ludowego autonomicznej Galicji na kształt polskiej szkoły powszechnej w latach 1918-1922. Lublin 2006 Wydaw. KUL ss. 293, tabl. 16, il., sum. KUL Jana Pawła II. Wydz. Nauk Hum. Katedra Dydaktyki Historii i Historii Szkolnictwa.

163. KAWIORSKI Marek: Kultura muzyczna w szkole w okresie międzywojennym. [W:] Mozaika powiatu pińczowskiego. T. 1. Pod red. Henryka Kawiorskiego. Kielce 2006 s. 300-40.

164. KOŁTUN Weronika Barbara: Sieć i organizacja szkół powszechnych w powiecie zamojskim w latach 1918-1939. Prz. Hist.-Ośw. R. 49: 2006 nr 3/4 s. 175-187.

165. KOZERA Andrzej: Edukacja w polskiej myśli politycznej (1918-1939). Kielce 2006 Akad. Świętokrzyska im. Jana Kochanowskiego. Wydz. Zarządzania i Admin. Inst. Nauk Polit.; Zakł. Poligraf.-Wydawniczy „U Poety” ss. 552.

166. MACA£A Jarosław: Wokół problematyki wychowania w nurcie katolickim myśli politycznej II RP. Prz. Hist.-Ośw. R. 49: 2006 nr 1/2 s. 89-103.

167. MAJMESKUŁ MASTALERZOWA Zofia: Moje wspomnienia. Wspomnienia pierwszej absolwentki Wydziału Prawa Uniwersytetu Jagiellońskiego. Oprac. Urszula Perkowska. Krak. Rocz. Archiw. [T.] 12: 2006 s. 217-232, sum.

Autorka żyąca w 1. 1899-1984, studiowała w Krakowie w 1. 1918/19-1922/23.

168. MARCINKIEWICZ-GOLAŚ Anna: Praca kulturalno-oświatowa w oddziałach Ochotniczej Legii Kobiet (1918-1922). [W:] W dolinie Bugu, Styru i Słuczy. Wołyń w najnowszej historii Polski. (Wybrane zagadnienia). Red. nauk. Jarosław Rubacha. Piotrków Trybunalski 2005 s. 303-317.

169. [OLSZOWIEC Stefan]: Rok z życia studenta Uniwersytetu Stefana Batorego w Wilnie 1938 r. [Wyd.] Renata Olszowiec. Piotrk. Studia Pedag. T. 12: 2006 s. 59-65.

170. PACZKOWSKI Stefan: Z dziejów dokształcania zawodowego we Włocławku do 1939 roku. Zap. Kuj.-Dobrz. T. 20: 2005 s. 59-89.

171. PIETRASZCZYK Mariola: Oświata w pierwszych latach niepodległości. Piotrk. Studia Pedag. T. 12: 2006 s. 37-43.

172. REZMER Waldemar: Szkolnictwo artyleryjskie i strzeleckie w Toruniu 1920-1939. [W:] Wojsko i kultura w dziejach Polski i Europy. Księga jubileuszowa profesora Piotra Matusaka w 65. rocznicę urodzin. Praca zbiorowa. Pod red. Rafała Dmowskiego [i in.]. Siedlce-Warszawa 2006 s. 298-308.

173. SAMSONOWSKA Krystyna: Szkolnictwo i oświata hebrajska w województwie krakowskim w latach 1918-1939. Rocz. Kom. Nauk Pedag. T. 58: 2005 [dr.:] 2006 s. 5-17, sum.

174. SANOJCA Karol: Rola lwowskiego Państwowego Wydawnictwa Książek Szkolnych w realizacji polityki oświatowej Drugiej Rzeczypospolitej. [W:] Kraków - Lwów. Książki, czasopisma, biblioteki. T. 8. Pod red. Haliny Kosętki. Kraków 2006 s. 102-110.

175. SKELNIK Julian M.: Centrum Wyższych Studiów Wojskowych 1923-1933. Gdynia 2006 Armagedon ss. nlb. 2, 48, nlb. 4, il.

176. SOLAK Anita: Szkolnictwo żydowskie we Włocławku w latach 1918-1939. Zap. Kuj.-Dobrz. T. 20: 2005 s. 35-57. 
177. SREBRAKOWSKI Aleksander: Sprawa Wacławskiego. Przyczynek do historii relacji polsko-żydowskich na Uniwersytecie Stefana Batorego w Wilnie. Prz. Wsch. T. 9: 2005/2006 [dr.:] 2006 z. 3 s. $575-601$.

Ukamienowanie Stanisława Wacławskiego przez Żydów podczas zamieszek studenckich w 1931 r.

178. STANKIEWICZ Zdzisław: Działalność seminariów nauczycielskich na północno-wschodnich kresach Rzeczypospolitej w latach 1919-1939. Torun 2006 Adam Marszałek ss. 290, il.

179. STINIA Maria: Lwowska Biblioteczka Pedagogiczna - między teorią a praktyką nauczycielską. [W:] Kraków - Lwów. Książki, czasopisma, biblioteki. T. 8. Pod red. Haliny Kosętki. Kraków 2006 s. 111-118.

Seria wydawnicza, ukazująca się w 1. 1936-1939.

180. SZCZEPAŃSKI Janusz: Młodzież szkolna w wojnie 1920 roku. [W:] Bitwa warszawska 1920 roku w obronie niepodległości. Pod red. nauk. Janusza Odziemkowskiego. Warszawa 2006 s. $181-194$.

181. SZMYD Kazimierz: $Z$ dziejów Narodowego (tajnego) Uniwersytetu Ukraińskiego we Lwowie (1919-1926). Prz. Hist.-Ośw. R. 49: 2006 nr 1/2 s. 73-88.

182. ŚLUSARCZYK Magdalena: Kwestia edukacyjna w okresie międzywojennym. [W:] Z zagadnień historii pracy socjalnej w Polsce i w świecie. Pod red. Agnieszki Małek, Krystyny Slany, Izabeli Szczepaniak-Wiechy. Kraków 2006 s. 129-138.

183. UMIŃSKI Wacław: Zakład Wychowawczy im. ks. Siemaszki w okresie międzywojennym. Nasza Przeszłość. [T.] 105: 2006 s. 295-303.

W Czernej k. Krzeszowic i Krakowie.

184. WROBEL Ralph Michael: Konflikt niemiecko-polski według kroniki szkoły i gminy Kierpień 1918-1925. Ziemia Prudn. 2004 s. 70-75.

Toż w jęz. niem.: Der deutsch-polnische Konflikt nach der Schul- und Gemeindechronik von Kerpen 1918-1925. Tamże s. 76-81.

185. WYSOCKI Tomasz: Struktura narodowościowo-wyznaniowa uczniów szkół średnich w II Rzeczypospolitej w roku szkolnym 1937/1938. Prz. Hist.-Osw. R. 49: 2006 nr 3/4 s. 95-115.

186. ZABIEROWSKI Marek: Utworzenie gimnazjum w Nadwórnej. Działalność gimnazjum w roku szkolnym 1936-37. Ziemia Prudn. 2002 s. 30-33.

\section{Okres 1939-1945}

187. BOĆKOWSKI Daniel: Radzieckie szkolnictwo w obwodzie białostockim w świetle dokumentów partyjnych 1939-1941. Studia z Dz. Rosji i Europy Środk.-Wsch. T. 41: 2006 s. 173-180.

188. DIETRICH Edward, Litwiniak Feliks: Szkolenie i szkoły wojskowe w I Rejonie „Marianów-Brzozów” VII Obwodu „Obroża” Okręgu Warszawskiego Armii Krajowej. Legionowo 2004 Koło nr 1 „Brzozów” ŚZŻ AK ss. 24.

Rec.: Ziułkowska-Karnicka Katarzyna, Rocz. Legion. T. 2: 2006 s. 348-349.

189. GÓRAL Jan: Szkolnictwo niemieckie w okupacyjnym powiecie piotrkowskim (1939-1944). Piotrk. Zesz. Hist. T. 6: 2004 s. 175-186. 
190. GROCHOWINA Sylwia: Szkolnictwo niemieckie w Okręgu Rzeszy Gdańsk-Prusy Zachodnie a latach 1939-1945 (obszar II RP). Dzieje Najn. R. 38: 2006 [nr] 4 s. 227-232.

Autoreferat pracy doktorskiej.

191. GRZYWACZ Andrzej: Szkolnictwo i nauki leśne podczas okupacji. [W:] Z dziejów Lasów Państwowych i leśnictwa polskiego 1924-2004. T. 1: Okres międzywojenny. Red. nauk. t. 1 Jerzy Wiśniewski. Warszawa 2006 s. 271-296.

192. KRONIKA ukraińskiej ludowej szkoły III stopnia im. Tarasa Szewczenki, jako źródło do dziejów Przemyśla pod okupacją sowiecką (1939-1941). [Wyd.] Ewa Grin-Piszczek. Rocz. Hist.-Archiw. T. 18: 2004 s. 281-297, sum., Zsfg., zmëst.

193. KRÓL Bolesław jun.: W walce o polską szkołę. Tajne nauczanie w okresie okupacji niemieckiej na obszarze Obwodu Włoszczowskiego AK. Niepodl. i Pam. R. 13: $2006 \mathrm{nr} 2$ s. 65-90.

194. OLSTOWSKI Przemysław: Oświata polska i niemiecka w Toruniu w latach 1920-1939. [W:] Historia Torunia. T. 3 cz. 2: W czasach Polski Odrodzonej i okupacji niemieckiej (1920-1945). Pod red. Mariana Biskupa. Toruń 2006 s. 311-378.

195. ULMAN Tadeusz: Tajne nauczanie w Albigowej podczas okupacji. [W:] Przed wiekami, przed laty... Koncepcja, oprac. i red. Andrzej Lobaza. Albigowa 2005 s. 99-105.

196. WIĄCEK Zdzisław: Historia tajnego nauczania na Baranowszczyźnie w okresie okupacji hitlerowskiej. Rocz. Miel. T. 7/8: 2004/2005 [dr.:] 2006 s. 305-308.

Wspomnienia.

197. WOŚ Halina, Woś Mirosław: Oficjalne szkolnictwo na terenie Generalnego Gubernatorstwa w okresie II wojny światowej. [W:] Przed wiekami, przed laty... Koncepcja, oprac. i red. Andrzej Lobaza. Albigowa 2005 s. 96-98.

198. ZIELIŃSKI Zbigniew: Tajne nauczanie w powiecie częstochowskim i radomszczańskim w latach 1939-1945. Niepodl. i Pam. R. 13: 2006 nr 1 s. 215-221.

199. ZIÓŁKOWSKI Bogdan: Tajne nauczanie i konspiracyjna działalność kulturalna na Kujawach wschodnich i w ziemi dobrzyńskiej (powiat lipnowski) w latach 1939-1945. Włocławek 2006 Włocławskie Tow. Nauk,; Lega ss. 179, il.

200. ZIÓŁKOWSKI B.: Tajne nauczanie w Kowalu i obwodzie kowalskim w latach 1939-1945. Ziemia Kuj. T. 19: 2006 s. 77-91.

201. ZIÓŁKOWSKI B.: Walka o polską oświatę i kulturę na Kujawach wschodnich i w ziemi dobrzyńskiej w latach 1939-1945. Cz. 2. Region. Zap. Kuj.-Dobrz. T. 20: 2005 s. 91-118.

Cz. 1. Tamże. T. 19: 2004.

\section{Okres 1945-1989}

202. APANEL Danuta: Sanatoria i prewentoria dla dzieci na Pomorzu Środkowym w latach 1945-1975. [W:] Z dziejów zdrowia publicznego. Pod red. Jana Nosko. Łódź 2006 s. 465-478.

203. BOBIK Bogumiła: Odbudowa i kształtowanie szkolnictwa na Gómym Śląsku po zakończeniu II wojny światowej. [W:] Zakończenie wojny na Górnym Śląsku. Pod red. Zygmunta Woźniczki. Katowice 2006 s. 285-304. 
204. CIEŚLIŃSKI Antoni: Początki szkolnictwa polskiego $w$ powiecie gryfickim $w$ latach 1945-1948. [W:] Trzebiatów - spotkania pomorskie - 2005 r. Pod red. Janiny Kochanowskiej. Wołczkowo k. Szczecina 2006 s. 92-105.

205. CZAJKOWSKI Michał: Lokietka 17. Nadwarc. Rocz. Hist.-Archiw. Nr 13: 2006 s. $181-182$.

Wspomnienia z Seminarium Duchownego w Gorzowie z 1. 1950-1953.

206. DOMAGALA Jarosław: Szkoła Umuzykalniająca Ludowego Instytutu Muzycznego w Kutnie (1946-1949). Kutn. Zesz. Region. T. 10: 2006 s. 237-254.

207. DUDA Jerzy: Nauczyciele $\mathrm{z}$ kresów wschodnich II Rzeczypospolitej - pionierami oświaty na Śląsku Opolskim. Prz. Hist.-Ośw. R. 49: 2006 nr 3/4 s. 127-135.

208. FRANKóW Piotr: Szkolnictwo gorzowskie po roku 1975. [W:] Gorzów Wielkopolski w 60-leciu 1945-2005. Materiały z konferencji naukowej, Gorzów Wielkopolski 3 czerwca 2005 roku. Red. Dariusz Aleksander Rymar, Juliusz Sikorski. Gorzów Wielkopolski 2005 s. 227-252.

209. GANCEWSKA Iwona: Krzysztof Celestyn Mrongowiusz w podręcznikach do szkoły podstawowej po 1945 roku. Mrag. Studia Hum. T. 6/7: 2004/2005 [dr.:] 2006 s. 288-300, Zsfg.

210. GŁĘBOCKI Henryk: Służba Bezpieczeństwa wobec studentów w Krakowie (1980-1981). [W:] Między Sierpniem a Grudniem. „Solidarność” w Krakowie i Małopolsce w latach 1980-1981. Pod red. Tomasza Gąsowskiego; przy współpr. Barbary Klich-Kluczewskiej i Janusza Mierzwy. Kraków 2006 s. 45-64.

211. GOLON Mirosław: Młodzież polska na studiach cywilnych i wojskowych w ZSRR w okresie klasycznego stalinizmu (1950-1956/1957). Polska 1944/45-1989. [T.] 7: 2006 s. 61-121.

212. GRĘDZIK-RADZIAK Agnieszka: Szkolnictwo polskie na Białorusi w latach 1944-1948. Acta Univ. Wr. No 2933: Wrocławskie Studia Wschodnie. [T.] 10: 2006 s. 205-217, rez., sum.

213. HOSZOWSKA Mariola: Między teorią a praktyką nauczania historii w Polsce (1956-1966). Zesz. Nauk. Uniw. Rzesz. Nr 30: Ser. Socjol.-Hist: Historia. [Z.] 2: 2005 s. 44-60.

214. KACZMAREK Ewa: Eliminacja zakonów z życia publicznego. Ograniczenie działalności charytatywnej i opiekuńczo-wychowawczej w latach 1945-1956. Rocz. Teol. T. 53: 2006 z. 4 s. 67-86, sum.

215. KARPYZA Witold: Moje wspomnienia o Małym Seminarium Duchownym w Gorzowie. Nadwarc. Rocz. Hist.-Archiw. Nr 13: 2006 s. 183-184.

Pierwsze lata po II wojnie światowej.

216. KMIECIK Tadeusz: Organizacja systemu szkolnictwa wojskowego w latach 1945-1955. [W:] Abiit, non obiit. Studia historyczne poświęcone pamięci profesora Andrzeja Czarnika. Pod red. Zenona Romanowa. Słupsk 2006 s. 205-224.

217. KOŁAKOWSKI Andrzej: Materialne uwarunkowania kształtowania się systemu opieki całkowitej nad dzieckiem opuszczonym w województwie gdańskim w latach 1945-1949. Rocz. Gdań. T. 66: 2006 s. 101-116, sum.

218. KOSIŃSKI Krzysztof: Oficjalne i prywatne życie młodzieży w czasach PRL. Warszawa 2006 Rosner \& Wspólnicy ss. 416, il. 
219. KRÓLIKOWSKA Wanda: Codzienność zorganizowanego wypoczynku dzieci i młodzieży w Polsce w latach 1956-1970: program i realizacja. [W:] Życie codzienne w PRL (1956-1989). Pod red. Grzegorza Miernika i Sebastiana Piątkowskiego. Radom-Starachowice 2006 s. 75-96.

220. [KULCZYŃSKI Stanisław]: Pierwszy rok akademicki w powojennym Wrocławiu. [Wyd.] Romuald Gelles. Zbliż. Pol. - Niem. [R. 13]: 2003 z. 3 s. 62-76.

Zawiera: Mowa J.M. Rektora Uniwersytetu i Politechniki we Wrocławiu prof. dra Stanisława Kulczyńskiego, wygłoszona na uroczystym otwarciu Uniwersytetu i Politechniki w dniu 9 czerwca 1946 r.; Mowa Jego Magnificencji prof. dra Stanisława Kulczyńskiego, Rektora Uniwersytetu i Politechniki we Wrocławiu, wygłoszona w czasie uroczystej inauguracji roku akademickiego 1946/1947 w dniu 9 grudnia 1946 r. w auli Politechniki.

221. LESIAKOWSKI Krzysztof: Laicyzacja młodzieży w hufcach i brygadach Powszechnej Organizacji „Służba Polsce” (1948-1953). Dzieje Naj. R. 38: 2006 [nr] 2 s. 55-80, sum.

222. MARCINIAK Waldemar: Stalinizacja oświaty na przykładzie miasta Włocławka. Prz. Hist.-Oświat. R. 49: 2006 nr 1/2 s. 139-156.

Lata 1945-1956.

223. MICHALSKI Andrzej: Statystyczne ujęcie wybranych problemów szkolnictwa artystycznego w Polsce w latach 1945-1965. [W:] Historyczna i pedagogiczna problematyka muzyki. Zbiór rozpraw. Pod red. Elżbiety Szubertowskiej. Bydgoszcz 2006 s. 19-33.

224. MYŚLECKI Wojciech: Nauczyciele akademiccy Wrocławia w walce o wolną Polskę. [W:] Nauka i polityka. Jubileusz siedemdziesięciolecia urodzin profesora Andrzeja Wiszniewskiego. Red. merytoryczna Janusz Szafran. Wrocław 2005 s. 107-119.

225. OSIŃSKI Zbigniew: Nauczanie historii w szkołach podstawowych w Polsce $w$ latach 1944-1989. Uwarunkowania organizacyjne oraz ideologiczno-polityczne. Toruń 2006 Dom Wydaw. Duet ss. 271.

226. PLEWKA Czesław: Przemiany w oświacie szczecińskiej w latach 1945-1989. Struktury i programy. [W:] Od Polski Ludowej do III RP w Unii Europejskiej. Pomorze Zachodnie 1945-2005. Materiały z sesji naukowej, 29 kwietnia 2005 r. Pod red. Kazimierza Kozłowskiego, Adama Wątora, Edwarda Włodarczyka. Szczecin 2006 s. 215-240.

227. POGORZALA Ewa: Szkolnictwo białoruskie w Polsce po II wojnie światowej. [W:] Polska - Białoruś. Problemy sąsiedztwa. Pod red. Henryka Chałupczaka, Elżbiety Michalik. Lublin 2005 s. $145-154$.

228. POGORZAŁA E.: Szkolnictwo hebrajskie w Polsce w latach 1946-1949. Prz. Hist.-Ośw. R. 49: $2006 \mathrm{nr} 3 / 4$ s. $137-156$.

229. PRÓCHNIAK Leszek: Precz z komunistyczną juntą. Strajk studencki w Lodzi 14-15 grudnia 1981 r. Biul. IPN. $2006 \mathrm{nr}$ 11/12 s. 49-52.

230. REDER Jerzy: Katolicki Uniwersytet Lubelski w latach 1946-1950. Wspomnienia z okresu studiów. Summarium. R. 34: 2005 [dr.:] 2006 s. 233-244.

231. SADOWSKI Wojciech: Wspomnienia z Seminarium. W szkole spokoju, radości i rozterek. Nadwarc. Rocz. Hist.-Archiw. Nr 13: 2006 s. 189-194.

Niższe Seminarium Duchowne w Gorzowie Wielkopolskim, 1. 50. XX w. 
232. SKARBEK Piotr: Początki szkolnictwa średniego na ziemi prudnickiej i jego organizatorzy (1945-1947). Ziemia Prudn. 2002 s. 55-66.

Zawiera też biogramy.

233. STRAJKOWALIŚMY w WOSP. Biul. IPN. 2006 nr 11/12 s. 110-121.

Wspomnienia uczestników strajku w Wyższej Oficerskiej Szkole Pożarnictwa w Warszawie, XI-XII 1981 r.

234. SZAL Eugeniusz: Rola rejonowych konferencji pedagogicznych w dokształcaniu i doskonaleniu zawodowym nauczycieli w okręgu rzeszowskim w latach 1945-1948. Zesz. Nauk. Uniw. Rzesz. Nr 24: Ser. Pedagog.: Pedagogika i Psychologia. [Z.] 2: 2004 s. 196-209, streszcz., sum.

235. SZNAJDER Andrzej: „Desantowcy” z Bytomia. Biul. IPN. $2006 \mathrm{nr}$ 11/12 s. 122-130.

Wspomnienia na temat konspiracyjnej działalności bytomskich licealistów w stanie wojennym.

236. SZUBA Ludwik Stanisław: Powszechna Organizacja „Służba Polsce” jako narzędzie pracy i indoktrynacji młodzieży w latach 1948-1955. Lublin 2006 TN KUL ss. 305, nlb. 6, tabl. 9, il., sum. Tow. Nauk. KUL Jana Pawła II. (Prace z Historii Szkolnictwa w Polsce; t. 14) (Źródła i Monografie; 298).

237. SZULAKIEWICZ Władysława: Historia oświaty i wychowania w Polsce 1944-1956. Kraków 2006 Wydaw. WAM ss. 311, nlb. 20, il., Zsfg.

238. ŚLĘCZKA Ryszard: Powstanie i działalność krakowskiego Oddziału Towarzystwa Burs i Stypendiów [Rzeczypospolitej Polskiej]. Rocz. Kom. Nauk Pedag. T. 58: 2005 [dr.:] 2006 s. 19-28, r,s.

Lata 1946-1951.

239. WŁODARCZYK Edward: Od Akademii Handlowej do Uniwersytetu Szczecińskiego. [W:] Od Polski Ludowej do III RP w Unii Europejskiej. Pomorze Zachodnie 1945-2005. Materiały z sesji naukowej, 29 kwietnia 2005 r. Pod red. Kazimierza Kozłowskiego, Adama Wątora, Edwarda Włodarczyka. Szczecin 2006 s. 167-178.

240. ŻWIRKO Janina: Oświata. [W:] Czaplinek 1945-2005. 60-ta rocznica powrotu do Macierzy. Cz. 1. Czaplinek 2005 s. 27-36.

\section{Okres $1989-2006$}

241. DZIEDZIC Zenon: Katolickie Towarzystwo Służby Dzieciom - 15 lat. [Suwałki 2006] KTSD Zarząd Kraj. - Artekst Usługi Wydawnicze Kazimierz Sobecki ss. 68, il.

242. GNITECKI Janusz: Nadzieje, złudzenia i dylematy reformy oświatowej w Polsce. Rocz. Pedag. T. 29: 2006 s. 7-25, abstr.

243. GOŁĘBIOWSKA Anna: Miejsce NSZZ „Solidarność” we współczesnej edukacji historycznej oraz w świadomości historycznej młodzieży Śląska Opolskiego. Pr. Uczestn. Studium Dokt. T. 8: Historia: 2006 s. $37-44$.

244. KALINOWSKA Jan Ryszard: Kryształowy jubileusz. Zarys monograficzny z okazji 15-lecia Płockiego Towarzystwa Oświatowego. Płock 2006 Płockie Tow. Oświatowe ss. 182, nlb. 2, il.

245. RODZINA Szkół im. Jana Pawła II. W pierwszą rocznicę przejścia Jana Pawła II do Domu Ojca. Red. Zbigniew Gumiński. Radom 2006 Fama - Zbigniew Gumiński ss. 615, nlb. 1, il. 


\section{Oświata polonijna}

246. CHALUPCZAK Henryk: Działalność oświatowa Polaków na terenie Westfalii i Nadrenii w okresie międzywojennym. [W:] Schimanski, Kuzorra i inni. Polacy w Zagłębiu Ruhry 1870/71-1945. Pod red. Dittmara Dahlmanna, Alberta S. Kotowskiego, Zbigniewa Karpusa. Toruń 2006 s. 224-234.

247. GRĘDZIK-RADZIAK Agnieszka: Nauczanie języka polskiego w przedszkolach w ramach białoruskiego systemu oświatowego. Rocz. Wsch. Nr 12: 2006/2007 [dr.:] 2006 s. 9-17.

Od 1994 r.

248. ORMAN Elżbieta: „Energiczna pedagogika” Karoliny Lanckorońskiej. Organizacja studiów dla żołnierzy 2. Korpusu we Włoszech w latach 1945-1947. Zesz. Nauk. UJ. [Nr] 1284: Prace Hist. Z. 133: 2006 s. 109-125, sum.

249. PLESKOT Patryk: Studenci polscy we Francji 1945-1949. Prz. Hum. R. 50: $2006 \mathrm{nr} 3$ s. $137-152$.

250. SZYMAŃSKI Józef: Stan i sytuacja szkolnictwa polonijnego w Belgii (1940-2000). Studia Polonijne. T. 27: 2006 s. 183-209, sum.

251. ŚMIEJA Florian: Koło Polonistów Polskiego Uniwersytetu na Obczyźnie. Arch. Emigracji. $2006 \mathrm{nr} 1 / 2$ s. $367-370$.

W 1. 1952-1955.

252. TURKOWSKI Romuald: Szkoła Nauk Politycznych i Społecznych w Londynie - nieudana próba kształcenia kadr dla polskiego uchodźstwa niepodległościowego - lata 40-te do 60-tych XX wieku. Rocz. Hist. MHPRL. Nr 22: 2006 s. 149-173.

\section{DZIEJE SZKóŁ RóŻNYCH STOPNI}

\section{Szkoły podstawowe i zakłady wychowawcze}

253. ALEKSANDER Tadeusz: Dzieje Szkoły Podstawowej nr 17 im. Kurierów Sądeckich w Nowym Sączu - Porębie Małej (1902-2005). Rocz. Sqdec. T. 34: 2006 s. 106-156.

254. BADZIOCH Halina, Bladoszewska Wiesława: Historia szkoły podstawowej w Wicku. Biul. Hist. [Lęborskie Bractwo Hist.]. Nr 29: 2006 s. 43-54.

Otwarta w $1946 \mathrm{r}$.

255. BOBER Renata, Strzyżowska Bogumiła: Minęło tyle lat... 120-lecie Szkoły Podstawowej w Drabiniance, 50-lecie Szkoły Podstawowej $\mathrm{nr}$ 11, 10-lecie nadania szkole imienia [gen. Stanisława Maczka]. Warszawa-Rzeszów 2006 Agencja Wydaw. Ad Oculos ss. 175, nlb. 1, il.

XIX-XX w.

256. BUBLEWICZ Jacek: Szkoła ewangelicka w Dźwierznie w XIX wieku. Koczała 2004 Jacek Bublewicz ss. 36, il. (Z Dziejów Koczały i Okolic). 
257. CHRZĄSTEK Barbara: Historia kiedrzyńskiej szkoły. Almanach Częstochowy. [T. 19]: 2006 s. $181-188$.

Lata 1901-2000.

258. GIZA Jerzy: Szkoła młodych Piłsudczyków, czyli o patriotyzmie, którym co pokolenie musi się zarazić. Sowiniec. Nr 29: 2006 s. 145-159.

Niepubliczna Szkoła Podstawowa nr 1 im. Józefa Piłsudskiego w Krakowie, powstała w 1989 r.

259. GOGOLA Zdzisław: Dzieje szkoły w Ołpinach. Kraków 2005 Wydaw. Poligrafia Salezjańska ss. 346 , il.

XIX-XXI w.

260. [JĘDRZEJCZYK Maria]: Wieś syna Jana. Krótka historia wsi i placówki oświatowej w Janowicach napisana przez Marię Jędrzejczyk nauczycielkę Szkoły Podstawowej w Janowicach na 110-lecie szkoły. Janowice 2006 Wydaw. Triada Wojciech Wicher ss. 107, nlb. 1, il.

261. JUBLEUSZ XXX-lecia Szkoły Muzycznej I i II stopnia im. I. J. Paderewskiego w Koninie 1974-2004. Red. Krzysztof Pydyński, Urszula Kozłowska. Poznań 2004 Rhytmos ss. 253, il. Szkoła Muzyczna I i II stopnia im. I. J. Paderewskiego w Koninie.

Z treści: Wardęcka-Gościńska Alicja: Historia powstania Państwowej Szkoły Muzycznej I stopnia w Koninie s. 25-32; Kozłowska U.: Szkoła Muzyczna I i II stopnia im. I. J. Paderewskiego w Koninie - funkcjonowanie i oddziaływanie publicznej placówki kształcenia artystycznego w mieście i regionie na przestrzeni 30 lat jej istnienia s. 33-60; Gościńska Danuta: Ogólnopolski Konkurs Pianistyczny w Koninie. Rys historyczny i rola w środowisku pianistycznym kraju s. 61-71; Wardęcka-Gościńska A.: Witold Miron Jan Friemann [1880-1970]. Życie, twórczość, związki z Koninem, listy s. 73-112; Kłaniecki Marek: Muzyka liturgiczna w świetle dokumentów Kościoła s. 113-120; Sawa Edyta: Karol Lipiński - wirtuoz, kompozytor, pedagog s. 149-155; Rzanna-Szczepaniak Ewa: Zalożenia polityki kulturalnej PPR i PZPR formułowane w latach 1945-1956 s. 215-249.

262. JUREK Anna: Szkoła podstawowa w Załużu i jej kronika. Bieszczad. [T.] 12: 2005/2006 [dr.:] 2006 s. 126-133.

$\mathrm{XIX}-\mathrm{XX}$ w.

263. KIELAK Katarzyna, Turowska Dorota: Historia Szkoły Podstawowej w Duczkach. Rocz. Wotom. T. 2: 2006 s. 119-128.

Lata 1908-2005.

264. KOLODZIEJCZYK Joanna, Lewandowska Alina: Księga pamiątkowa Zespołu Szkoły Podstawowej i Gimnazjum w Kajetanowie 1962-2006. Kajetanów 2006 Wydaw. „Bogart” ss. 72, nlb. 2, tabl. 24, il.

265. KOROLEWSKA Elżbieta: Historia i działalność Domu Pomocy Społecznej dla Dzieci w Elblągu przy ul. Gen. Józefa Bema 8. Studia Elbl. T. 5: 2003 s. 197-203, Zsfg.

Od 1947 r.

266. KSIĘGA Protokołów Komitetu Budowy 7-klasowej Publicznej Szkoły Powszechnej w Złotej. [Wyd.] Andrzej Tarka. [W:] Mozaika powiatu pińczowskiego. T. 1. Pod red. Henryka Kawiorskiego. Kielce 2006 s. 200-212.

267. KUŹMIŃSKA Aleksandra: Szkoła przy Oporowskiej. Historia Zespołu Szkół nr 1 im. Stanisława Staszica w Kutnie. Kutno 2006 Agencja Rozwoju Regionu Kutnowskiego ss. 412, il.

Rec.: Urbaniak Andrzej, Kutn. Zesz. Region. T. 10: 2006 s. 510-512.

268. MARYNIARCZYK Agnieszka: Szkoła w Witowie. [W:] 400 lat Witowa. 1606-2006. Praca zbior. pod red. Andrzeja Maryniarczyka. Witów-Lublin 2006 s. 161-191. 
269. NOWICKA Halina: Rys historyczny Szkoły Podstawowej nr 1 w Wołominie. Rocz. Wotom. T. 2: 2006 s. $95-118$.

Lata 1918-2005.

270. „ODKRYJMY nasze korzenie”. O przeszłości i dniu dzisiejszym Olszewki i Lubaszcza. Oprac. pod red. Grażyny Kamińskiej; teksty G. Kamińska, Sławomir Łaniecki, Renata Strugała-Wiśniewska, Daria Gruszczyńska, Ryszard Kamiński. Olszewka-Sępólno Krajeńskie 2004 Firma Usługowo-Wydawnicza „Daniel” Ewa Wierzchucka ss. 67, il. Stow. na Rzecz Rozwoju Olszewki i Lubaszcza.

$\mathrm{Z}$ treści: Dzieje szkoły w Olszewce s. 21-38.

271. PAŃSTWOWA Szkoła Muzyczna I stopnia nr 5 im. Henryka Wieniawskiego w Warszawie. Monografia jubileuszowa 1946-2006. Zespół red. Beata Niepiekło [i in.]. Warszawa 2006 Państ. Szkoła Muzyczna I st. nr 5 im. H. Wieniawskiego; Wydaw. Didasko ss. 117, nlb. 2, il.

272. RACLAWSKI Kazimierz: Uśmiech przez łzy. Dom Dziecka Stowarzyszenia Rodzina Policyjna w latach 1932-1946 Skolimów-Sochaczew-Szymanów. Teresin 2004 Wydaw. „Perła” ss. 239, il.

273. RYŁKO Jolanta, Ryłko Andrzej: Dzieje szkoły w Rajczy. Rajcza 2004 Jolanta Ryłko ss. 92, il.

Szkoła Podstawowa nr 1 im. ks. Józefa Tischnera, XIX-XXI w.

274. SAKS Zofia: Szkoła Podstawowa nr $4 \mathrm{w}$ Wołominie w latach 1935-2000. Rocz. Wotom. T. 2: 2006 s. $149-188$.

275. SKARYSZEW: dzieje, ludzie, jarmarki końskie. Red. Włodzimierz Płowiec; zespół red. Renisława Domagała [i in.]; współpr. i konsult. Władysława Banaszkiewicz [i in.]. Sycyna-Radom 2006 Wydaw. Stow. Oświatowego Sycyna; Wydaw. Inst. Technologii Eksploatacji ss. 342, nlb. 1, tabl. 14, il., sum. (Biblioteka Sycyńska; t. 26).

Z treści: Edukacja i wychowanie: Kaczkowski Witold, Turuk Urszula: Szkoła w Skaryszewie s. 97-138; Bukalska Justyna, Kowalik Jolanta, Nosowska Edyta: Publiczna Szkoła Podstawowa w Makowcu s. 139-141; Domagała Łucja: Historia szkoły w Makowie s. 142-162; Domagała R.: Szkoła Podstawowa w Chomentowie s. 163-169; Niewczas Tomasz: Szkoła Podstawowa w Odechowie s. 170-173; Gwizd Wiesław: Publiczna Szkoła Podstawowa w Wólce Twarogowej s. 173-178; Lipiec Małgorzata: Publiczna Szkoła Podstawowa w Modrzejowicach s. 179-181; Majak Grażyna, Wójtowicz Bożena: Szkoła W Dzierzkówku Starym s. 182-190; Wiszniewska Jadwiga: Publiczna Szkoła Podstawowa w Sołtykowie s. 191-193; Jabłońska Jolanta: Przedszkole w Skaryszewie s. 194-198.

276. [STO sześćdziesiąt] 160 lat szkoły w Halembie. Zespół red. Maria Lorens, Antoni Ratka, Dorota Świtała-Trybek. Ruda Śląska 2001 Tow. Przyj. Rudy Śląskiej; Szkoła Podstawowa nr 24 im. Powstańców Śląskich ss. 102, nlb. 2, il.

Szkoła Podstawowa nr 24 im. Powstańców Śląskich w Rudzie Śląskiej.

Z treści: Ratka A.: Dzieje szkoły w latach 1840-1951 (do końca samodzielności gminy Halemba) s. 7-35; Szkoła we wspomnieniach pracowników i wychowanków s. 47-66; Kalendarium s. 67-76; Wykaz kierowników, dyrektorów, nauczycieli, pracowników administracyjno-technicznych oraz charakterystycznych roczników absolwentów szkoły s. 97-103.

277. SZKOŁA Podstawowa Nr 3 w Sławnie. Zarys dziejów 50-lecia (1956-2006). Red. Maria Poprawska i Jan Sroka. Sławno 2006 Szkoła Podstawowa Nr 3; Margraf ss. 91, il.

278. TRADYCJA i współczesność. 50 lat Szkoły Podstawowej im. św. Maksymiliana Kolbego w Teresinie. Pod red. Anny Parol; oprac. zespół w składzie Renata Ćwiklińska, A. Parol, Emilia Włodarczyk. Teresin-Łowicz 2006 Za sprawą Szkoły Podstawowej im. św. M. Kolbego; Poligrafia ss. 176 , tabl. 8 , il. 
279. TRĄBSKA Ewa: Monografia Zespołu Szkół Specjalnych im. Marii Grzegorzewskiej w Zawierciu. Zawiercie 2002 Zespół Szkół Specjalnych ss. 76, il.

Po 1945 r.

280. WIANECKA Aneta: Z dziejów Szkoły Podstawowej nr 1 w Strzelcach Krajeńskich w latach 1945-2004. Nadwarc. Rocz. Hist.-Archiw. Nr 13: 2006 s. 131-136.

281. WITECKA Zdzisława: 140 lat szkoły w Samsonowie. Samsonów 2003 Tow. Ziemi Samsonowskiej ss. 78 , nlb. 1, il.

Zespół Szkoły Podstawowej, Przedszkola i Gimnazjum im. Jana Pawła II w Samsonowie w XIX-XXI w.

282. WULTAŃSKI Jerzy: Zarys historii Szkoły Podstawowej nr 1 w Brodnicy. Brodnica 2004 Multi B. Grzybowska - T. Siekierski ss. 126, nlb. 2, il.

XIX-XXI w.

283. ZARYS dziejów Szkoły Podstawowej i Gimnazjum w Białce Tatrzańskiej 1856-2006. Praca zbiorowa. Red. Eugeniusz Madeja. Białka Tatrzańska 2006 Zespół Szkół Szkoła Podstawowa i Gimnazjum ss. 227, il.

Z treści: Wstęp s. 7-8; Madeja E.: Trudne początki białczańskiej szkoły s. 9-25; Madeja E.: Dzieje białczańskiej szkoły w latach 1914-1945 s. 26-38; Madeja Urszula, Madeja E.: Historia Szkoły w latach 1945-2006 s. 39-72; Kowalczyk Józef, Madeja E.: Życie społeczno-kulturalne Szkoły s. 73-81; Kowalczyk J.: Z dziejów białczańskiego harcerstwa s. 82-87; Iwan Paweł: $Z$ dziejów sportu szkolnego w białczańskiej szkole s. 95-106; Uczniowie wspominają swoją białczańską szkołę s. 107-115; Kierownicy i dyrektorzy Szkoły w Białce Tatrzańskiej s. 116-130; Madeja E.: Nauczyciele zatrudnieni w białczańskiej szkole s. 131-141; Wykaz absolwentów Szkoły Podstawowej w Białce Tatrzańskiej w latach 1949-2006 s. 146-206; Wykaz absolwentów Gimnazjum w Bialce Tatrzańskiej w latach 2002-2006 s. 207-226.

284. ZESPÓE Szkół Gminy Kościan - Przedszkole i Szkoła Podstawowa w Starym Luboszu. Praca zbiorowa. Pod red. Iwony Gaertig i Katarzyny Kalemby. Kościan 2005 PWU Tęcza ss. 48, il.

\section{Szkoły średnie ogólnokształcące}

285. BARTCZAK Zenon: Liceum Ogólnokształcące im. Bolesława Chrobrego w Piotrkowie Trybunalskim 1675-2000. Dzieje, wychowankowie, absolwenci. Piotrków Trybunalski 2005 Zenon Bartczak ss. 448, il., rez., sum., Zsfg. (Biblioteka, Piotrków 800; 1).

286. BOHUSZEWICZ Janusz: Ta nasza młodość... Na pamiątkę jubileuszu 60-lecia Liceum Ogólnokształcącego im. Stanisława Staszica w Połczynie Zdroju. Toruń 2006 Adam Marszałek ss. 187 , nlb. 2 , il.

287. DWORNICKA Barbara, Wróbel Teresa: Zespół Szkół Licealnych w Zwoleniu. [W:] Ziemia Jana Kochanowskiego. Powiat zwoleński. Pod red. Henryka Bednarczyka, Bogusławy Jaworskiej, Jerzego Kozińskiego. Sycyna-Radom 2006 s. 138-149.

288. DZIEDZICTWO - współczesność. T. 2. Zespół red. Beata Kautsch, Zofia Mulińska, Anna Ufniarz. Chełm 2006 Wydaw. TaWa Taurogiński Waldemar; na zlec. IV Liceum Ogólnokształcącego w Chełmie ss. 84, il. IV Liceum Ogólnokształcące im. Doktor Jadwigi Młodowskiej w Chełmie.

Antologia wspomnień, wydana z okazji 15-lecia IV Liceum Ogólnokształcącego w Chełmie i II Zjazdu Absolwentów, 23-24 września 2006 r.

T. 1.2000. 
289. FIOŁKA Krzysztof: Biskupiak - historia i teraźniejszość. Lublin 2004 „Bramka” Studio Komputerowo-Wydawnicze ss. 121, nlb. 1, il.

XXI Liceum Ogólnokształcące im. św. Stanisława Kostki w Lublinie, XX-XXI w.

290. JUBILEUSZ Liceum Jana Kochanowskiego w Radomiu 1912-2002. Oprac. zespół pod przewodn. Adama Wasilewskiego. Radom 2002 Kom. Organizacyjny 90-lecia Liceum Jana Kochanowskiego; współpr. Inst. Technologii Eksploatacji ss. 256, il.

Z treści: Kwiecień Marcin: Dzieje szkoły od powstania do wybuchu II wojny światowej (1912-1939) s. 5-16; Orzechowska Elżbieta: Lata okupacji i tajne nauczanie (1939-1945) s. 17-23; Jakubska Czesława: Tuż po wojnie s. 24-27; Jeżmańska Maria, Kwiecień M.: Powojenne dzieje szkoły (1945-1991) s. 28-35; Semik Karol: Współczesne Liceum Kochanowskiego w kalejdoskopie zdarzeń lat 1998-2002 s. 36-45; Karolak Grażyna: Nauczyciele Gimnazjum i Liceum Jana Kochanowskiego w Radomiu w latach 1912-2002 s. 46-53; Wspomnienia, wspomnienia s. 96-133; Żyszczyńska Irena: Pokolenia absolwentów Szkoły Kochanowskiego s. 134-136; Beresińska Maria, Nowak Krystyna: Lista absolwentów szkoły 1918-2002 s. 137-230.

VI LO w Radomiu.

291. KARTKI. Zespół red. Ewa Betiuk [i in.]. Chełm 2006 Na zlec. I LO im. S. Czarnieckiego; Drukarnia Kresowa ss. 83, nlb. 1, il. I Liceum Ogólnokształcące im Stefana Czarnieckiego w Chetmie.

Dzieje I LO w Chełmie w XX w.

292. KSIĘGA jubileuszowa rocznika maturalnego 1951 Liceum i Gimnazjum im. Jana Kasprowicza w Inowrocławiu. Oprac. zespół w składzie Tadeusz Ćwikliński [i in.]. Inowrocław 2003 Stow. Wychowanków Gimnazjum i Liceum im. Jana Kasprowicza w Inowrocławiu ss. 259, nlb. 1, il.

Rec.: Chorążyczewski Waldemar, Ziemia Kuj. T. 17: 2004 s. 241-243.

293. KSIĘGA pamiątkowa Zespołu Szkół Ogólnokształcących im. Mikołaja Kopernika w Kołobrzegu, 1945-2005. Zespół red. Krystyna Bremborowicz [i in.]. Kołobrzeg 2005 ZSO; Wydaw. Kamera ss. 319, il.

Z treści: Skorupiński Józef: Kopernik w roku 60-tych urodzin s. 7-14; Kowalczyk Beata: 60 lat historii Kopernika s. 15-28; Kalendarium s. 85-141; Lista nauczycieli ZSO od początku do chwili obecnej s. 143-153; Wykaz absolwentów ZSO 1945-2005 s. 155-205; Wspomnienia, refleksje, opinie s. 215-281.

294. KUFFEL Romana Krystyna: Jagiellończyków biografie niepospolite. Płock 2006 Samizdat Zofii Łoś ss. 223, nlb. 1, il.

Liceum Ogólnokształcące im. Władysława Jagiełły w Płocku, XX-XXI w.

295. KUKIZ Tadeusz: 60-lecie Gimnazjum i Liceum Męskiego w Prudniku. Bolesław Hadaczek - historyk literatury kresowej. Ziemia Prudn. 2006 s. 165-166.

296. KWINTA Damian: Z historii II Liceum Ogólnokształcącego im. Stefanii Sempołowskiej w Prudniku. Ziemia Prudn. 2003 s. 50-54.

Od 1927 r.

297. LAUDAN Elżbieta, Chylak Agnieszka: Liceum Ogólnokształcące im. Marii Skłodowskiej-Curie w Rawie Mazowieckiej. 60-lecie szkoły, 1945-2005. Łódź 2005 Wydaw. Papier-service Wojciech Grochowalski ss. 51, il.

298. LICEUM Ogólnokształcące im. Janusza Korczaka w Więchorku 1945-2005. Red. Leszek Skaza, Mirosław Wojciechowski. Sępólno Krajeńskie-Wałdowo 2005 Firma Usługowo-Wydaw. „Daniel” Ewa Wierzchulska ss. 70, il. 
299. ŁOPUSZAŃSKI Tadeusz: Rydzyna. Gimnazjum im. Sułkowskich (1928-1936). Poznań 2001 Kuratorium Oświaty ss. 236, nlb. 2, tabl. 42, il.

Repr., oryg.: Rydzyna 1937.

300. MACTE animo. W stulecie XI Liceum Ogólnokształcącego imienia Mikołaja Reja w Warszawie. Red. prowadzący Katarzyna Sałkiewicz. Warszawa 2006 XI Liceum Ogólnokształcące imienia Mikołaja Reja ss. 183, nlb. 1, il.

Z treści: Kalendarium s. 5-14; Zarys historii szkoły [1906-2006] s. 17-72; Tradycje i współczesność s. 75-120; Dyrektorzy s. 120; Nauczyciele s. 121-129; Absolwenci s. 144-184.

301. PANIENKI z Saskiej Kępy. Wspomnienia uczennic XII Liceum Ogólnokształcącego im. Marii Skłodowskiej-Curie (1930-1964). Red. Małgorzata Malewicz. Warszawa 2006 Oficyna Wydaw. Lośgraf ss. 365 , nlb. 31, il.

W Warszawie.

Z treści: Malewicz M.: Przedmowa s. 5-7; Dłużej nie istnieje niż istniała. Rys historyczny. Oprac. M. Malewicz s. 9-16; My i Oni: Marczakówna-Ryczkowska Teresa: „Róg Brackiej i Konopackiej...” s. 19-32; Zarębska-Kratochwil Ewa: List z Tasmanii s. 33-37; Zarębska-Kratochwil E.: Spotkanie po latach s. 38-42; Kosewska-Mirkiewicz Krystyna: A może by tak na AWF... s. 43-44; Szczawińska-Sikorska Dorota: Szkoła w latach stalinowskich s. 45-56; Kowrygo Danuta: W pięćdziesiąt lat później... s. 57-58; Jaworska-Gomólińska Małgorzata (Małata) „Więcej serca!” - „Więcej grozy!” czyli „Skłodowska” z zacięciem artystycznym s. 70-89; Iwanicka-Litońska Ewa: „Babi jazgot słyszę!” s. 90-91; Strumpf-Józefowicz Angelika: Pedagodzy z Saskiej Kępy s. 97-99; Materska Maria: „Lekko obłąkana Francuzica” s. 102-104; Dobrowolska-Śliwińska Jolanta: Wypracowanie. Nasza klasa, ja i inni s. 111-120; Dobrowolska-Śliwińska J.: Migawka s. 121; Dobrowolska-Śliwińska J.: Z mojego pamiętnika - 27 stycznia 1988 s. 122; Dobrowolska-Śliwińska J.: 40 lat minęło jak jeden dzień s. 123-127; Dobrowolska-Śliwińska J.: Z mojego pamiętnika - 23 stycznia 1988 s. 130; Siwecka Agnieszka: Pani Jadwiga Daabowa s. 131-133; Siwecka A.: Obóz narciarski w Sobieszowie s. 134-136; Siwecka A.: Spacer w Łazienkach s. 137-142; Siwecka A.: Lekcje gimnastyki s. 143-146; Siwecka A.: Trzydziestolecia matury absolwentek klas XI „b” i „c" z 1958 r. s. 147-149; Malewicz M.: Korneliusz Nepos i jaszczurka s. 150-182; Kucicka-Litwin-Staszewska Elżbieta: „W Skłodowskiej nie będzie wam źle...” s. 185-187; Kucicka-Litwin-Staszewska E.: Myszka s. 188-193; Konaszkiewicz Zofia: Moja szkoła s. 194-221; Szubert-Jarosińska Iza: Oni s. 222-233; Owczarska-Józefowicz Bożenna: Ostatni gaszą światło s. 234-247; Dawnych wspomnień czar: Fragmenty kroniki szkolnej z 1961/1962 r. s. 250-257; Oni. Biografie nauczycieli: Życiorys Jadwigi z Moraczewskich Zanowej 1894(?)-1964. Oprac. Maria Urban-Kalicińska s. 286-291; Szczawińska-Sikorska D.: Jan Ehrenfeucht 1901-1994 s. 292-309; Życiorys Pani Zofii Herfurtowej (28.02.1891-1.05.1965). Oprac. Barbara Suraga s. 310-315; Grażyna z Sokołowskich Lipińska 1900(?)-1995 s. 316-317; Irena Straszyńska 1891-2.02.1963 s. 318-320; Źyciorys siostry Consolaty - Barbary Krupczak urszulanki Unii Rzymskiej [ur. 1923] s. 321-322; Wykaz nauczycieli Państwowego (Gimnazjum i) Liceum nr $12 \mathrm{im}$. Marii Skłodowskiej-Curie w Warszawie s. 323-327; Alfabetyczny wykaz nauczycieli s. 329-333; Wykaz absolwentek s. 335-365.

302. RYBARCZYK Piotr: Od Königliches Friedrich-Gymnasium zu Bromberg do Państwowego Gimnazjum Klasycznego w Bydgoszczy. [W:] Polacy i Niemcy w Bydgoszczy. Sympozjum, 20 kwietnia 2006. Muzeum Okręg. im. Leona Wyczółkowskiego w Bydgoszczy. Red. Iwona Loose. Bydgoszcz 2006 s. 85-87.

Toż w jęz. niem. s. 171-173.

303. RYBARCZYK P.: Z dziejów gimnazjum przy Weltzienplatz/placu Wolności. Od Königliches Friedrich-Gymnasium zu Bromberg do Państwowego Gimnazjum Klasycznego w Bydgoszczy (1817-1939). Kron. Bydg. T. 27: 2005 [dr.:] 2006 s. 97-150.

304. SIKORSKI Juliusz: Niższe Seminarium Duchowne w Gorzowie (1946-1960). Powstanie i likwidacja. Nadwarc. Rocz. Hist.-Archiw. Nr 13: 2006 s. 169-179. 
305. [STO] 100 lat „Kościuszki”. Pod red. Anety Kolańczyk; współpr. Elżbieta Piszczorowicz-Mondra, Jarosław Wujkowski. Kalisz 2005 Edytor ss. 460, il.

Treść: Mydlach Piotr: Pierwsze dziesięciolecia (1905-1945) s. 13-60; Miklas Agata: Lata 1945-1980 s. 61-68; Hołysiak Irena: Lata 1980-1994 s. 69-74; Woźniak Maria: Lata 1994-1999 s. 75-82; Krzyżanowska-Koszycka Teresa, Rudowicz Małgorzata: IV Liceum Ogólnokształcące im. S. Sempołowskiej. „Wspomnienia serdeczne" s. 83-106; Stowarzyszenie Wychowanków Liceum Ogólnokształcącego im. T. Kościuszki w Kaliszu. Oprac. M. Woźniak s. 107-121; Majchrzak Beata: Poczet dyrektorów Szkoły Handlowej, Gimnazjum i Liceum im. T. Kościuszki s. 127-149; Wspomnienia o nauczycielach s. 151-189; Wybitni absolwenci s. 191-226; Dyśko Wojciech, Margules Józef: Zawsze wierni. Sylwetki żołnierzy-absolwentów s. 227-279; Dyśko W.: Lista Katyńska absolwentów s. 279-288; Majchrzak B., Majchrzak Wacław: Zwycięzcy olimpiad i konkursów przedmiotowych s. 289-321; Skrzypczyńska Karolina, Wujkowski Jakub: Klub Europejczyka „Polonus” w latach 1993-2004 s. 323-328; Wujkowski Jarosław: II Liceum Ogólnokształcące im. T. Kościuszki w latach 1999-2005 s. 331-377; Dyrektorzy i nauczyciele szkoły s. 381-392; Lista wychowanków s. 393-457.

Rec.: Kosman Marceli, Rocz. Kalis. T. 32: 2006 s. 330-332.

306. SZKOLNE pokolenia. Rys historyczno-wspomnieniowy. Pod red. Aleksandra Czarneckiego; przy współudz. Alicji Głowackiej. Wąbrzeźno 2006 ZSO ss. 240, il. Zespół Szkół Ogólnokształcących w Wąbrzeźnie.

Z treści: Czarnecki A., Stenzel Michał: Królewskie Progimnazjum Realne s. 7-13; Pocierznicka Jolanta, Świgońska Ewa: Dwudziestolecie międzywojenne s. 15-30; Czarnecki A., Różycka Joanna: Spuścizna okupacyjna (1939-1945) s. 41-45; Różycka J.: Powojenna odbudowa s. 47-61; Piotrowski Włodzimierz: Wspomnienia s. 61-69; Maguza Marta: Czas stalinizacji s. 71-81; Klimek Henryk, Gulda Mieczysław: Wspomnienia s. 81-86; Głowacka A., Matuszewska Marika: Dyrektorskie autorytety s. 87-104; Künstler Bolesław: Na przełomie wieków s. 117-128; Oskwarek Aleksandra, Walkiewicz Inga: Zygmunt Działowski [1843-1878] sylwetka patrona s. 135-140; Becker Paweł, Kruk Alicja: Zestawienia sumaryczne s. 141-144; Künstler B.: Absolwenci szkoły s. 169-224.

307. WOJCIECHOWSKI Krzysztof Jan: Widziane z Cafe Gruz. Liceum im. Mikołaja Reja w Warszawie. Apogeum stalinizmu 1950-1955. Pruszków 2006 Wydaw. M.M. ss. 771, il.

308. WÓJCIK Gabriel: Prywatne Gimnazjum i Liceum OO. Bernardynów w Radecznicy w okresie 1944-1950. [W:] Radecznica. Ośrodek życia religijnego i społeczno-kulturowego. Red. Roman Jusiak. Kalwaria Zebrzydowska-Kraków 2006 s. 191-207.

309. WYSPIAŃCZYCY. 95 lat Gimnazjum i Liceum im. Stanisława Wyspiańskiego w Mławie. VIII Zjazd Wychowanków, 7-9 czerwca 2002 r. Zespół red. Przemysław Kubiński [i in.]. Mława 2002 Stow. Absolwentów i Wychowanków Liceum i Gimnazjum im. Stanisława Wyspiańskiego ss. 223 , nlb. 2 , il.

310. Z DZIEJÓW Kamiennej Góry. Aus der Geschichte Landeshuts. Tł. na jęz. niem. Tomasz Pryll. Kamienna Góra 2005 Muzeum Tkactwa Dolnośląskiego ss. 139, il.

Z treści: Lubieniecki Jan: Państwowe Gimnazjum i Liceum w Kamiennej Górze w latach 1945-1959 s. 72-78 Lubieniecki J.: Staatliches Gymnasium und Lyzeum in Landeshuts 1945-1959 s. 129-139.

311. ZARYS dziejów IX Liceum Ogólnokształcącego im. Mikołaja Kopernika w Lublinie. Pod red. Agnieszki Mądrakiewicz-Stanek. Lublin 2002 Wydaw. Copernicus IX L.O. im. Mikołaja Kopernika ss. 88 , il.

Po 1945 r.

312. ZIMIŃSKA Urszula: Szkoła patriotyzmu. 160 lat szkoły w Radzyminie. Studia i Mater. do Dz. Pow. Wotom. Nr 2: 2006 s. 471-473.

Liceum im. Cypriana Kamila Norwida. 


\section{Szkoły zawodowe}

313. GRYGORCEWICZ Bartosz: Gimnazjum Pszczelarskie w Byczeniu w latach 1946-1952 w świetle materiałów archiwalnych Archiwum Państwowego we Wrocławiu oraz Oddziału w Kamieńcu Ząbkowickim. [W:] Wpływ opactwa cystersów na rozwój Kamieńca Ząbkowickiego. Red. Lidia Wiśniewska. Kamieniec Ząbkowicki 2006 s. 47-57.

314. JANICKA Ewa, Głowacz Roman: Rys historyczny Szkoły Rolniczej w Przemyślu. Rocz. Przemyski. T. 42: 2006 z. 5 s. 113-119, sum.

Od 1944 r.

315. JUBILEUSZ państwowego szkolnictwa muzycznego w Białymstoku: 1936, 1961, 1972, 1989: 19-21 listopada 2002 r. Red. Krystyna Ambrożek [i in.]. Białystok 2002 Zespół Szkół Muzycznych im. Ignacego Paderewskiego ss. 62, il.

316. KU PAMIĘCI potomnym. Przeszłość i teraźniejszość Zespołu Szkół Mechaniczno-Elektrycznych im. Kazimierza Pułaskiego w Częstochowie 1926-2006. Red. nauk. Zbigniew Grządzielski, Kazimierz Marczyk. Częstochowa 2006 Zespół Szkół Mechaniczno-Elektrycznych im. K. Pułaskiego - Rada Rodziców ss. 508, tabl. 135, il.

Z treści: Grządzielski Z.: Historia Szkoły Rzemieślniczo-Przemysłowej Okręgowego Towarzystwa Rzemieślniczego w Częstochowie w latach 1926-1945 s. 12-43; Grządzielski Z., Marczyk Kazimierz: Ksztaltowanie się modelu szkoły zawodowej w okresie powojennym s. 44-53; Wołyniec Dominik: Historia warsztatów szkolnych s. 54-60; Stan obecny szkoły z uwzględnieniem rysu historycznego s. 62-105; Kazimierz Pułaski patron szkoły s. 164-199; Sport w szkole s. 200-203; Szkoła we wspomnieniach s. 329-359; Życiorysy nauczycieli i osób współpracujących ze szkołą. Oprac. Marianna Lojewska, Alina Tkaczyk s. 361-370; Indeks nazwisk nauczycieli-pracowników Zasadniczej Szkoły Metalowej, Zespołu Szkół Mechanicznych i Zespołu Szkół Mechaniczno-Elektrycznych w latach 1951-2005, sporządzony na podstawie spisów nauczycieli znajdujących się w sekretariacie szkoły. Oprac. Ewa Otrąbek, Aneta Jończyk-Kubuśka s. 371-382; Indeks nazwisk nauczycieli zawodu pracujących w Warsztatach Szkolnych przy ul. Wolności 17 (1951-1997). Oprac. E. Otrąbek, A. Jończyk-Kubuśka s. 383-386; Kadra kierownicza ZSME w Częstochowie i placówek oświatowych, do których sięga tradycja szkoły. Oprac. Zbigniew Grządzielski, K. Marczyk, A. Jończyk-Kubuśka s. 387-388; Indeks nazwisk absolwentów od 1929 roku. Oprac. Beata Wroniecka s. 391-482.

317. [OSIEMDZIESIĘCIOLECIE] 80-lecie Szkoły Rolniczej im. Józefa Piłsudskiego w Okszowie 1923-2003. Wydawnictwo okolicznościowe. Zespół red. Anna Ląkocy-Lemieszek, Marta Szkliniarz, Adam Cichowicz. Okszów 2003 Zespół Szkół Rolnicze Centrum Kształcenia Ustawicznego ss. 144, il.

318. PRZEPIÓRKA Teresa, Krajewska Magdalena: Zespół Szkół Rolniczo-Technicznych im. Bohaterów Walki z Faszyzmem w Zwoleniu. [W:] Ziemia Jana Kochanowskiego. Powiat zwoleński. Pod red. Henryka Bednarczyka, Bogusławy Jaworskiej, Jerzego Kozińskiego. Sycyna-Radom 2006 s. $150-164$.

319. RUDNICKA Marzena: Od prywatnej koedukacyjnej szkoły handlowej do Zespołu Szkół Ekonomicznych im. Stanisława Staszica (1940-2005). Studia i Mater. do Dz. Pow. Wolom. Nr 2: 2006 s. $479-493$.

W Wołominie.

320. RYKWA Izabella, Biernat Joanna: $Z$ dziejów Zespołu Szkół Samochodowych im. Stanisława Syroczyńskiego w Lublinie. Wspomnienia jubileuszowe 1914-2004. Lublin 2004 Zespół Szkół Samochodowych im. Stanisława Syroczyńskiego ss. 177, il. 
321. SZCZYPKA Danuta, Špila Lubomir: Księga pamiątkowa Zespołu Szkół Gastronomiczno-Hotelarskich im. Władysława Reymonta w Wiśle 1936-2006. Wisła 2006 Zespół Szkół Gastronomiczno-Hotelarskich im. W. Reymonta ss. 200, il.

322. WALCZAK Krzysztof, Wańka Danuta: Pół wieku Technikum Budowy Fortepianów im. Gustawa Arnolda Fibigera w Kaliszu (1954-2004). Kalisz 2004 Kaliskie Tow. Przyj. Nauk ss. 147, nlb. 1, il. Kom. Organizacyjny IV Zjazdu Wychowanków Technikum Budowy Fortepianów w Kaliszu.

323. ZARAZIŃSKA Hanna: Zespół Szkół Ekonomicznych im. Stanisława Staszica w Wołominie. Rocz. Wolom. T. 2: 2006 s. 129-148.

Lata 1940-2005.

324. ZESPÓŁ Szkół Technicznych im. Tadeusza Kościuszki w Leżajsku. Kom. red. Artur Bucior [i in.]; wspólpr. Jan Buszta [i in.]. Leżajsk 2006 Podkarpacki Inst. Książki i Marketingu ss. 592 , nlb. 3 , il.

120 lat szkolnictwa zawodowego w Leżajsku 1886-2006.

Treść: Z dziejów szkoły s. 11-99; Życie szkoły s. 100-337; Warsztaty szkolne s. 338-349; Wspomnienia s. 350-401; Wykaz nauczycieli, pracowników i absolwentów szkoły s. 402-576.

\section{Zakłady kształcenia nauczycieli (z wyjątkiem szkół wyższych)}

325. JAKÓBOWSKI Jan: Wspomnienia o dobrej szkole - Liceum Pedagogicznym w Bydgoszczy. Prz. Hist.-Ośw. R. 49: $2006 \mathrm{nr}$ 1/2 s. 105-116.

Lata 1920-1964.

\section{Szkoły wyższe}

\section{Akademia Ekonomiczna im. Oskara Langego we Wrocławiu}

326. Księga 50-lecia Wydziału Inżynieryjno-Ekonomicznego. Red. Waldemar Podgórski. Wrocław 2004 Wydaw. Akad. Ekonom. im. Oskara Langego ss. 197, il.

Z treści: Ładoński Wiesław: Z kart historii Akademii Ekonomicznej s. 11-15; Znamierowska Teresa, Podgórski Waldemar, Moraszka Anna: Zarys historii Wydziału Inżynieryjno-Ekonomicznego (1954-2004) s. 21-54; Rozmowy i wywiady s. 139-150; Absolwenci i pracownicy o sobie i wydziale s. 151-181; Wspomnienia o tych, którzy odeszli s. 184-197.

\section{Akademia Kijowsko-Mohylańska}

327. CHYNCZEWSKA-HENNEL Teresa: Akademia Kijowsko-Mohylańska: historia i współczesność. Prz. Hum. R. 50: 2006 nr 1 s. 59-68, sum.

XVIII-XIX w. 


\section{Akademia Medyczna im. Karola Marcinkowskiego w Poznaniu}

328. [OSIEMDZIESIĘCIOPIĘCIOLECIE] 85-lecie studiów w zakresie farmacji i 25-lecie studiów w zakresie analityki medycznej w Poznaniu. Księga pamiątkowa. T. 1-2. Poznań 2005 Wydaw. Nauk. Akad. Medycznej im. Karola Marcinkowskiego ss. 386, i1.; 186, il. (Farmacja i Analityka Medyczna w Poznaniu; t. 1-2).

Rec. [T. 1]: Wysakowska Beata, Kw. Hist. Nauki i Techn. R. 51: 2006 nr 2 s. 274-276.

\section{Akademia Medyczna w Gdańsku}

329. WAJDA Zdzisław: $\mathrm{Z}$ dziejów gdańskiej chirurgii akademickiej i dyscyplin zabiegowych oraz anestezjologii w 60-leciu Akademii Medycznej w Gdańsku (1945-2005). Tł. na jęz. ang. Paweł Dobrowolski. Gdańsk-Pelplin 2006 Bernardinum ss. 211, nlb. 3, il.

Współwyd.: From the history of Gdañsk's academic surgery, operative disciplines and anaesthesiology at the 60th anniversary of the Medical University of Gdańsk.

Tekst równol. pol., ang.

\section{Akademia Medyczna we Wrocławiu}

330. GOŁĘBIOWSKI Andrzej: Represje okresu wojennego przyszłych studentów Wydziału Medycyny Weterynaryjnej we Wrocławiu - rocznik 1947-1951. [W:] Wybitni lekarze weterynaryjni na przestrzeni dziejów w świecie i w Polsce, historia zawodu lekarsko-weterynaryjnego, zainteresowania pozazawodowe lekarzy weterynaryjnych. Sesja naukowa $\mathrm{z}$ udziałem gości zagranicznych, Wrocław-Kobyla Góra, 20-22 czerwca 2003 r. Oprac. Jacek Króliński. Wrocław 2003 s. $23-25$.

\section{Akademia Ostrogska}

331. KEMPA Tomasz: Akademia i Drukarnia Ostrogska. Biały Dunajec-Ostróg 2006 Ośr. „Wołanie z Wołynia” ss. 77. (Biblioteka „Wołania z Wołynia”; t. 46).

XVI-XVII w.

\section{Akademia Rolnicza w Szczecinie}

332. PAIASZ Lech: 50 lat Akademii Rolniczej w Szczecinie. Kron. Szczec. 2005. Nr 24: 2006 s. $149-153$.

Zal. w 1954 r. 


\section{Akademia Zamojska}

333. TERNES Jerzy: Profesorowie cudzoziemscy w Akademii Zamojskiej. [W:] Ważna obecność. Przedstawiciele państw i narodów europejskich wśród mieszkańców międzyrzecza Bugu i Pilicy w XVII-XIX wieku. Materiały sesji naukowej, Radom, 30 listopada 2006 r. Pod red. Artura Góraka i Krzysztofa Latawca. Radzyń Podlaski-Radom 2006 s. 27-36.

\section{Katolicki Uniwersytet Lubelski}

334. GALASZEWSKA-CHILCZUK Dorota: Polityka państwa wobec Katolickiego Uniwersytetu Lubelskiego w latach 1944-1968. Pam. i Sprawiedl. 2006 nr 2 s. 39-68, sum.

335. MADAEA Tadeusz, Narecki Krzysztof: Filologia klasyczna w Katolickim Uniwersytecie Lubelskim w latach 1918-2004. Red. K. Narecki. Lublin 2006 Wydaw. KUL ss. 124, nlb. 1, tabl. 12, il. KUL. Inst. Filologii Klasycznej.

336. WAŻNIEWSKI Władysław: Katolicki Uniwersytet Lubelski w świetle dokumentów władz państwowych Polski powojennej (1944-1970). [W:] Dzieje - wojsko - społeczeństwo. Studia ofiarowane prof. dr. hab. Edwardowi Pawłowskiemu z okazji sześćdziesiątej piątej rocznicy urodzin. Red. nauk. Henryk Hermann, Stanisław Jaczyński, Hubert Królikowski. Siedlce 2006 s. $117-130$.

\section{Politechnika Białostocka}

337. [TRZYDZIEŚCI] 30 lat Wydziału Architektury Politechniki Białostockiej. Konferencje i wystawy. Białystok 2006 Wydz. Architektury Politech. Białostockiej ss. 245, il., sum.

Zawiera gł. streszczenia materiałów bloku konferencji naukowych, jakie odbyły się w dn. 19-20 V $2006 \mathrm{r}$.

\section{Politechnika Warszawska}

338. KSIĘGA konferencyjna. Rok jubileuszowy Wydziału Inżynierii Lądowej Politechniki Warszawskiej 1915-2005. T. 1: Referaty. Warszawa 2005 Oficyna Wydawnicza Politech. Warszawskiej ss. XI, nlb. 1, 156, nlb. 2, il., streszcz. Politech. Warszawska. Wydz. Inżynierii Lądowej.

Toż. T. 2: Referaty okolicznościowe. Warszawa 2005 ss. 89, il.

339. POPŁAWSKI Bogdan: Początki Wydziału Architektury Politechniki Warszawskiej w świetle nieznanych dotąd dokumentów. Ochrona Zabytków. R. 59: $2006 \mathrm{nr} 3$ s. 111-116, sum.

Lata 1904-1916.

340. TYRKIEL Eugeniusz: Geneza Wydziału Inżynierii Materiałowej Politechniki Warszawskiej 1970-1991. Warszawa 2002 Oficyna Wydawnicza PW ss. 375, il. (Zeszyty Historyczne Politechniki Warszawskiej; 10). 
341. TYRKIEL E.: Wydział Inżynierii Materiałowej Politechniki Warszawskiej na przełomie stuleci 1996-2002. Warszawa 2005 Oficyna Wydawnicza Politech. Warszawskiej ss. 189, il. (Zeszyty Historyczne Politechniki Warszawskiej; 11).

342. WIŚNIEWSKA Miriam, Wiśniewski Jerzy: Katedra Architektury i Planowania Wsi Politechniki Warszawskiej - 60 lat istnienia. Warszawa 2006 Oficyna Wydawnicza Politech. Warszawskiej ss. 174, il.

\section{Politechnika Wrocławska}

343. PRĘTCZYŃSKI Zenon: Wspomnienia o profesorach Wydziału Architektury Politechniki Wrocławskiej (z lat studiów 1947-1952). Wrocław 2005 Oficyna Wydaw. Politech. Wrocławskiej ss. 131 , nlb. 3 , tabl. 16 , il.

U góry s. tyt.: 60-lecie Wydziału Architektury Politechniki Wrocławskiej 1945-2005.

Wyd. 2 popr. Wrockaw 2006 ss. 152, tabl. 1, il.

\section{Szkoła Główna Handlowa}

344. HISTORIA Szkoły Głównej Handlowej 1906-2006. The history of the Warsaw School of Economics 1906-2006. Pod red. Wojciecha Morawskiego. Warszawa 2006 Szkoła G1. Handlowa. Oficyna Wydawnicza ss. 403, nlb. 1, il.

345. KALIŃSKI Janusz: Stulecie Szkoły Głównej Handlowej w Warszawie (1906-2006). Wiad. Statyst. R. 51: $2006 \mathrm{nr} 12$ s. 86-90.

\section{Uniwersytet Adama Mickiewicza w Poznaniu}

346. FĄKA Marian: Dole i niedole profesorów Uniwersytetu Poznańskiego w okresie okupacji hitlerowskiej. Pozn. Studia Teol. T. 20: 2006 s. 239-255.

\section{Uniwersytet Albertyna w Królewcu}

347. MAŁŁEK Janusz: Życie codzienne królewskiej Albertyny w początkach XIX wieku w świetle pamiętnika studenta z Pomorza Zachodniego Karola Bogumiła Rehsenera [1790-1862]. [W:] Życie codzienne na dawnych ziemiach pruskich. Ziemie pruskie w oczach polskich i obcych. Praca zbiorowa. Pod red. Stanisława Achremczyka. Olsztyn 2006 s. 158-162.

\section{Uniwersytet Gdański}

348. ANDRZEJEWSKI Marek, Mokrzecki Lech, Włodarski Józef Arno: Zarys dziejów Uniwersytetu Gdańskiego. Sześćdziesiąt lat tradycji polskiego szkolnictwa pedagogicznego i ekonomicznego na Wybrzeżu. Gdańsk 2006 Uniw. Gdański ss. 79, tabl. 16, il. 


\section{Uniwersytet Jagielloński}

349. GĄSIOROWSKI Antoni: Szamotulscy studenci na krakowskim uniwersytecie w XV i XVI wieku. [W:] Szamotuły. Karty z dziejów miasta. [Cz.] 1. Pod red. Antoniego Gąsiorowskiego. Szamotuły 2006 s. $65-97$.

350. GĄSOWSKI Tomasz: „Solidarność” Uniwersytetu Jagiellońskiego. Dzieje szesnastu miesięcy. [W:] Między Sierpniem a Grudniem. „Solidarność” w Krakowie i Małopolsce w latach 1980-1981. Pod red. Tomasza Gąsowskiego; przy współpr. Barbary Klich-Kluczewskiej i Janusza Mierzwy. Kraków 2006 s. 65-76.

351. GOMOLISZEK Joanna: Pierwsze powojenne wydawnictwa studenckie Uniwersytetu Jagiellońskiego. [W:] Kraków - Lwów. Książki, czasopisma, biblioteki. T. 8. Pod red. Haliny Kosętki. Kraków 2006 s. 97-101.

352. GRODZISKI Stanisław: Nauka i nauczanie historii prawa w Uniwersytecie Jagiellońskim (1945-2005). Nauka Pol. Potrzeby, Org. [T.] 15: 2006 s. 133-174, sum.

353. JACKOWSKI Antoni: Geografia w Uniwersytecie Jagiellońskim na przełomie XX i XXI wieku. Nauka Pol. Potrz. Org. [T.] 15: 2006 s. 197-222, sum.

354. KIELAR-TURSKA Maria: Krakowski ośrodek psychologii. Pr. Kom. Hist. Nauki. T. 7: 2006 s. 51-76.

Uzup.: Dyskusja. Tamże s. 77-79.

W XX w.

355. KIELAR-TURSKA M.: Psychologia na Uniwersytecie Jagiellońskim. Nauka Pol. Potrz. Org. [T.] 15: 2006 s. 175-195, sum.

Od 1903 r.

356. KILKA słów o działalności NSZZ „Solidarność” na Wydziale Chemii Uniwersytetu Jagiellońskiego w latach 1980-1989. Na podstawie własnych wspomnień i kolegów z Wydziału. Zebrała Teresa Życzkowska. Sowiniec. Nr 29: 2006 s. 95-100.

357. KONTUREK Stanisław J., Pawlik Wiesław W.: Katedra Fizjologii Wydziału Lekarskiego Collegium Medicum Uniwersytetu Jagiellońskiego (1849-2006). Nauka Pol. Potrz. Org. [T.] 15: 2006 s. 239-257, sum.

358. KRONIKA Uniwersytetu Jagiellońskiego za rok akademicki 2001/2002. Red. Kroniki Andrzej Kazimierz Banach. Kraków 2004 Ośr. Informacji i Promocji UJ ss. 360, il. UJ.

Toż za rok akademicki 2002/2003. Red. nacz. Kroniki A. K. Banach. Kraków 2005 ss. 339, nlb. 1, il.

Toż za rok akademicki 2003/2004. Red. nacz. Kroniki A. K. Banach. Kraków 2006 ss. 334, nlb. 1, il.

359. LEGUTKO Janusz: I Katedra Chirurgii Ogólnej i Klinika Chirurgii Gastroenterologicznej Collegium Medicum Uniwersytetu Jagiellońskiego w Krakowie. Nauka Pol. Potrz. Org. [T.] 15: 2006 s. 259-279, sum.

Dzieje od $1779 \mathrm{r}$.

360. NIEMIEC Barbara: Wszystko się jakoś pozacierało. Wysłuchała i oprac. Barbara Polak. Biul. IPN. 2006 nr $11 / 12$ s. 135-144.

Wspomnienia z 1. 80. XX w. działaczki „Solidarności” UJ. 
361. PIETRZYK Zdzisław: Studenci z Bodzentyna na Uniwersytecie Krakowskim w XVI-XVII wieku. [W:] Bodzentyn. Studia z dziejów miasta. Studies in the history of the town. Red. Krzysztof Bracha, Beata Wojciechowska. Kielce 2005 s. 111-121.

362. POPIEL Jacek: Wydział Polonistyki. Nauka Pol. Potrz. Org. [T.] 15: 2006 s. 35-57, sum.

363. SZCZEPANIAK Jan: Święcenia kapłańskie rektorów Uniwersytetu Krakowskiego z XVII i XVIII wieku. [W:] Stromata historica in honorem Romani Mariae Zawadzki. Studia historyczne ofiarowane Romanowi Marii Zawadzkiemu w 70. rocznicę urodzin. Red. Jacek Urban. Kraków 2006 s. $315-336$.

364. SZYMAŃSKA Beata: Filozofia na Uniwersytecie Jagiellońskim. Nauka Pol. Potrz. Org. [T.] 15: 2006 s. 19-33, sum.

365. WISZ Piotr: Saletyńscy studenci Uniwersytetu Jagiellońskiego. Resovia Sacra. R. 12: 2005 [dr.:] 2006 s. 191-214, sum.

Lata 1948-1954.

\section{Uniwersytet Lwowski}

366. DRAUS Jan: Uniwersytet Jana Kazimierza we Lwowie w latach 1939-1944. Pr. Kom. Hist. Nauki. T. 7: 2006 s. 105-128.

Uzup.: Dyskusja. Tamże s. 128-132.

367. LAVREC'KIJ Roman: Istorična meděevěsika na gumanětarnomu fakul'tetě L'věvs'kogo uněvversitetu v 1918-1939 rokah. [W:] Bagatokul'turne ěstorične seredovise L'vova v XIX - XX stilěttãh. Wielokulturowe środowisko historyczne Lwowa. Za red. Leonĕda Zaškěl'âka i Jerzego Maternickiego. T. 4. L'věv-Žešuv 2006 s. 449-460.

368. REDZIK Adam: Kurs Prawa Lotniczego przy Wydziale Prawa Uniwersytetu Jana Kazimierza we Lwowie (1936-1939). Rocz. Lwow. 2006 s. 43-57.

369. REDZIK A.: Wydział Prawa Uniwersytetu Lwowskiego w latach 1939-1946. Lublin 2006 TN KUL ss. 409, nlb. 7, tabl. 15, il., sum., změst. Tow. Nauk. KUL Jana Pawła II. (Źródła i Monografie; 283).

370. SZMYD Kazimierz: Uniwersytet Lwowski w dobie samookreślenia swojej tożsamości narodowej i wieloetnicznej (1868-1918). Prz. Hist.-Ośw. R. 49: 2006 nr 3/4 s. 27-39.

371. SZULAKIEWICZ Władysława: Dzieje Uniwersytetu Lwowskiego w twórczości Karola Lewickiego. [W:] Bagatokul'turne ěstorične seredovise L'vova v XIX-XX stilětttâh. Wielokulturowe środowisko historyczne Lwowa. Za red. Leoněda Zaškěl'âka i Jerzego Maternickiego. T. 4. L'věv-Žešuv 2006 s. 70-76.

\section{Uniwersytet Medyczny w Łodzi}

372. SUPADY Jerzy: Zarys historii Katedry i Zakładu Historii Medycyny i Farmacji Uniwersytetu Medycznego w Lodzi. Arch. Hist. i Filoz. Med. T. 69: 2006 z. 3/4 s. 203-206. 


\section{Uniwersytet Mikołaja Kopernika}

373. KOZLOWSKI Ryszard: Uniwersytet Mikołaja Kopernika w okresie pierwszej „Solidarności" (1980-1981). Dzieje Najn. R. 38: 2006 [nr] 4 s. 179-195, sum.

374. [SZEŚĆDZIESIECIOLECIE] 60-lecie Uniwersytetu Mikołaja Kopernika w Toruniu. Pod red. Czesława Łapicza i Witolda Wróblewskiego. Toruń 2006 Wydaw. UMK ss. 295, il.

Z treści: Wprowadzenie s. VII-XI; Michniewicz Marian: Państwowe Liceum im. J. i J. Śniadeckich w Wilnie we wspomnieniach ucznia s. 3-9; Tomczak Andrzej: Nauka i sztuka we Lwowie przed 1939 r. s. 10-14; Hübner Piotr: Nauka i szkoły wyższe II Rzeczypospolitej - system wartości s. 15-20; Supruniuk Mirosław A.: Losy profesorów Uniwersytetu Stefana Batorego po 1945 r. Społeczność akademicka USB na obczyźnie (1947-1987) s. 21-38; Biskup Marian: Wspomnienie o początkach studiów historycznych na UMK s. 41-45; Tomczak A.: Trudne początki UMK w Toruniu 1954-1956 s. 46-49; Michniewicz M.: Wypowiedź na spotkaniu panelowym zorganizowanym przez Klub Profesorów UMK w dniu 10 listopada 2004 r. s. 50-55; Polak Wojciech: Wydarzenia marca 1968 r. na Uniwersytecie Mikołaja Kopernika w Toruniu s. 59-62; Polak W.: Wydarzenia polityczne na UMK w latach 1980-1989 s. 63-91; Flik Józef: Sukcesy i porażki Wydziału Sztuk Pięknych (próba syntezy) s. 95-105; Kamińska Krystyna: Dzieje Wydziału Prawa i Administracji w latach 1945-2005 oraz Wydziału Nauk Ekonomicznych i Zarządzania UMK w latach 1968-2005 s. 106-117; Łubieńska-Iwaniszewska Cecylia: Początki Wydziału Matematyczno-Przyrodniczego Uniwersytetu Mikołaja Kopernika w Toruniu s. 118-126; Michniewicz M.: Wydział Biologii i Nauki o Ziemi w sześćdziesiątą rocznicę powstania Uczelni s. 127-137; Staszewski Jacek: Wydział Humanistyczny s. 138-144; Duczkowska-Moraczewska Henryka: Archiwum - pamięć Uczelni s. 145-152; Kuffel Jarosław: Dopóki ziarno nie obumrze s. 165-171; Maliszewski Kazimierz: Działalność Duszpasterstwa Akademickiego O.O. Jezuitów w Toruniu w latach 1963-1988 s. 172-182; Tyc Andrzej: Historia i rola Klubu Inteligencji Katolickiej w Toruniu w dziejach UMK s. 183-189; Polak W.: Działalność Służby Bezpieczeństwa wobec toruńskich Duszpasterstw Akademickich s. 190-219; Salmonowicz Stanisław: Wspomnienia o profesorach i o „salonach" toruńskich lat sześćdziesiątych i siedemdziesiątych s. 223-231; Kalembka Sławomir: Garść anegdot oraz wspomnień pośrednich i bezpośrednich o pierwszych rektorach Almae Matris Torunensis s. 232-244; Michno-Zatorska Zofia: My o anegdocie - anegdota o nas s. 245-247; Materiały do bibliografii historii Uniwersytetu Mikołaja Kopernika w Toruniu (1945-2004). [Oprac.] Monika Ostrowska s. 259-291.

\section{Uniwersytet Rzeszowski}

375. WIERZBIENIEC Marta: Wychowanie muzyczne na Uniwersytecie Rzeszowskim. Zesz. Nauk. Uniw. Rzesz. Nr 1: Ser. Stuki Piękne: Muzyka. [Z.] 1: 2002 s. 9-13.

Od 1985 r., począwszy od Wyższej Szkoły Pedagogicznej w Rzeszowie.

\section{Uniwersytet Szczeciński}

376. DĄBROWSKA Danuta: Dwadzieścia lat Uniwersytetu Szczecińskiego. Kron. Szczec. 2005. Nr 24: 2006 s. 129-138.

377. UNIWERSYTET Szczeciński. Fakty i refleksje. Praca zbior. pod red. Zbigniewa Puchalskiego. Szczecin 2006 Wydaw. „Dokument” - Oficyna Archiwum Państ.; Biuro Promocji i Informacji Uniw. Szczecińskiego ss. 103, nlb. 1, il.

$\mathrm{Z}$ treści: Wstęp s. 5-6; Tarczyński Waldemar: 20 lat - pierwszy krok w historii uniwersytetu s. 7-10; Puchalski Z.: Jubileuszowe refleksje s. 11-20; Mielcarek-Glowacka Zofia: Droga do uniwersytetu s. 21-43; Jaskot Kazimierz: Od ustawy o powołaniu Uniwersytetu Szczecińskiego do inauguracji jego działalności s. 45-52; Ra- 
kowski Mieczysław F[ranciszek]: Przed ostateczną decyzją s. 75-77; Maciszewski Jarema: Wystąpienie na forum plenarnym Sejmu 21 lipca 1984 roku s. 79-85; Dokumenty, fakty i liczby s. 87-96; Rektorzy Uniwersytetu Szczecińskiego s. 102.

\section{Uniwersytet Warszawski}

378. HULANICKI Adam: 50 lat chemii analitycznej na Wydziale Chemii Uniwersytetu Warszawskiego. Kw. Hist. Nauki i Techn. R. 51: 2006 nr 2 s. 349-361.

379. JUBILEUSZ 50-lecia Wydziału Chemii Uniwersytetu Warszawskiego 1955-2005. Red. Zbigniew Wielogórski. Warszawa 2005 Wydz. Chemii UW ss. 447, il.

Z treści: Chałasiński Grzegorz: Nasz Jubileusz s. 5-9; Władze Dziekańskie Wydziału Chemii Uniwersytetu Warszawskiego w latach 1955-2005 s. 13-14; Pamiętamy o Nich s. 17-113; Wydział Chemii, jego wczoraj... i dziś s. 117-198; Wspomnienia s. 201-388; Stopnie i tytuly s. 391-435.

Rec.: Zamecki Stefan, Kw. Hist. Nauki i Techn. R. 51: 2006 nr 2 s. 265-273.

\section{Uniwersytet Wileński}

380. LASINSKAS Povilas: Istorijos mokslas Vytauto Didžiojo universitete 1922-1940 metais. Vilnius 2004 Vaga ss. 328.

Rec.: Selenis Valdas, Lietuvos Istorijos Metraštis. [M. 34]: 2004 [nr] 1 [dr.:] 2005 s. 185-190.

381. VILNIAUS Universitetas Europoje. Praeitis, dabartis, ateitis, $2004 \mathrm{~m}$. rugsd'jo $17 \mathrm{~d}$. International Conference Vilnius University in Europe. Past, present and future. Ed. by Alfredas Bumblauskas. Vilnius 2005 Vilniaus Univ. Leidykla ss. 262, il.

Z treúci: Ávadas s. 5-7; Introduction s. 11-13; Demandt Alexander: Ursprung und Entwicklung der europäischen Universität s. 17-30; Vaitkus Juozas V.: Research at Vilnius University: fundamental and applied sciences s. 73-88; Gudavičius Edvardas: Brief survey of the promulgations in the early act of Lithuania. (Summary) s. 91-93; Grzebień Ludwik: Jezuicki okres w dziejach Uniwersytetu Wileńskiego, jego miejsce wśród uniwersytetów jezuickich i znaczenie w dziejach Rzeczypospolitej Obojga Narodów s. 94-141; Grzebień L.: The jesuit period in the history of Vilnius University, its position among jesuit universities and importance in the history of the Commonwealth of Poland and Lithuania s. 125-141; Ulčinaitë Eugenija: Vilnius University and baroque culture s. 151-160; Ivanov Anatolij J.: Vilenskij Universitet Rossijsko-imperskogo perioda (1803-1832). Vzglâd s vostoka s. 161-171; Ivanov A. J.: Vilnius University of the Russian imperial period (1803-1832). A glance from the East s. 182-192; Alexandrowicz Stanisław: Dziedzictwo dawnego Uniwersytetu Wileńskiego s. 193-203; Bumblauskas A.: Vilnius University: conflicts and dialogues of historical memory s. $243-262$.

382. ZAMOJSKA Dorota: „Ta ludność życzy mieć uniwersytet...” - walka o utworzenie Uniwersytetu Stefana Batorego. Kw. Hist. Nauki i Techn. R. 51: 2006 nr 2 s. 7-46.

1919 r.

\section{Uniwersytet Wrocławski}

383. ARCHITEKTURA budynków uniwersyteckich. Projekty ze zbiorów Muzeum Architektury we Wrocławiu. Pod red. Marii Zwierz. Wrocław 2002 Muzeum Architektury ss. 86, nlb. 2, tabl. 1, il.

Treść: Ilkosz Jerzy, Zwierz M.: Wprowadzenie s. 7-9; Kulak Teresa: Zespół budynków Uniwersytetu Wrocławskiego s. 17-22; Żerelik Rościsław: Pierwszy niezrealizowany projekt Domu Studenckiego autorstwa 
Maxa Berga z 1910 roku s. 23-25; Zwierz M.: Niezrealizowane projekty przebudowy placu Uniwersyteckiego s. 26-30; Wójtowicz Małgorzata, Zwierz M.: Budynki instytutów i seminariów uniwersyteckich s. 31-80.

384. FIEDOR Karol: Habsburgowie a pierwszy uniwersytet nad Odrą. Zbliż. Pol.-Niem. [R. 13]: 2003 z. 1 s. 19-27.

XVI-XIX w.

385. FIEDOR K.: Od Ośrodka Badań Niemcoznawczych do Instytutu Studiów Międzynarodowych. Zbliz. Pol. - Niem. [R. 13]: 2003 z. 3 s. 31-38.

Od 1974 r.

386. GELLES Romuald: Dwa wieki doktoratów honoris causa na Uniwersytecie Wrocławskim (1803-2002). Cz. 1. Zbliż. Pol. - Niem.. [R. 13]: 2003 z. 1 s. 28-35.

Toż. Cz. 2. Tamże z. 2 s. 29-34.

Wołyńska Szkoła Podchorążych Rezerwy Artylerii im. Marcina Kątskiego

387. ZARAKOWSKI Marek: Wołyńska Szkoła Podchorążych Rezerwy Artylerii im. Marcina Kątskiego 1926-1939. [W:] W dolinie Bugu, Styru i Słuczy. Wołyń w najnowszej historii Polski. (Wybrane zagadnienia). Red. nauk. Jarosław Rubacha. Piotrków Trybunalski 2005 s. 185-198.

Wyższe Seminarium Duchowne Archidiecezji Krakowskiej

388. MAGNIFIKAT. 40 lat kapłaństwa. Oprac. i wyd. Andrzej Targosz; graf. Władysław Fijałkowski. Szczecinek 2005 Parafia p.w. św. Rozalii z Palermo ss. 261, nlb. 3, tabl. 8, il.

Ksiega pamiątkowa.

\section{Wyższe Seminarium Duchowne Diecezji Elbląskiej}

389. EWERTOWSKI Stefan: Wyższe Seminarium Duchowne Diecezji Elbląskiej w Elblągu (1992-2002). Studia Elbl. T. 5: 2003 s. 131-143, Zsfg.

\section{BIOGRAFIE}

\section{Zbiory życiorysów}

390. DOKTORZY honoris causa łódzkich uczelni 1945-2005. Red. Elżbieta Paradowska. Lódź 2005 Lódzkie Tow. Nauk. ss. 258.

391. GIZA Jerzy: Sądeccy gimnazjaliści z generalskim wężykiem. Almanach Sq̨dec. R. 15: $2006 \mathrm{nr} 1 / 2$ s. $90-110$.

Od XVII w. 
392. GRĘDZIK-RADZIAK Agnieszka: Polscy nauczyciele z ziem południowo-wschodnich II Rzeczypospolitej - ofiary zbrodni sowieckich w latach 1939-1941 (deportowani, więzieni, zamordowani). Cz. 2. Prz. Hist.-Ośw. R. 49: 2006 nr 3/4 s. 189-254, il.

Cz. 1. Tamże. R. 48: $2005 \mathrm{nr}$ 3/4.

393. GRĘDZIK-RADZIAK A.: Straty osobowe wśród polskich nauczycieli szkół wyższych, powszechnych i średnich $\mathrm{z}$ województwa lwowskiego w czasie II wojny światowej. Rocz. Lwow. 2006 s. 59-75.

Spisy.

394. HAŁABURDA Marek, Szczepaniak Jan: Katalog alumnów seminarium na Stradomiu (1801-1900). Wyd. 2 popr. Kraków 2006 Wydaw. Nauk. PAT ss. 284. (Bibliotheca Collectanea Historica; t. 4).

Instytut Teologiczny Księży Misjonarzy w Krakowie.

Wyd. 1 pt.: Katalog alumnów seminarium stradomskiego (1801-1900). Kraków 2003.

395. [KADRA naukowa Politechniki Łódzkiej]. Zesz. Hist. Politech. Łódz. Z. 1: 2002 s. 9-107.

Treść: Kroh Jerzy: [Profesor Bohdan Stefanowski (1883-1976). Twórca i pierwszy rektor Politechniki Łódzkiej] s. 9-16; Leplawy Mirosław T.: Osman Achmatowicz (1899-1988), profesor, kierownik Katedry Chemii Organicznej (1945-1953), wspóttwórca, prorektor (1945-1948 i 1952/53) i drugi rektor (1948-1952) Politechniki Lódzkiej s. 17-32; Karniewicz Jan: Profesor Andrzej Sołtan [1897-1959] - zarys działalności s. 33-40; Tadeusiewicz Michał, Morawska Hanna: Wspomnienie o profesorze Bolesławie Konorskim [1892-1986] s. 41-51; Kroh J.: Wspomnienie o profesor Alicji Dorabialskiej [1897-1975] s. 53-58; Szczepaniak Cezary: Wspomnienie o profesorze Jerzym Wernerze [1909-1977] s. 59-63; Zakrzewski Kazimierz: Profesor zwyczajny maszyn elektrycznych Eugeniusz Jezierski, doktor honoris causa Politechniki Lódzkiej (1902-1990) s. 65-71; Boguslawska Krystyna: Edward Józefowicz (1900-1975), profesor chemii nieorganicznej, współtwórca Wydziału Chemicznego Politechniki Łódzkiej s. 73-77; Strumiłło Czesław: Fragmenty wspomnień o profesorze Mieczysławie Serwińskim [1918-1999] s. 79-87; Wasilewski Przemysław: Wspomnienie o profesorze Michale Skarbińskim, dr h.c. Politechniki Łódzkiej [1903-1997] s. 89-95; Dobrzycki Jan: Profesor Stanisław Zagrodzki (1906-1980) s. 97-101; Koszmider Andrzej, Piotrowski Zbigniew: Wspomnienie o profesorze Walentym Starczakowie [1906-1999] s. 103-107.

396. KAPUŚNIAK Artur, Szczepaniak Jan: Katalog alumnów krakowskiego Seminarium Duchownego (1901-1938). Wyd. 2 popr. Kraków 2006 Wydaw. Nauk. PAT ss. 280. ( Bibliotheca Collectanea Historica; t. 5).

Wyd. 1. 2004.

397. KATALOG alumnów seminarium papieskiego w Wilnie 1582-1798. Cz. 2: Katalog alumnów 501-1037, Indeks nazwisk alumnów. Oprac. Henryk Litwin. Prz. Wsch. T. 9: 2004 z. 2 s. $301-377$.

Cz. 1. Tamże. T. 8: 2002 z. 4.

398. POCZET rektorów Szkoły Głównej Handlowej w Warszawie. Red. nauk. Janusz Kaliński. Warszawa 2006 SGH. Oficyna Wydawnicza ss. 150, nlb. 1, il.

$\mathrm{XX}-\mathrm{XXI} \mathbf{w}$.

399. PRACOWNICY nauki i dydaktyki Uniwersytetu Mikołaja Kopernika 1945-2004. Materiały do biografii. Oprac. Henryka Duczkowska-Moraczewska [i in.]; koncepcja i red. Sławomir Kalembka. Toruń 2006 Wydaw. Uniw. Mikołaja Kopernika ss. 799, tabl. 4, il.

400. SADOWSKI Wojciech: Poczet wychowawców i nauczycieli Małego Seminarium Duchownego w Gorzowie. Nadwarc. Rocz. Hist.-Archiw. Nr 13: 2006 s. 195-203. 
401. SŁOWNIK biograficzny profesorów Uniwersytetu Rzeszowskiego 2001-2006. Pod red. Włodzimierza Bonusiaka. Rzeszów 2006 Wydaw. Uniw. Rzeszowskiego ss. 168, il.

402. SZCZEPANIAK Jan: Katalog alumnów seminarium stradomskiego (1732-1800). Wyd. 2 popr. Kraków 2006 Wydaw. Nauk. PAT ss. 196. (Bibliotheca Collectanea Historica; t. 3).

Instytut Teologiczny Księży Misjonarzy w Krakowie.

Wyd. 1. 2003.

\title{
2. Poszczególne osoby
}

\author{
Adamski Walerian
}

403. PONCZEK Mirosław: O księdzu Walerianie Adamskim - teoretyku wychowania fizycznego w Polsce (1885-1965). Materiał uzupełniający do ćwiczeń i seminariów z historii kultury fizycznej oraz teorii wychowania fizycznego. Poznań 2006 Druk. i Księg. św. Wojciecha ss. 101, nlb. 3, il., sum.

\section{Angiolini Giuseppe (Józef)}

404. DAROWSKI Roman: Giuseppe Angiolini SJ (1747-1814), profesor filozofii w Akademii Połockiej. Forum Philosophicum. T. 11: 2006 s. 223-247, sum.

W aneksie: Angiolini Józef: Institutiones philosophicae. De ente ejusque essentia ac existentia. Wykłady filozoficzne. $\mathrm{O}$ bycie oraz jego istocie $\mathrm{i}$ istnieniu.

\section{Bandura Ludwik}

405. CHMIELEWSKI Witold: Ludwik Bandura (1904-1984). Prz. Hist.-Ośw. R. 49: 2006 nr 1/2 s. $157-160$.

\section{Barczewski Walenty}

406. KASPAREK Danuta: Działalność pedagogiczna księdza Walentego Barczewskiego. [W:] Ad fontes. Studia ofiarowane księdzu profesorowi Alojzemu Szorcowi w siedemdziesięciolecie urodzin. Pod red. Zoi Jaroszewicz-Pieresławcew i Ireny Makarczyk. Olsztyn 2006 s. 145-154.

\section{Bryjak Franciszek}

407. CHYL Olga: Franciszek Bryjak [1904-1958] - nauczyciel o duszy górala. Almanach Kẹcki. [T.] 10: 2006 s. 183-186. 


\section{Bulanda Stefan}

408. FOKSZAN Lucjan: Płk pil. dr Stefan Bulanda dyrektor Zespołu Szkół Akademickich „Lotnika” - IV Liceum Ogólnokształcącego i Gimnazjum nr 10 w Zielonej Górze. Zarys biografii 1939-2004. Zielona Góra 2004 Wydaw. „Maxim” Lucjan Fokszan ss. 104, il.

\section{Doliwa-Dobrowolska Małgorzata}

409. SZCZĘSNY Mikołaj: Małgorzata Doliwa-Dobrowolska [1908-1990]. Portret nauczycielki gry na fortepianie. Stargardia. T. 4: 2004 [dr.:] 2006 s. 259-277, Zsfg.

\section{Falski Marian}

410. KUCZYŃSKI Antoni: „Życie i dzieło prof. Mariana Falskiego" - konferencja naukowa w Kuźnicy Grabowskiej. Rocz. Kalis. T. 32: 2006 s. 295-301.

2-3 IX 2005 r.

\section{Feldman Józef}

411. BILIŃSKI Piotr: Droga kariery akademickiej Józefa Feldmana [1899-1946] na Uniwersytecie Jagiellońskim. Kw. Hist. Nauki i Techn. R. 51: 2006 nr 3/4 s. 39-56, sum.

\section{Fortuna Marian}

412. PACIOREK Anna: Doktor Marian Fortuna (1950-2006). Rocz. Lud. Tow. Nauk.-Kult. Oddz. w Krakowie. Nr 7: 2006 s. 300-302.

\section{Gębik Władysław}

413. CH£OSTA Jan: Warmiak z Podhala. Władysław Gębik [1900-1986] pedagog, folklorysta, literat. Olsztyn 2006 Tomasz Śrutkowski Edytor „Wers” ss. 202, nlb. 2, il.

\section{Hollack Emil}

414. HOFFMANN Mirosław: Emil Hollack [1860-1924] - nauczyciel, historyk i badacz pradziejów ziemi mrągowskiej. W 80. rocznicę śmierci. Mrąg. Studia Hum. T. 6/7: 2004/2005 [dr.:] 2006 s. 17-27, Zsfg. 


\section{Horwath Edward}

415. SZMYD Kazimierz: Edward Horwath (1881-1962). Z biografii nauczyciela, moralisty i świadka dziejów Galicji. Zesz. Nauk. Uniw. Rzesz. Nr 24: Ser. Pedagog.: Pedagogika i Psychologia. [Z.] 2: 2004 s. 101-117, streszcz., sum.

\section{Jackowski Antoni}

416. MILLER Jerzy: Antoni Jackowski (1923-2005). Prz. Hist.-Ośw. R. 49: 2006 nr 3/4 s. $265-267$.

\section{Jankowski Jan}

417. ADAMCZEWSKI Piotr S.: Jan Jankowski (1910-1993) nauczyciel, kierownik szkoły w Rynarzewie, harcerz, żołnierz „Szarych Szeregów”, publicysta. [W:] Duch i czas. Materiały do dziejów historii i kultury Szubina i okolicy. [T.] 2. Red. i oprac. graf. Kamila Czechowska, Mirosław Rzeszowski. Szubin 2006 s. 57-59.

\section{Jenke Anna}

418. LIPIAN Bernadeta: Pedagog z charakterem. Rzecz o Annie Jenke [1921-1976]. Dokument historyczno-wychowawczy. Rzeszów-Jarosław 2006 Poligrafia Wyższego Seminarium Duchownego; nakł. Tow. Przyj. Anny Jenke ss. 140, nlb. 2, il.

419. O ANNIE Jenke [1921-1976] i jej programie wychowawczym. Wychowywać z miłości i poczucia odpowiedzialności. Red. Bernadeta Lipian. Rzeszów 2006 Poligrafia Wyższego Seminarium Duchownego ss. 39, nlb. 1, il.

\section{Kamiński Aleksander}

420. PÓŁTURZYCKI Józef: Aleksander Kamiński. Warszawa-Radom 2006 Wydaw. Inst. Technologii Eksploatacji - Państ. Inst. Badawczego ss. 352, tabl. 20, il.

\section{Komarnicki Zbigniew}

421. KASICZ Kazimierz: Zbigniew Komarnicki [1930-2001] - nauczyciel i działacz społeczny. Ziemia Prudn. 2003 s. 168-169. 


\section{Korczak Janusz}

422. GOLDYS Olimpia, Szczepaniak Elke: Wege zum Kind. Zur Bedeutung von Musik in der Pädagogik von Janusz Korczak [1878-1942]. Korczak-Bulletin. Bd. 14: 2005 H. 2 s. 30-41, il.

423. PAMIĘCI Janusza Korczaka [1878?-1942]. Materiały z sesji popularnonaukowej, Muzeum Narodowe Pałac Biskupów Krakowskich w Kielcach 1 czerwca 2005. Pod red. Jadwigi Chmielewskiej i Doroty [Anny] Mętrak. Kielce 2006 Wydaw. Agencja JP ss. 106, tabl. 7, il. Gimnazjum nr 3 im. Janusza Korczaka w Kielcach.

Z treści: Urbański Krzysztof: Społeczność żydowska w Polsce s. 11-21; Matyjas Bożena: Koncepcja i system wychowania Janusza Korczaka s. 23-30; Katny Marek: Twórczość Janusza Korczaka dla młodych odbiorców s. 47-65; Braniewski Marcin: Janusz Korczak czyli jak być człowiekiem w nieludzkich czasach s. 67-80; Mętrak D. A.: Janusz Korczak w sztuce s. 81-90.

\section{Kurpisz Kazimierz}

424. POLAŃSKA Mariola, Walter Hanna: Dr Kazimierz Kurpisz (1901-1983) - wieloletni dyrektor Zakładu Poprawczego w Szubinie. [W:] Duch i czas. Materiały do dziejów historii i kultury Szubina i okolicy. [T.] 2. Red. i oprac. graf. Kamila Czechowska, Mirosław Rzeszowski. Szubin 2006 s. 62-64.

\section{Kuznowicz Mieczysław}

425. MÓ£KA Janusz: Ks. Mieczysław Kuznowicz SJ [1874-1945] - wychowawca młodzieży. Kraków 2006 Wydaw. WAM ss. 194, nlb. 2, tabl. 16, il.

\section{Maj Jadwiga}

426. CZAS uchwycony w słowach. Tadeusz Garczyński i inni o Jadwidze Maj. Pod red. Joanny Marszałek-Kawy, Joanny Jastrzębskiej. Toruń 2006 Adam Marszałek ss. 159, il.

\section{Majorek Czesław}

427. SZMYD Kazimierz: Prof. dr hab. Czesław Majorek (1938-2002). Sylwetka uczonego i nauczyciela. Zesz. Nauk. Uniw. Rzesz. Nr 24: Ser. Pedagog.: Pedagogika i Psychologia. [Z.] 2: 2004 s. 213-221.

\section{Marczyńska Zofia}

428. PRZYBYŁKO Kazimierz: Działalność pedagogiczna, bibliotekarska i społeczna Zofii Marczyńskiej (1897-1989). Bibliotekarz Lubelski. R. 49: 2006 s. 127-130. 


\section{Markiewicz Bronisław}

429. PAWLUK-SKRZYPEK Agnieszka: System pedagogiczny ks. Bronisława Markiewicza [1842-1912] jako jedna z możliwości wychowywania dzieci i młodzieży w placówkach opiekuńczych. Lub. Rocz. Pedag. T. 25: 2005 s. 193-207.

\section{Mianowski Józef}

430. ZASZTOWT Leszek: Józef Mianowski [1804-1879] w humańskiej szkole bazylianów. Prz. Wsch. T. 9: 2004 z. 1 s. 131-147.

\section{Michna Wojciech}

431. LORENS Beata: Ksiądz Wojciech Michna [1820-1893] z Chłopic - prekursor pracy społeczno-oświatowej na wsi galicyjskiej w XIX wieku. Rocz. Stow. Miłośn. Jarosławia. T. 16: 2005 [dr.:] 2006 s. 169-193.

\section{Paliński Piotr}

432. BAAR Maria: Piotr Paliński [1853-1950]. Nauczyciel, redaktor, pisarz. Poznań 2006 Media Expo ss. 136, tabl. 3, il. (Niezapomniani, Nadzwyczajni, Niepospolici).

\section{Pawłowski Stanisław}

433. PROF. dr phil. Stanisław Pawłowski [1882-1940] dębowiczanin, geograf i nauczyciel, profesor i rektor Uniwersytetu Poznańskiego. Zebrał i oprac. Zbigniew Stanisław Pawłowski. Poznań 2006 Kontekst ss. 80, il.

\section{Pestalozzi Johann Heinrich}

434. JOHAN [!] Heinrich Pestalozzi [1746-1827] i jego olescy uczniowie. Oprac. red. Norbert Hober. Olesno-Gliwice 2004 Starostwo Pow.; Dom Współpracy Pol.-Niem. ss. 43, nlb. 1, il.

M.in. Józef Lompa (1797-1863).

\section{Piramowicz Grzegorz}

435. GAWLIK Stanisław: Grzegorz Piramowicz [1735-1801] - idee, słowa, czyny. Opolski 2006 Uniw. Opolski ss. 164, il. 


\section{Pirożyński Marian}

436. PELCZARSKI Kazimierz: Działalność wychowawcza o. Mariana Pirożyńskiego (1899-1964). Lublin 2006 TN KUL ss. 321, nbl. 3, il., sum. Tow. Nauk. KUL Jana Pawła II. (Źródła i Monografie; 304).

\section{Poznański Karol}

437. MARKIEWICZOWA Hanna: Profesor Karol Poznański [ur. 1931] - życie i działalność naukowa. Prz. Hist.-Ośw. R. 49: 2006 nr 3/4 s. 259-263.

\section{Smołalski Antoni}

438. MIELCZAREK Ferdynand: Profesor Antoni Smołalski [ur. 1928] - pedagog, historyk wychowania, pedeutolog, teoretyk organizacji szkolnictwa. Prz. Hist.-Ośw. R. 49: $2006 \mathrm{nr}$ 3/4 s. $255-257$.

\section{Staszic Stanisław}

439. KUCHARSKA Czesława: Myśl edukacyjna Stanisława Staszica. [W:] Stanisław Staszic i jego epoka. Red. nauk. Czesława Kucharska, Zbigniew Popławski. Piła 2006 s. 95-103.

\section{Strużyński Romuald}

440. KRAJEWSKI Mirosław: Romuald Strużyński - kierownik oborskiej szkoły, ofiara zbrodni hitlerowskich na ziemi dobrzyńskiej (1907-1939). Ziemia Dobrz. R. 10: 2006 s. 260-265.

\section{Szlonzak Jan}

441. KALISZ Jan: Jan Szlonzak 1907-1991. Hrubieszów 2005 Wydaw. Polihymnia ss. 127, il. (Biblioteka Towarzystwa Regionalnego Hrubieszowskiego; t. 41).

\section{Szopa Jan}

442. SIKORA Krystyna: Jan Szopa (1940-2005). Rocz. Sqdec. T. 34: 2006 s. 477-481. Nauczyciel i dyrektor LO w Nowym Sączu, docent AWF w Krakowie. 


\section{Szuman Stefan}

443. BARNAŚ-BARAN Ewa: Stefan Szuman [1889-1972] w poszukiwaniu uniwersalnych cech osobowości nauczyciela wychowawcy. Zesz. Nauk. Uniw. Rzesz. Nr 24: Ser. Pedagog.: Pedagogika i Psychologia. [Z.] 2: 2004 s. 118-135, streszcz., sum.

\section{Szuman Wanda}

444. WAŁĘGA Agnieszka: Życie i działalność Wandy Szuman (1890-1994). Toruń 2005 Mado ss. 203, il.

\section{Świerzowicz Michał}

445. CHRZELEST Małgorzata: Michał Świerzowicz (1889-1954). Nauczyciel, bibliotekarz, społecznik. Zesz. Sandom. R. 12: $2005 \mathrm{nr}$ 20/21 s. 87-97.

\section{Twaróg Franciszek}

446. GRYCZYŃSKI Adam: Franciszek Twaróg [1891-1968]. Nauczyciel z Luboczy. Kraków 2006 Nowohuckie Centrum Kultury ss. nlb. 28, i1.

\section{Woroniecki Jacek}

447. BŁESZYŃSKA Zofia: O. Jacek Woroniecki 1878-1949. Dominikanin, wychowawca, patriota. Oprac. red. Aneta Piątkowska. Lublin 2006 Fund. Servire Veritati. Inst. Edukacji Nar. ss. 272.

\section{DZIEJE OŚWIATY POZASZKOLNEJ}

\section{Oświata dorosłych}

448. UNIWERSYTET ludzi dojrzałych. Dziesięciolecie (1993-2003). Oprac. Krystyna Kamińska. Gorzów Wielkopolski 2003 Wydaw. Artystyczno Graficzne „Arsenał”; na zlec. Stow. Uniw. Trzeciego Wieku ss. 80, il.

Uniwersytet Trzeciego Wieku w Gorzowie Wielkopolskim.

449. WALBURG Mirosława: Zagadnienia oświaty dorosłych w Kutnowskiem w dwudziestoleciu międzywojennym. Kutn. Zesz. Region. T. 10: 2006 s. 349-360. 


\section{Biblioteki}

450. DARA Urszula, Słowik Józef: Z dziejów Młodzieżowego Domu Kultury w Nowym Sączu. Rocz. Sqdec. T. 34: 2006 s. 297-307.

W 1. 1951-2005.

451. DZIENIAKOWSKA Jolanta: Kuratoryjna biblioteka pedagogiczna w Wilnie (1924-1939). Geneza. Organizacja. Dzieje Najn. R. 38: 2006 [nr] 1 s. 47-63, sum.

452. DZIENIAKOWSKA J.: Państwowa Centralna Biblioteka Pedagogiczna Kuratorium Okręgu Szkolnego Lwowskiego we Lwowie (1926-1939). [W:] Kraków - Lwów. Książki, czasopisma, biblioteki. T. 8. Pod red. Haliny Kosętki. Kraków 2006 s. 287-297.

453. DZIENIAKOWSKA J.: Państwowa Centralna Biblioteka Pedagogiczna we Lwowie w świetle publikacji "Dziennika Urzędowego Kuratorium Okręgu Szkolnego Lwowskiego" (1926-1939). Zapiski L'vivs'kod' naukovod' béblěoteki ếm. V. Stefanika. Vip. 13: 2005 s. 186-197, sum., rez.

454. DZIENIAKOWSKA J.: Źródła archiwalne do dziejów bibliotek dla nauczycieli Drugiej Rzeczypospolitej 1918-1939. Rocz. Bibliot. R. 50: 2006 s. 195-211, sum.

455. HAPTAŚ Krystyna Maria: Książki z księgozbioru gimnazjalnego w zbiorach biblioteki Muzeum Regionalnego w Mielcu. Rocz. Miel. T. 7/8: 2004/2005 [dr.:] 2006 s. 341-346.

W aneksie: Wykaz 24 książek z XIX i XX w.

456. KULKA Bronisława: Lwowskie i krakowskie biblioteki szkół średnich w autonomicznej Galicji (1868-1918). [W:] Kraków - Lwów. Książki, czasopisma, biblioteki. T. 8. Pod red. Haliny Kosętki. Kraków 2006 s. 298-315.

457. LEWIŃSKA Jadwiga: Najstarsze podręczniki z zakresu prawa karnego w Bibliotece Wydziału Prawa, Administracji i Ekonomii Uniwersytetu Wrocławskiego. Acta Univ. Wr. No 2887: Prawo. [T.] 298: Studia historycznoprawne: 2006 s. 437-465, Zsfg.

Od początku XIX w.

458. MADERSKA Jolanta: Monografia Biblioteki Pedagogicznej w Lęborku. Biul. Hist. [Lęborskie Bractwo Hist.]. Nr 29: 2006 s. 58-63.

Od 1951 r.

459. OLBERT Joanna: Biblioteki Gimnazjum Polskiego Macierzy Szkolnej w Wolnym Mieście Gdańsku. [W:] Z dziejów kultury Pomorza XVIII-XX wieku. Materiały z seminarium na Uniwersytecie Gdańskim z 25 kwietnia 2005 roku. T. 3. Pod red. Józefa Borzyszkowskiego, Cezarego Obracht-Prondzyńskiego. Poznań 2006 s. 229-269.

460. PARYSZ Janina, Drosdzol Jolanta: $Z$ dziejów bibliotek nauczycielskich w Chorzowie. Chorzów-Świętochłowice 2006 Pedagog. Bibl. Woj. im. J. Lompy w Katowicach. Filia; przy wspótpr. Agencji Wydawniczo-Reklamowej ss. 116, tabl. 4, il.

XIX-XXI w.

461. REIZES-DZIEDUSZYCKI Jerzy: Książka i biblioteka w działalności polskich towarzystw naukowych młodzieży akademickiej we Lwowie w okresie autonomii galicyjskiej. Katowice 2005 Wydaw. Uniw. Śląskiego ss. 235, nlb. 1, sum., Zsfg. (Prace Naukowe Uniwersytetu Śląskiego w Katowicach; $\mathrm{nr}$ 2326).

XIX-XX w. 
462. [SZEŚĆDZIESIĄT] 60 lat Pedagogicznej Biblioteki Wojewódzkiej w Rzeszowie 1945-2005. Pod red. Teresy Gębarowskiej i Marty Jarosiewicz. Rzeszów 2005 Podkarpackie Centrum Edukacji Nauczycieli ss. 110, nlb. 2, il.

463. WARMIŃSKO-MAZURSKA Biblioteka Pedagogiczna im. Profesora Tadeusza Kotarbińskiego w Olsztynie 1946-2006. Oprac. zespół Zbigniew Ślesiński [i in.]. Olsztyn 2006 Warmińsko-Mazurska Bibl. Pedagog. im. Profesora Tadeusza Kotarbińskiego ss. 70, tabl. 2.

\section{DZIEJE RUCHU NAUCZYCIELSKIEGO}

\section{Opracowania ogólne}

464. DĄBROWA Marian: Związek Nauczycielstwa Polskiego w Uniwersytecie Jagiellońskim. Z okazji 60-lecia. Kraków 2005 ZNP w UJ ss. 73.

Rec.: Wiaderek Wioletta, Prz. Hist.-Ośw. R. 49: $2006 \mathrm{nr}$ 1/2 s. 170-172.

465. FLASZ Grażyna: 100 lat Związku Nauczycielstwa Polskiego. Almanach Kęcki. [T.] 10: 2006 s. $190-195$.

W Kętach od 1946 r.

466. GRZEŚ Bolesław: Służyć edukacji, nauce, nauczycielstwu i idei związkowej (refleksje jubileuszowe). Prz. Hist.-Ośw. R. 49: 2006 nr 1/2 s. 5-12.

100-lecie istnienia i działalności Związku Nauczycielstwa Polskiego.

467. MIKITIUK Renata: Reaktywowanie struktur Związku Nauczycielstwa Polskiego na Lubelszczyźnie oraz jego działalność w celu poprawy sytuacji ekonomicznej nauczycieli (lata 1944-1945). Krak. Studia Małop. Nr 10: 2006 s. 237-252, sum.

\section{Pamiętniki nauczycieli}

468. DZIKIEWICZ Władysław: Wspomnienia nauczyciela z Żyrardowa (1862-1940). Społecznik i patriota z przełomu XIX i XX wieku. Oprac. Leszek Wojciech Dzikiewicz, Władysław Zygmunt Traczyk. Tuchów 2006 Mała Poligrafia Redemptorystów ss. 186, tabl. 4, il.

469. GAŹDZICKI Jan: Ze Szczekocin nad Berezynę. Oprac. Teresa Gaździcka i Jerzy Gaździcki. Warszawa 2006 Wydaw. Wieś Jutra ss. 103, nlb. 1, il. Tow. Kult. im. Tadeusza Kościuszki w Szczekocinach.

Wspomnienia nauczyciela (1900-1983), syna rolnika i szewca ze Szczekocin, obejmujące dzieciństwo, naukę w szkole ludowej i progimnazjum w rodzinnej miejscowości, służbę w Legionach oraz walki na froncie ukraińskim.

470. HALLER Anna: Nogi bolą, ale uczę... Wybór wspomnień. Wybrał, przygot. do dr. i niezbędnymi koment., wstępem oraz posłowiem opatrzył Krzysztof Rajewicz. Kożuchów-Głogów 2006 Netprojekt Artur Królak ss. 163, nlb. 6, il.

Pamiętnik nauczycielki żyjącej w 1. 1876-1969. 
471. HORBOWY Genowefa: Żaneta. Sł. wstępne Sławomir Horbowy. Opole 2006 Nakł. własnym. aut.; Wydaw. Inst. Śląski ss. 89, il.

Wspomnienia z wojny spędzonej na Wileńszczyźnie, powojennych studiów z filologii rosyjskiej w Krakowie i pracy nauczycielskiej.

472. JĘDRAŚ Stanisław: Wspomnienia z pracy w Państwowym Liceum Pedagogicznym im. Jana Amosa Komeńskiego w Lesznie. Leszno 2006 Starostwo Pow. ss. 48, il.

Wspomnienia nauczyciela.

473. KNYBA Jerzy: Wspomnienia wpisane w historię Małej Ojczyzny - Kaszub. Pod red. Antoniego Starka. Toruń 2006 Stow. Oświatowców Pol. Oddz. ss. 148, il.

Wspomnienia z dzieciństwa i młodości spędzonych w czasie wojny w ziemi puckiej, powojennych studiów historycznych na UJ, pracy nauczyciela historii i łaciny oraz dyrektora w Liceum Ogólnokształcącym w Kościerzynie.

474. MOJA praca nauczycielska - wczoraj, dziś i jutro. Prace nagrodzone i wyróżnione w konkursie na pamiętniki nauczycieli. T. 1-2. Red. Krystyna Zbytniewska. Warszawa-Kielce 2006 IGS SGH; Wydaw. Pedag. ZNP ss. 372; 392. ZNP, Inst. Gospodarstwa Społ. SGH w Warszawie.

475. OGIEGLO Stanisława: Mój wkład pracy w przyszłość edukacji na Górnym Śląsku. Autobiografia. Pod red. Ireny Norskiej-Borówki i Marii E. Kempy. Bielsko-Biała 2006 alfa-Medica Press Wydaw. Medyczne ss. 200, il., sum.

Wydawnictwo jubileuszowe w 23 rocznicę smierci autorki.

476. OKOŃ Wincenty: Samo życie osiemdziesięciolatka. $\mathrm{Z}$ autobiografią naukową autora. Warszawa 2005 Wydaw. Akdemickie „Żak" ss. 265, tabl. 10.

Pamiętnik profesora pedagogiki Uniwersytetu Warszawskiego ur. w 1914 r.

Rec.: Kwiatkowska Henryka: Oficjalność i codzienność na przykładzie książki Profesora Wincentego Okonia: Samo życie osiemdziesięciolatka z autobiografią naukową autora. Rocz. Pedagog. T. 29: 2006 s. 175-180.

477. PIERWSZE lata na Ziemiach Zachodnich. Podał do dr. Maciej Zalewski. Wrocław 2005 Oficyna Wydawnicza Atut - Wrocławskie Wydaw. Oświatowe ss. 303, il. Tow. Miłośn. Lwowa i Kresów Południowo-Wschodnich.

Antologia wspomnień nauczycieli akademickich.

478. ROKICKA Anna: Dziennik nauczycielki z Kazachstanu. My, Sybiracy. Nr 17: 2006 s. $219-231$.

Zapiski z pobytu w Kazachstanie 1, 90. XX w.

\section{ORGANIZACJE MLODZIEŻOWE}

479. BARTKOWIAK Przemysław: Powstanie i rozwój harcerstwa na terenie Babimojszczyzny w okresie międzywojennym. [W:] Polacy, Niemcy, Pogranicze. Studia historyczne. Red. nauk. Grażyna Wyder, Tomasz Nodzyński. Zielona Góra 2006 s. 209-225.

480. BRODACKI Jakub: „Prołuż” Akademicki Związek Przyjaciół Łużyc. Historia wewnętrzna organizacji (1945-1949). Warszawa 2006 Pol. Grupa Marketingowa ss. 120, nlb. 1, il. (Biblioteka Nauki i Kultury Polskiej).

Rec.: Borzyszkowski Józef, Rocz. Gdań. T. 66: 2006 s. 200-201. 
481. BUKOWSKI Jerzy: Harcerskie „knucie” pod Kopcem Józefa Piłsudskiego. Sowiniec. Nr 28: 2006 s. 99-101.

Ogniska harcerskie organizowane pod Kopcem w 1. 80. XX w.

482. CHRABAุSZCZ Jerzy: Harcerze gorszego Boga. Związek Harcerstwa Polskiego w okresie transformacji ustrojowej państwa lat 1989-1990. [Wyd. 2]. Toruń 2006 Adam Marszałek ss. 513, il.

Rec.: Kunowski Jędrzej, Rocz. Hist. Harcerstwa. [T.] 2: 2006 s. 91-94; Chodurski Andrzej: Opinia o wydruku komputerowym opracowania Jerzego Chrabąszcza... Tamże s. 95-97.

Wyd. 1. 2005.

483. DĘBSKI Franciszek: Krajowa Rada Zuchmistrzów, Styczeń 1988 - październik 1990. Rocz. Hist. Harcerstwa. [T.] 2: 2006 s. 107-110.

Wspomnienia.

484. DĘBSKI Franciszek: Miasteczko harcerskie Podgrodzie. Wspomnienia z lat 1954 i 1955. Rocz. Hist. Harcerstwa. [T.] 1: 2005 s. 120-125.

Osada k. Nowego Warpna nad Zalewem Szczecińskim.

485. [DOKUMENTY do dziejów harcerstwa polskiego z lat 1956-1985]. Rocz. Hist. Harcerstwa. [T.] 1: 2005 s. $142-149$.

486. [DOKUMENTY do dziejów harcerstwa polskiego $\mathrm{z}$ lat 1956-1995]. Rocz. Hist. Harcerstwa. [T.] 2: 2006 s. 139-159.

487. FAŁKOWSKI Wojciech: „Czarna Jedynka”. Niezależna drużyna harcerska w PRL. Biul. IPN. $2006 \mathrm{nr} 8 / 9$ s. $121-126$.

488. GLIWKA Grażyna: Rozłam w szeregach ZHP po 1980 roku. Rocz. Hist. Harcerstwa. [T.] 1: 2005 s. $48-61$.

PRL i III RP.

489. GLOWACKA-SOBIECH Edyta: Ruch harcerski w Polsce w latach 1944-1989. Stan badań i postulaty badawcze. Prz. Hist.-Ośw. R. 49: 2006 nr 1/2 s. 129-138.

490. HARCERSKA watra nad Pasłęką. Szkice i źródła do historii Hufca Związku Harcerstwa Polskiego im. Mikołaja Kopernika w Braniewie 1946-2005. Red. i uzup. Jerzy Chrabąszcz. Olsztyn 2006 Olsztyńska Szkoła Wyższa im. Józefa Rusieckiego ss. 250, il.

491. HARCERSTWO na Pomorzu i Kujawach w latach 1945-1950 w świetle dokumentów Wojewódzkiego Urzędu Bezpieczeństwa Publicznego w Bydgoszczy. [Wyd.] Ludwik Stanisław Szuba. Bydgoszcz 2006 Wydaw. KPSW ss. 274, nlb. 2, il., Zsfg.

492. JANKIEWICZ Patryk: Wierni Bogu i Polsce. 15 lat Szczepu Harcerskiego „Górskie Bractwo". Krosno 2005 Szczep Harcerski „Górskie Bractwo" ss. 200, il.

493. KAMIŃSKI Aleksander: Wielka gra. Oprac. Andrzej Krzysztof Kunert; przedm. Stanisław Broniewski „Orsza”. Warszawa 2006 Rytm ss. 331, nlb. 1, tabl. 24.

Harcerstwo w 1. 1939-1945.

494. KIEWICZ Adam: Harcerstwo w Polsce Ludowej. Wrocław 2003 B.w. ss. 553, tabl. 26, il.

Rec.: Koźniewski Kazimierz: Harcerstwo prawdziwie uwikłane. Rocz. Hist. Harcerstwa. [T.] 1: 2005 s. $102-115$.

495. KIJOWSKI Maciej: Marian Spychalski i Henryk Jabłoński. Przewodniczący Rady Państwa na czele Rady Głównej Przyjaciół Harcerstwa. Rocz. Hist. Harcerstwa. [T.] 2: 2006 s. 66-87. 
496. KOCENT Mieczysław: O początkach skautingu - harcerstwa polskiego w Wałczu. Rocz. Hist. Harcerstwa. [T.] 1: 2005 s. 12-19.

Od 1912 r.

497. KÖHLER Piotr: Koło Przyrodników Studentów Uniwersytetu Jagiellońskiego. 130 lat tradycji (1873-2003). Kraków 2006 Wydaw. UJ ss. 210, tabl. 16, il., sum.

498. KONCET Mieczysław: Harcerstwo Zachodniopomorskie spod znaku „Rodła”. Rocz. Hist. Harcerstwa. [T.] 2: 2006 s. 11-24.

Lata 1926-1939.

499. KORPAK Janusz: Zarys historii Męskiego Hufca w Nowym Sączu w latach 1945-1949. Rocz. Hist. Harcerstwa. [T.] 1: 2005 s. 20-37.

500. KOŚCIELNY Tomasz: „Historia uczy żyć” - 10 lat 15-tej Szczecińskiej Drużyny Wędrowników ZHR „Arbor" [1996-2006]. [W:] Salezjanie w Szczecinie. 60 lat pracy duchownych synów świętego Jana Bosko w Grodzie Gryfa. Materiały z sesji historycznej przeprowadzonej w Szkołach Salezjańskich przy ul. Ku Słońcu 124 w Szczecinie z okazji 88 rocznicy odzyskania niepodległości w dniu 13.11.2006 r. Pod red. Jacka Brakowskiego. Szczecin 2006 s. 111-116.

501. KOZŁOWSKA Małgorzata: Informacja o zasobie archiwalno-biliotecznym kolekcji harcerskiej Muzeum Historycznego Miasta Krakowa. Krzysztofory. [T.] 24: 2006 s. 161-164.

502. KUKLA Wiesław, Miszczuk Marian: Dzieje harcerstwa na obczyźnie 1912-2006. Zarys problematyki. Warszawa 2006 Tomiko ss. 137, nlb. 1. Światowa Rada Badań nad Polonią. Kom. ds. Dziejów Harcerstwa na Obczyźnie. (Dzieje Harcerstwa na Uchodźstwie i Poza Krajem; t. 1).

503. KWIEK Julian: Dylematy polskiego harcerstwa w latach 1945-1950. Rocz. Hist. Harcerstwa. [T.] 2: 2006 s. 33-42.

504. LEŚNIOWSKI Henryk: Powstanie i działalność Warmińsko-Mazurskiej Chorągwi ZHP (1945-1950). Rocz. Hist. Harcerstwa. [T.] 1: 2005 s. 38-46.

505. MIŁOBĘDZKI Paweł: Harcerze w okupowanym Krakowie 1939-1945. Kraków 2005 Kom. Hist. Krakowskiej Chorągwi ZHP ss. 86, nlb. 2, tabl. 16, il.

506. MURANYI Roman: Problemy Organizacji Harcerskiej - $(\mathrm{OH})$ - dziecięcego członu Związku Młodzieży Polskiej w latach 1950-1956. Rocz. Hist. Harcerstwa. [T.] 2: 2006 s. 43-49.

507. NABZDYK Zygmunt: Początki harcerstwa na ziemi prudnickiej. Ziemia Prudn. 2002 s. $67-71$.

Od początku 1. 30. XX w. do 1949 r.

508. OCALMY od zapomnienia. Wspomnienia działaczy ZMW, nadesłane na apel inicjatorów uczczenia 50 rocznicy powstania w 1957 roku organizacji: Zdzisława Dorosińskiego, Jana Mazura oraz Antoniego Baryły, Marka Kwiecińskiego i Jana Lyska. Oprac. red. Stanisław Durlej. Kielce 2006 Lud. Tow. Nauk.-Kult. Oddz. ss. 265, il. Zw. Młodzieży Wiejskiej.

509. ODYNIEC Wacław: Strzępy wspomnień. Studenckie Teki Hist. [Z.] 3: 2006 s. 537-539.

Wspomnienia o powstaniu Koła Historyków UMK w VI 1946 r.

510. OLIWIECKI Michał: Harcerstwo na ziemi elbląskiej. Cz. 1: Lata 1945-1956. Elbląg 2006 Komenda Hufca ZHP Elbląg im. Mikołaja Kopernika ss. 224, il. 
511. PACLAWSKI Ryszard: Gra o harcerstwo. Warszawa-Sanok 2005 Paleta-Art R. Paszkowski; Stow. Wychowawców Eleusis ss. 257, il.

Wspomnienia naczelnika Związku Harcerstwa Polskiego z pelnienia funkcji w 1. 1990-2000.

Rec.: Kiewicz Adam, Rocz. Hist. Harcerstwa. [T.] 2: 2006 s. 98-104.

512. SACIŃSKI Wiesław Zbigniew: Piotrkowski hufiec ZHP 1945-2005. Szkic monograficzny. Piotrków Trybunalski 2006 Urząd Miasta ss. 279, il. (Biblioteka, Piotrków 800; 3).

513. SPRAWOZDANIE i historia Koła Geografów Uniwersytetu Jagiellońskiego w latach 1981-2006. Pod red. Izabeli Walczak. Kraków 2006 Koło Geografów UJ im. Ludomira Sawickiego ss. 108, il. Koło Geografów Inst. Geografii i Gospodarki Przestrzennej UJ.

Tresć: 1. Sprawozdanie z działalności Koła Geografów Uniwersytetu Jagiellońskiego w latach 1981-2006 s. 9-86; Dzieje Koła Geografów Uniwersytetu Jagiellońskiego w latach 1881-2006 s. 87-98; Wspomnienia o Kole s. 99-208.

514. STROMPOWSKA Agata: Chorągiew Lwowska. Rocz. Hist. Harcerstwa. [T.] 2: 2006 s. 25-32.

W czasie II wojny światowej.

515. SUCHMIEL Jadwiga: Polskie Stowarzyszenie Studentek Uniwersytetu Jagiellońskiego „Jedność” w Krakowie 1910-1939. Częstochowa 2005 Wydaw. Akad. im. Jana Długosza ss. 230, il.

516. SZYDŁOWSKA Ewelina: Dzieje Harcerstwa Mosińskiego 1921-2005. Mosina 2006 Urząd Miej.; Ośr. ZHP ss. 135, i1.

517. TYSZKIEWICZ Adrian: Z dziejów korporacji studenckich w międzywojennym Lwowie. Politeja. Nr 2: 2004 s. 410-424.

518. WAINGERTNER Przemysław: Ruch zetowy w Drugiej Rzeczypospolitej. Studium myśli politycznej. Łódź 2006 Wydaw. Uniw. Lódzkiego ss. 509, tabl. 2. (Rozprawy Habilitacyjne Uniwersytetu Łódzkiego).

Związek Młodzieży Polskiej „Zet”.

519. WIERZBICKI Marek: Związek Młodzieży Polskiej i jego członkowie. Studium z dziejów funkcjonowania stalinowskiej organizacji młodzieżowej. Warszawa 2006 Trio; ISP PAN ss. 489, nlb. 1. (W Krainie PRL. Ludzie, Sprawy, Problemy. Rzeczywistość PRL odczytana z akt, dokumentów, zapisów, twórczości).

Rec.: Sadowska Joanna, Studia Podl. T. 16: 2006 s. 488-493.

520. ZAKRZEWSKA Zofia: Przyczynek do historii Organizacji Harcerskiej Związku Młodzieży Polskiej - przemiany założeń ideowo-programowych i poglądów jej działaczy. Rocz. Hist. Harcerstwa. [T.] 2: 2006 s. 50-65.

Lata 50. XX w.

521. ZWIĄZEK Młodzieży Wiejskiej Rzeczypospolitej Polskiej „Wici” na ziemi garwolińskiej. W 75-lecie powstania ZWM RP i 70 rocznicę konferencji ideologiczno-programowej „Wici” w Kępie Celejowskiej. Materiały konferencji naukowej zorganizowanej 15 czerwca 2003 r. w Kępie Celejowskiej. Praca zbior. pod red. Arkadiusza Kołodziejczyka i Tadeusza Piesio. Garwolin-Warszawa 2004 Lud. Tow. Nauk.-Kult. Oddz.; Muzeum Historii Pol. Ruchu Ludowego ss. 188 , nlb. 3 , tabl. 8 , il.

Treść: Kołodziejczyk A., Piesio T.: Przedmowa s. 5-7; Gnat-Wieteska Zbigniew: Ruch ludowy w Garwolińskiem (do 1939 roku) s. 9-22; Turkowski Romuald: Powstanie i rozwój Związku Młodzieży Wiejskiej Rzeczypospolitej Polskiej „Wici” (1928-1939) s. 23-34; Gmitruk Janusz: ZMW RP 
„Wici” i ZMW - fenomen odradzania i ciagłości organizacyjnej s. 35-52; Piesio T.: Ruch młodowiejski w powiecie garwolińskim s. 53-66; Piesio T.: W 70-lecie konferencji ideologicznej w Kępie Celejowskiej s. 67-100; Lech Andrzej: Agraryzm wiciowy w latach trzydziestych XX wieku s. 101-112; Jachymek Jan: Neoagraryzm s. 113-122; Kołodziejczyk A.: Ideologia historyczna Związku Młodzieży Wiejskiej Rzeczypospolitej Polskiej „Wici” 1928-1939 s. 123-148; Waźniewski Władysław: Ludowcy w ruchu oporu powiatu garwolińskiego w latach 1939-1944 s. 149-166; Piesio T.: Działacze ludowi Ziemi Garwolińskiej s. 167-176; Boruta Tadeusz: Młodzież powiatu garwolińskiego w latach I wojny światowej s. 177-182; Matosek Mirosław: Józef Rękawek [ur. 1914] - wiciarz z Jagodnego s. 183-186.

Opracowala Anna Gruca 